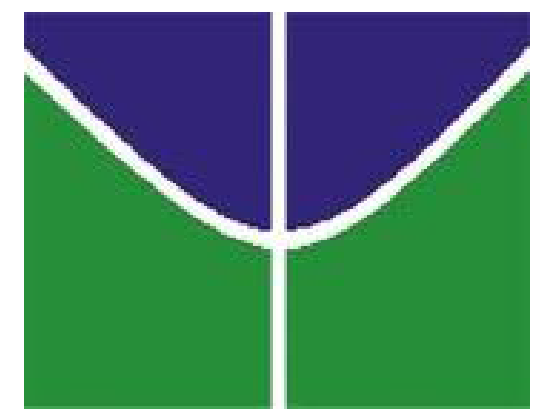

UNIVERSIDADE DE BRASÍLIA

INSTITUTO DE LETRAS

DEPARTAMENTO DE LINGUÍSTICA, PORTUGUÊS E

LÍNGUAS CLÁSSICAS

PROGRAMA DE PÓS-GRADUAÇÃO EM LINGUÍSTICA

AS RELATIVAS DE GRAU NO PORTUGUÊS BRASILEIRO:

UMA ABORDAGEM GERATIVISTA

Wagner Luiz Ribeiro dos Santos

Brasília - DF 
Wagner Luiz Ribeiro dos Santos

\section{AS RELATIVAS DE GRAU NO PORTUGUÊS BRASILEIRO: UMA ABORDAGEM GERATIVISTA}

Dissertação apresentada ao Programa de PósGraduação em Linguística, Departamento de Linguística, Português e Línguas Clássicas, Instituto de Letras, Universidade de Brasília, como requisito parcial para a obtenção do Grau de Mestre em Linguística, na área de concentração de Teoria e Análise Linguística.

Orientadora: Prof ${ }^{\mathrm{a}}$. Dr ${ }^{\mathrm{a}}$. Helena da Silva Guerra Vicente.

Brasília - DF 
Ficha catalográfica elaborada automaticamente, com os dados fornecidos pelo(a) autor(a)

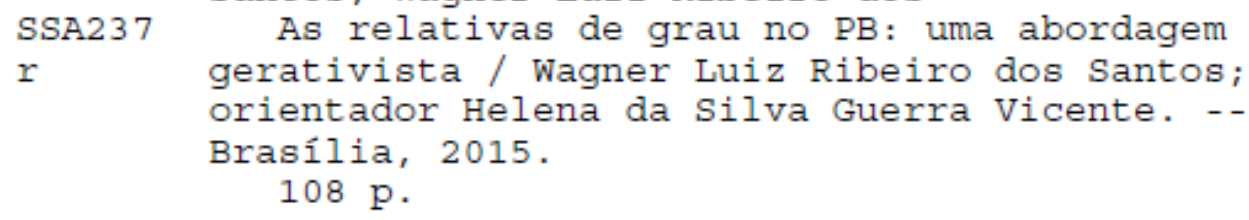

1. Orações relativas. 2. Relativas de grau. 3. Maximalização. 4. Sintagma de grau. I. Vicente, Helena da Silva Guerra, orient. II. Título. 
AS RELATIVAS DE GRAU NO PORTUGUÊS BRASILEIRO:

UMA ABORDAGEM GERATIVISTA

Wagner Luiz Ribeiro dos Santos

BANCA EXAMINADORA

$\operatorname{Prof}^{\mathrm{a}}$. Dra ${ }^{\mathrm{a}}$. Helena da Silva Guerra Vicente - UnB - presidente

Prof $^{a}$. Dr ${ }^{a}$. Rozana Reigota Naves - UnB - membro efetivo

Prof. Dr. Eduardo Kenedy Nunes Areas - UFF - membro externo

Prof. Dr. Marcus Vinícius da Silva Lunguinho - UnB - membro suplente 
A Deus, aos meus orixás, à minha mãe, Regina, e a meu pai, que, infelizmente, não teve a oportunidade de me ver terminando esta etapa da vida. A todos aqueles que, direta ou indiretamente, me auxiliaram neste trabalho, sem deixar de acreditar em mim. 


\section{Agradecimentos}

A Deus, nomeado em minha religião como Oludumare, criador e amoroso, que nunca deixa seus filhos desamparados. Aos meus orixás e guias, que me fortalecem e caminham comigo, dando-me força, humildade e vontade de sempre seguir em frente e crescer. Por me ensinarem que a tolerância e a aceitação dos outros e de mim mesmo faz parte do nosso processo de caminhada nesta terra.

Aos meus pais, Regina e Aloysio, pelo incentivo constante de persistência nos estudos. À minha mãe, obrigado por entender os momentos de ausência e suportar a saudade que nos sufoca. A meu pai, de forma especial, um agradecimento por olhar por mim diretamente do Orun. A você, pai, o meu melhor e o meu tudo. A saudade é imensa, mas a certeza do reencontro é certa.

À minha orientadora, professora doutora Helena da Silva Guerra Vicente, por acreditar em mim em muitos momentos em que eu mesmo desacreditei. Obrigado, professora, por sempre estar disponível à discussão e ao atendimento e pelo profissionalismo extremo, pela cordialidade e por ter sido, ao longo desses dois anos, ouvido para minhas lamúrias. Obrigado por todos os momentos, e sigamos, que a pesquisa é grande!

Ao corpo docente do Departamento de Pós-graduação em Linguística da Universidade de Brasília, que muito contribuiu para a minha formação, em especial às professoras Eloisa Nascimento Silva Pilati, Rozana Reigota Naves, Heloísa Maria Moreira Lima Salles e ao professor Marcus Lunguinho, pelos momentos de reflexão teórica e aprendizado que muito contribuíram para a realização deste trabalho e para minha formação profissional.

Ao querido amigo (e logo logo professor) Paulo Medeiros Júnior, pelo abertura para discussão acerca das orações relativas e pela boa vontade na indicação de materiais, incluindo o envio rápido de seu próprio material, quando solicitado.

Aos queridos "rimãos" do mestrado, filhos da mesma "Mamys", pelos momentos de discussão, pela companhia nos congressos, pelos momentos de descontração e diversão. Vocês fizeram desses dois anos, anos mais fáceis e melhores.

À querida "rimã "Bete, pela sempre imediata atenção e preocupação comigo e com o trabalho. Rimã, muito obrigado pelos olhos e ouvidos dispostos a me ler e me ouvir quando eu mais precisava. Você é a melhor rimã que eu poderia ter. 
Aos queridos amigos de PPGL, pelos bons momentos passados juntos, pelas discussões, pelas correrias de provas e trabalhos. Em especial, à "corja", unida à força no primeiro semestre e persistente na caminhada conjunta em direção à academia.

Aos irmãos de fé e a meu pai espiritual, incentivador do estudo e de tudo aquilo que nos torna melhores, por entenderem os meus momentos de ausência. A persistência de vocês em me encontrarem mostra que nossa amizade é forte e indissolúvel.

Por fim, muito obrigado aos meus chefes do Centro Educacional Sigma, unidade 910 Norte, por, desde o processo de entrada neste mestrado, terem me incentivado a seguir e aceitado as minhas ausências. Muito obrigado, Ana Dirce e Iomar, vocês são dois chefes que todos deveriam ter. E a você, Jota, pela disposição de ouvir meus problemas de pesquisa e me dar o apoio que eu precisava. 


\section{RESUMO}

Na presente pesquisa, desenvolvida à luz da gramática gerativa, analisamos as orações relativas, em seu subgrupo das relativas de grau, formado, a nosso ver, pelas relativas de quantidade e pelas relativas existenciais. As primeiras, as relativas de quantidade, são entendidas como as que apresentam leitura exclusivamente quantitativa, como em Perdemos a batalha porque não tínhamos os soldados que o inimigo tinha. Nesse exemplo, a relativa indica a leitura de totalidade dos soldados envolvidos na batalha, não apresentando um grupo específico de soldados, com leitura referencial, típica da restrição. Por sua vez, nas relativas existenciais, entendidas como as que apresentam leitura quantitativa e identificação da substância envolvida no processo de relativização, como em Eu trouxe comigo os livros que havia sobre a mesa, a leitura indicada é a de que foram trazidos todos os livros que estavam sobre a mesa, sem indicar um set de livros específico, em contraste com outros livros que havia no local. Estas duas subclasses das relativas perfazem, a nosso ver, o grupo das relativas de grau, que apresentam leitura de quantificação máxima do nome relativizado. Em tais relativas, as de grau, como entendido nos exemplos apresentados anteriormente, há leitura de maximalização do nome relativizado, indicando leitura de totalidade. Vale ressaltar que a leitura de grau, neste trabalho, é entendida como a leitura de quantificação total, máxima, do nome relativizado, não como um relação de gradação parcial, progressiva. Segundo parte da crítica, essa relação de maximalização se estabelece por meio do movimento aberto do sintagma de grau, DegP, responsável pela gradação do nome envolvido no processo de relativização. Apesar da leitura de grau, aplicada às duas subcategorias supracitadas, estas apresentam leituras distintas, como indicado, fato que nos leva à problematização acerca da relação que se estabelecerá entre o nome relativizado e o sintagma de grau. De forma geral, buscamos apresentar dados que sustentem a problematização apresentada, com duas hipóteses possíveis para a sua resolução, a serem examinadas com a continuidade de desenvolvimento desta pesquisa.

Palavras-chave: Orações relativas. Maximalização. Relativas de grau. Sintagma de grau. 


\begin{abstract}
In the present study, which is set within the framework of generative grammar, we analyze degree relative clauses as deriving from quantity and existential relatives. Degree relatives exhibit a reading of 'maximal quantification', which indicates that the head of the relative clause is quantified in a maximal fashion. For example, in the structure: We lost the battle because we did not have the soldiers they had. In this example, the relative represents all the soldiers involved in the battle, not an specific group of soldiers, with referential Reading, typical of restriction. The existential relatives, on the other hand, are those that represent quantities reading and that identify the substance involved in the process of relativization. For example: I've brought with me all the books that were on the table, meaning that all the books that were on the table were taken, and not an specific set of books, in contrast with another books in the room. These two sub-classes are part of the degree relatives, that are read as the maximalization of the relativized noun. In those example there is a maximalization reading of the noun, indicating the reading of a totalization. It is important to remember that, in this study, the degree reading is understood as the total and maximal quantity of the relativized noun, not as a progressive, partial degree. Quantity relatives exhibit a quantity reading while existential relatives exhibit a structure which indicates the existence of a head noun and a quantity reading. According to the linguistic research, this relation of maximalization is established via overt movement of the degree phrase, DegP, responsible for the maximal reading involved in the process of relativization. In spite of the degree reading, present in quantity and existential relative clauses, these two classes of relative clauses exhibit distinct readings, as mentioned above - a fact which leads us to questioning the relation established between the relativized head and the degree phrase. In general, we seek to present data which support this questioning, with two possible resolutions, to be examined with the continued of this research.
\end{abstract}

Keywords: Relatives clauses. Maximalization. Degree relatives. Degree phrase. 


\section{SUMÁRIO}

INTRODUÇÃO

\section{CAPÍTULO 1: O QUADRO TEÓRICO GERATIVO}

1.1 Introdução.

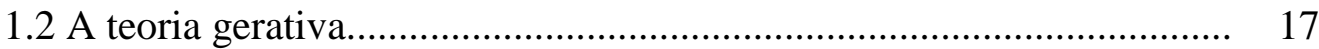

1.2.1 Os diversos modelos da teoria gerativa.................................. 22

\section{CAPÍTULO 2: A SINTAXE DAS ORAÇÕES RELATIVAS}

2.1 Introdução

2.2 Conceituação das orações relativas. 32

$2.3 \mathrm{O}$ modelo tradicional de derivação: Wh-movement. 36

2.4 O modelo Raising: em competição com o tradicional. 41

2.4.1 O Axioma de Correspondência Linear (LCA).. 46

2.4.2 A forte relação estabelecida entre D e CP. 48

2.4.3 Uso de expressões idiomáticas 50

2.5 Conclusões parciais.

\section{CAPÍTULO 3: AS RELATIVAS DE GRAU}

3.1 Introdução.

3.2 A subdivisão das Orações Relativas. 53

3.2.1 As relativas de quantidade...... 54

3.2.2 As relativas existenciais (REx) 61

3.2.3 Contraste entre as RdQ e as REx......................................... 66

3.3 As Orações Relativas de Grau.......................................................... 67

3.4 Conclusões Parciais.................................................................... 70

\section{CAPÍTULO 4: A SEMÂNTICA DAS RELATIVAS}

4.1 Introdução.

4.2 A classificação semântica tradicional............................................... 72

4.2.1 As relativas restritivas........................................................ 72

4.2.2 Orações relativas apositivas/explicativas............................. 75

4.2.3 Diferença entre as relativas restritivas e as apositivas............ 78 
4.3 As relativas maximalizadoras: a terceira possibilidade de leitura........ 79

4.4 Conclusões parciais............................................................................... 90

CAPÍTULO 5: CONSIDERAÇÕES FINAIS E PERSPECTIVAS DE UMA ANÁLISE SINTÁTICA PARA AS RELATIVAS DE GRAU.............................. 93

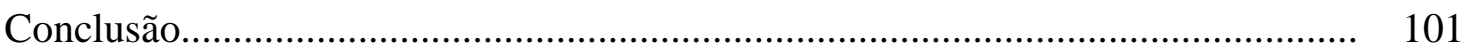

Referências Bibliográficas............................................................................ 104 


\section{INTRODUÇÃO}

As orações relativas formam um campo extenso e extremamente interessante para a Linguística e, por isso, vêm sendo estudadas por meio de análises sintáticas ou semânticas. Tais orações são consideradas um predicado que modifica um DP - do inglês Determiner Phrase, um sintagma que apresenta como núcleo um determinante, e, usualmente como complemento desse núcleo, um sintagma nominal NP -, estabelecendo relação com a oração matriz. Na maior parte das vezes, ao menos em português, a relação com a oração matriz é feita por meio de um pronome relativo, que compartilha informações e traços entre as duas orações.

Tais orações são vistas por parte dos estudiosos como uma adjunção à oração matriz (Chomsky, 1977; Aoun e Li, 2001), enquanto outros estudiosos as interpretam como complementos do DP que apresenta o nome relativizado (Kayne, 1994; Bianchi, 1999; De Vries, 2002). Dessa forma, a construção das relativas é encontrada em vários trabalhos que tratam das mais diversas características desse tipo de oração, tais como a definição do nome relativizado ou sua ausência, fenômeno comum em línguas como o inglês; a correlação entre o nome, o pronome relativo e a elipse; bem como um vasto número de características desse fenômeno linguístico.

No caso da teoria gerativa e da psicolinguística, as orações relativas despertam grande interesse com relação à sua aquisição. Como exemplos disso, temos trabalhos como os de Da Matta (1999), que analisa a dificuldade das crianças no processo aquisitivo das estratégias de relativização, Perroni (2001), que acompanha o processo de aquisição das relativas de duas crianças com idades entre três e cinco anos, e Corrêa et al. (2012), que analisam a relação entre a relativa e as anáforas envolvidas no processo de relativização na aquisição das relativas pelas crianças.

Tamanho interesse pode ser explicado, segundo Kenedy (2014), pelo fato de as construções relativas constituírem um fenômeno altamente produtivo nas línguas naturais. A partir disso, percebe-se a existência de um extenso campo de pesquisa para esse tipo de construção, seja em sua forma tida como mais comum, "as relativas com cabeça", seja em sua forma livre, as chamadas "relativas sem cabeça" ou simplesmente "relativas livres". Para Chomsky (1995 apud Kenedy, 2014), We still have no good theory for such simple matters as 
relative clauses, ${ }^{1}$ o que deixaria o campo aberto a novas propostas de análise que busquem completar a lacuna existente.

No Brasil, atualmente, há duas linhas de pesquisa que dominam os trabalhos apresentados, tanto no âmbito da linguística gerativa quanto no âmbito das demais correntes de análise: (i) a análise das estratégias de relativização, principalmente com a análise do uso da preposição quando exigida (Tarallo, 1983; Kenedy 2002, 2007); e (ii) a análise das relativas livres, que ocorrem sem a realização fonética do nome relativizado (Marchesan, 2008, 2012; Medeiros Júnior, 2005, 2014). Essas últimas vêm constituindo, principalmente na teoria linguística gerativa, o campo mais explorado de estudo das relativas no português brasileiro. Como dissemos acima, temos duas formas de relativas: as relativas "com cabeça", ou seja, aquelas que apresentam expresso o Nome $(\mathrm{N})$ modificado, alvo desta pesquisa; e as "relativas livres", ou "sem cabeça". Nos exemplos (1) e (2), temos representações dos dois tipos de relativas.

(1) a. Os alunos fizeram o exercício [que o professor propôs ec].

b. A pessoa [de quem eu gosto $e c$ ] não me dá bola

c. A fazenda [onde nasci $e c$ ] foi vendida ontem.

(2) a. Eu buscava [quem me desse valor].

b. Eu encontrei [o que precisava para a tarefa].

Nos exemplos encontrados em (1), é possível perceber que a construção das relativas aparece com o nome relativizado, enquanto, nos exemplos em (2), temos as chamadas orações relativas livres, que não apresentam os nomes relativizados explicitados no enunciado e vêm suscitando uma série de postulações e formas de análise que buscam resolver a relação com a matriz. Mais à frente, nesta dissertação, aprofundarei os dois tipos de relativas, visto que, como dito anteriormente, o material desta pesquisa é a relativa com cabeça, fazendo-se necessário apresentar o contraste em relação às relativas livres.

Quanto à semântica, que é parte muito importante desta dissertação, as relativas com cabeça são classificadas, pela linguística em geral, de duas formas distintas: as "relativas restritivas", que apresentam uma leitura de especificação do nome relativizado, construindose, na escrita, sem vírgulas na ligação com o nome-cabeça; e as "relativas apositivas/explicativas/não-restritivas”, que representam um comentário acerca do nome

\footnotetext{
1،Ainda não temos uma boa teoria sintática para os problemas simples das orações relativas” (tradução livre).
} 
relativizado, separadas desse nome, na escrita, por meio de vírgulas, pausa necessária, na prosódia, para trazer, à relação com a matriz, a noção de explicação/comentário tão necessária à semântica dessas orações. As duas realizações semânticas podem ser encontradas nos exemplos (3) e (4), a seguir. Em ambos, as relativas são construídas com cabeça, visto que, como dito anteriormente, apresentam o nome relativizado realizado na oração matriz.

(3) A professora conversou com os alunos [que ec fizeram o teste substitutivo].

(4) A professora conversou com os alunos, [que ec fizeram a prova apressadamente].

No exemplo (3), é possível identificarmos uma oração relativa restritiva, cuja interpretação leva em conta parte do nome relativizado. Isso equivale a dizer que, no universo do discurso - a parte do discurso que é verbalizada, englobando a forma como ela o é - que deve ser levado em conta para a interpretação da relativa, temos um grupo de alunos, do qual se destacam, por meio da relativa, aqueles que fizeram a prova substitutiva. No caso de (4), percebe-se a existência de uma relativa apositiva, visto que, mais uma vez, no universo do discurso, os dois conjuntos coincidem, indicando que todos os alunos indicados na oração matriz fizeram a prova apressadamente.

Neste trabalho, apresentaremos, dentre outras questões, uma problematização acerca da classificação semântica tradicional, que separa as relativas nos dois tipos descritos acima, as restritivas e as apositivas. A partir da relação estabelecida entre o nome cabeça e a oração relativa, postulamos que há, seguindo Grosu \& Landman (1998), Grosu (2002), De Vries (2002) e Szczegielniak (2012), uma terceira classificação não prevista pela tradição linguística: a classificação "maximalizadora", que pode ser encontrada na relação estabelecida em (5). Tal classificação seria aplicada a um tipo específico de relativa, as chamadas "relativas de grau".

(5) O professor trouxe consigo as três provas [que ec estavam sobre a mesa].

No exemplo (5), é possível compreendermos que a relativa apresenta noção de grau máximo com relação ao DP relativizado, no caso [as três provas], indicando que não há dois conjuntos distintos, entre os quais ocorre uma intersecção, mas que houve a leitura de quantidade total de provas colocadas sobre a mesa. Tais relativas apresentam não uma leitura de comparação de grau do nome relativizado, mas sempre apresentam uma leitura de 
totalidade, indicando, como dito anteriormente, a maximalização do nome envolvido no processo de relativização. É o que se pode perceber, também, no exemplo (6), a seguir.

(6) Eu trouxe comigo os três livros [que havia ec sobre a mesa].

Em (6), a oração relativa [que havia sobre a mesa] apresenta a leitura de que todos os três livros que existiam na mesa foram trazidos. Assim, a leitura apresentada não dá conta de que existiam outros livros sobre a mesa, no universo do discurso, mas que havia somente três e que todos foram trazidos. Assim, tem-se a compreensão maximalizadora do nome relativizado.

Vale ressaltar, a princípio, que a noção de relativas de grau utilizada neste trabalho é a de que há uma leitura de grau máximo do nome envolvido no processo de relativização, como dito anteriormente. Compreendemos, a partir disso, que a ocorrência desse tipo de relativa apresentará, sempre, a leitura de completude, de maximalização do nome relativizado, não uma leitura gradual deste nome.

A partir disso, entendemos, para defender o ponto de vista aqui tratado, que as relativas de grau subdividem-se em dois tipos: as relativas de quantidade, em que se identificam as quantidades envolvidas no nome relativizado, e as relativas existenciais, que apresentam uma noção de existência pela presença de verbos chamados existenciais. É interessante notar que, em português brasileiro - PB -, poucos são os trabalhos, como o de Valer (2008), que tratam, ainda que superficialmente, a relação semântica desse tipo de oração em específico.

Nesse contexto, as relativas existenciais são aquelas que apresentam uma leitura dupla com relação ao nome relativizado. Tal leitura dupla explica-se como a leitura de quantificação do nome-cabeça, assim como a leitura que atesta sua existência, no universo do discurso, como apresentado no exemplo (7), a seguir.

(7) O professor corrigiu as provas [que havia ec no pacote].

No exemplo (7), temos a leitura de que todas as provas que estavam no pacote foram corrigidas pelo professor, apresentando uma leitura de quantificação máxima, como defendido nesta dissertação, bem como a relação existencial de que o que havia no pacote corrigido pelo 
professor eram provas e não exercícios, por exemplo. As relativas existenciais, assim como dito anteriormente, apresentam poucos estudos, tanto em português quanto em inglês, carecendo de maior descrição e análise.

O segundo subgrupo das relativas, a de quantidade, apresentam, assim como as existenciais, uma leitura de quantificação máxima do nome relativizado, não apresentando, entretanto, uma leitura de existência, típica do primeiro subgrupo aqui apresentado. Dessa forma, a relativa apresenta a quantificação do nome relativizado. É o que pode ser percebido no exemplo (8), retirado de Móia (2013).

(8) Perdemos a batalha porque não tínhamos, nem de perto nem de longe, os soldados [que o inimigo tinha $e c]$.

Em (8), temos uma leitura específica de quantificação, visto que o verbo envolvido na relativa [que o inimigo tinha] não apresenta leitura existencial, necessária à compreensão de relativa existencial, apresentada anteriormente. Dessa forma, a leitura apresentada pela relativa pode ser compreendida como uma leitura de quantificação máxima, numérica, do nome relativizado [os soldados].

Conforme apresentaremos no decorrer desta dissertação, a relação de maximalização, encontrada nos exemplos de (5) a (8), seria explicada pela relação estabelecida entre o sintagma de grau - DegP - e o nome relativizado. Assim, o problema desta pesquisa diz respeito à forma pela qual esse DegP se relacionará com o nome, apresentando a possibilidade de construção de duas leituras distintas, ligadas, somente pela noção de quantificação máxima do nome relativizado. Ou seja, por que temos duas classes de relativas, as de quantidade e as existenciais, que apresentam leituras diferentes, ainda que perfazendo a classe das relativas de grau? A diferença de leitura seria determinada pelo local em que o sintagma de grau é mergido no processo de derivação? Ou há diferença na predicação entre os verbos das relativas de quantidade e das existenciais que permita a diferença de leitura? Essas hipóteses serão apenas discutidas de forma preliminar, visto que a busca pela resolução do problema direcionará a continuidade desta pesquisa.

Para discutir o fenômeno em questão, esta dissertação apresenta a seguinte divisão: esta pequena introdução, que busca apresentar os objetivos desta pesquisa e uma pequena contextualização sobre as relativas, a ser aprofundada posteriormente. Em seguida, no primeiro capítulo, são apresentados um pequeno histórico da gramática gerativa, teoria 
linguística base de nossa pesquisa, e alguns conceitos importantes para o desenvolvimento deste trabalho.

No segundo capítulo, por sua vez, apresentamos as duas mais importantes teorias de formalização da derivação das cláusulas relativas: a primeira, proposta por Chomsky, em 1977, no texto seminal On Wh-movement, e a segunda, defendida por Kayne (1994), chamada de Raising. A apresentação da visão gramatical das relativas busca suprir a necessidade de compreensão sintática que servirá como base para a análise semântica.

No terceiro capítulo, são apresentados os dois subtipos que entendemos pertencerem à classificação de relativas de grau, quais sejam, as relativas de quantidade e as existenciais, que apresentam características que as aproximam, permitindo a classificação de ambas como relativas de grau. A análise dessas duas formas de relativas é importante para a compreensão das leituras semânticas distintas que são atribuídas aos nomes relativizados, tendo as de quantidade a leitura exclusiva de quantificação do nome, enquanto as existenciais apresentam leitura de quantificação com relação ao nome relativizado, ao mesmo tempo em que apontam, como informação essencial, a existência, por meio da identificação da substância envolvida, do nome-cabeça. Nesse mesmo capítulo, apresentamos a análise dessas duas classificações de orações relativas colocando-as como relativas de grau, com uma leitura específica, a de maximalização.

Por sua vez, no quarto capítulo, apresentamos uma análise da semântica das orações relativas, apresentando as leituras tradicionais - restritivas e apositivas - e uma comparação entre essas duas formas semânticas de classificação. Além disso, apresentamos a análise da classificação maximalizadora, leitura que não é comum na tradição linguística, mas que atende à necessidade de leitura das relativas de grau, aqui apresentadas.

O último capítulo desta dissertação, o capítulo cinco, retoma a problematização apresentada ao longo dos demais capítulos, tratando da questão que diz respeito às leituras diferentes atribuídas às duas subclasses das relativas, as de quantidade e as existenciais. Nesse capítulo, apresentamos a discussão, levantando hipóteses acerca do comportamento sintático dessas duas orações. Por fim, apresentamos a conclusão desta dissertação, na qual fazemos um pequeno resumo da discussão apresentada. 


\section{CAPÍTULO 1 \\ O QUADRO TEÓRICO GERATIVO}

\subsection{Introdução}

O primeiro capítulo desta dissertação apresenta os pressupostos teóricos utilizados na construção do pensamento gerativista, norteador da análise aqui proposta. Para tanto, em um primeiro momento, apresentam-se as origens da chamada Linguística Gerativa, bem como seu aparato científico e conceitual, com destaque às modificações trazidas por ela para a análise da linguagem de forma ampla.

Em seguida, mostram-se, ainda que rapidamente, as fases pelas quais o gerativismo passou no decorrer desses quase 60 anos de existência, enfatizando a fase atual, o chamado "Programa Minimalista", pensamento desenvolvido nos últimos 20 anos, dentro do modelo de Princípios \& Parâmetros (P\&P), que apresentou uma nova maneira de olhar para a aquisição e o processamento da linguagem.

De forma rápida, para situar aquilo que trataremos nesse capítulo, temos que, segundo o P\&P, base para o pensamento gerativista, a linguagem humana é um órgão do cérebro/mente, determinado geneticamente e comum a todos os seres humanos. Tal órgão, chamado "faculdade da linguagem", contém Princípios, comuns a todas as línguas, e Parâmetros, referentes às idiossincrasias de cada uma delas.

\subsection{A teoria gerativa}

A linguagem sempre foi um dos fenômenos que mais despertaram a curiosidade daqueles que se propunham, no decorrer dos anos, a entender o funcionamento da linguagem humana. Apesar de não terem se dedicado, pelo menos no início, à compreensão desse fenômeno, os primeiros estudiosos da língua buscavam entender o "bom uso" da linguagem, e, por que não dizer, seu funcionamento de uma forma mais geral. Tal interesse surge quase paralelamente ao surgimento da Filosofia na Grécia antiga e permanece até os dias de hoje, com preocupações comuns e diversas daquelas da antiguidade clássica.

A possibilidade de uso da linguagem por todos os seres humanos, utilizando a linguagem verbal, excetuados aqueles que apresentam problemas patológicos graves, intrigou, 
no decorrer dos séculos, os pensadores da linguagem, bem como os que se dedicavam ao estudo da biologia e da filosofia. É por isso que, na década de 50, um jovem estudante da Universidade da Pensilvânia, de nome Noam Chomsky, decidiu dedicar-se a entender como a linguagem funcionava no cérebro/mente do ser humano.

Para Chomsky, esses estudos estariam filiados a uma corrente de análise linguística iniciada com a publicação da Gramática de Port-Royal, em 1660, seminal na corrente de estudos da filosofia da linguagem. Ainda para o autor, os estudos acerca do funcionamento mentalista da linguagem feitos por ele estariam inseridos em uma segunda "revolução cognitiva”, que seria continuação dos estudos de Descartes, com sua filosofia racionalista, do século XVII, e de Humboldt, no século XIX.

Segundo o autor, o estudo da língua deve passar "do estudo do comportamento e de seus produtos (textos, por exemplo) para os mecanismos internos usados pelo pensamento e pela ação humana" (Chomsky, 1998, p. 21). Nesse momento, o estudo do comportamento começa a dar lugar ao estudo dos mecanismos geradores da linguagem, buscando, para ela, uma relação genética. Para o autor,

a linguagem humana parece estar biologicamente isolada em suas propriedades essenciais e ser um desenvolvimento recente sob uma perspectiva evolucionista. Não há hoje razão séria para se desafiar a visão cartesiana de que a habilidade de usar signos linguísticos para expressar pensamentos formados livremente marque a verdadeira distinção entre o homem e o animal, ou a máquina (Chomsky, 1998, p. 18).

Muito desse interesse é fruto da percepção de que a linguagem humana, em que se insere o uso comunicativo, é um processo extremamente complexo e cheio de operações complicadas, exclusivas dos seres humanos. Segundo Kenedy (2013, p. 13), “embora raramente tenhamos consciência disso, a pessoa que produz frases e discursos envolve-se numa tarefa psicológica extremamente complexa" (grifos do autor). Essa capacidade linguística tão complexa é o objeto que a gerativa propõe-se a analisar. Para Chomsky (2006),

o interesse pela natureza e pelas origens da "maravilhosa invenção" (a capacidade comunicativa, na visão de Galileu) leva à investigação do componente do cérebro humano que é responsável por essas conquistas únicas e admiráveis. Esse órgão da linguagem, ou "faculdade da linguagem", como podemos chamá-la, é uma posse humana comum, pouco variando de um extremo ao outro da espécie, com exceção de patologias muito sérias (p. 55-56).

Ainda para o autor, a linguagem verbal deve ser entendida como o salto evolutivo que possibilitou ao ser humano chegar à posição que ocupa no mundo, alcançando conquistas e 
evolução, e permitindo que o ser humano tivesse uma história e uma cultura. Segundo Chomsky,

\begin{abstract}
A faculdade da linguagem entra de maneira decisiva em cada aspecto da vida, do pensamento e da interação humana. Ela é a grande responsável pelo fato de apenas no mundo biológico os humanos terem uma história, uma evolução cultural e uma diversidade muito complexa e rica, e até mesmo um sucesso biológico, no sentido técnico da enormidade de seus números (Chomsky, 2005, p. 30).
\end{abstract}

Diante de tamanha complexidade e interesses ainda desconexos, Chomsky busca maneiras de compreender o funcionamento da linguagem dentro da mente do ser humano, tirando o foco da utilização e contextualização da língua, e colocando-o no nascimento da linguagem que seria externalizada. Para alcançar seu intento, Chomsky precisou criar uma nova forma de olhar e analisar o mecanismo que envolve a linguagem. Vale ressaltar que, apesar de reconhecer o uso óbvio da linguagem como meio de comunicação, entre outros usos, a proposta de Chomsky foca-se no estudo da linguagem como um órgão interno ao ser humano, bem como no estudo de sua origem e de seu funcionamento.

Sua criação, a linguística gerativa, ou simplesmente gerativismo, coloca a capacidade humana de comunicar-se por meio da linguagem - principalmente em sua forma verbal como fenômeno da cognição do ser humano, em contato com outros sistemas que lhe dão suporte e funcionam como base de apoio e interface para o ato comunicativo. Assim, a capacidade linguística do ser humano não é mais vista como uma capacidade adquirida a partir dos hábitos que viriam a converter-se em comportamento linguístico de um falante, como pensavam os linguistas de origem behaviorista, como Skinner (1957), para os quais o fenômeno linguístico era externo ao ser humano.

Para Chomsky, o papel do gerativismo é descrever, para o mundo da linguística, o funcionamento dessa capacidade, bem como sua natureza. Trata-se de uma visão internalista da linguagem, que busca os pressupostos que justifiquem os acontecimentos linguísticos a partir da geração da linguagem no cérebro/mente do falante. Essa proposta - de cunho internalista - é entendida como a busca da compreensão da faculdade da linguagem em si, levando em conta o seu estado inicial e o estado que apresenta a partir do contato com a experiência. Nas palavras de Chomsky (1998, p. 37), “a gramática gerativa procura descobrir os mecanismos que são usados, contribuindo, assim, para o estudo de como são usados de maneira criativa na vida normal".

Em meio a esse contexto, era necessário que o objeto de estudo fosse comum a todos os falantes, independente da nacionalidade e, claro, da língua que falassem. Por isso, 
Chomsky escolhe, como objeto de estudo da linguística gerativa, "a língua natural”, ou, melhor dizendo, "as línguas naturais", com suas semelhanças e diferenças. Para o autor, "as propriedades das línguas particulares e da faculdade geral são inconscientemente pressupostas por toda parte, sem serem reconhecidas nem serem expressas" (Chomsky, 1998, p. 22).

A capacidade linguística do ser humano é entendida, então, como sendo inata a todo espécime humano, representada por uma área de nosso cérebro/mente capaz de gerar, a partir de dados limitados, o "léxico", uma quantidade ilimitada de sentenças, quase sempre inéditas e particulares.

Tais sentenças são geradas, na visão da gramática gerativa, por meio de um sistema computacional que aplica operações lógicas na união dos dados, transformando-os em sentenças compreensíveis e passíveis de externalização. A esse princípio de criação e interpretação infinito de novas sentenças, Chomsky nomeou "criatividade", uma das características mais importantes da linguagem humana, se não a mais importante.

A partir da proposta "mentalista" de estudo da linguagem, essa passa a ser vista como uma capacidade que não apresenta par entre os outros seres vivos, talvez se aproximando, por analogia, à de alguns insetos, com uma distância de milhões de anos na evolução, sendo, na visão de Chomsky (1998, 2005), impossível refutar que se está diante da característica distintiva entre o ser humano e os demais seres vivos. Tal capacidade recebe o nome de "Faculdade da Linguagem", um órgão interno à mente/cérebro e que se comporta como os demais órgãos do ser humano. Nas palavras de Chomsky,

\footnotetext{
é razoável considerar a faculdade da linguagem como um "órgão da linguagem", no sentido em que os cientistas falam de um sistema visual ou sistema imunológico ou sistema circulatório como órgãos do corpo. Compreendido desse modo, um órgão não é algo que possa ser removido do corpo, deixando o resto intacto. É um subsistema de uma estrutura mais complexa (1998, p. 19).
}

Alguns fatos parecem sustentar a visão de que o ser humano é biologicamente programado para usar a linguagem, baseada na propriedade elementar da "infinitude discreta", que não é ensinada às crianças no processo cognitivo de apreensão da linguagem ou processos similares. Como explicar, se não pela constituição genética, que é possível construírem-se sentenças com um número ilimitado de elementos? A explicação mais óbvia é a de que essa predisposição é passada por meio dos genes, por meio da codificação genética humana, pois "pressupomos ainda que o órgão da linguagem é como outros, no sentido de que seu caráter básico é uma expressão dos genes" (Chomsky, 1998, p. 19), ainda que não seja possível, no momento, determinar-se o gene - ou genes - responsável por isso. 
Apesar disso, é possível, partindo-se do pressuposto de que a faculdade da linguagem é um aparato genético, estudar o estado inicial dessa capacidade da linguagem e seu desenvolvimento, que se dá a partir da relação entre a capacidade inata e a experiência, trazida pelos estímulos externos de uma dada língua natural, a qual se tornará, pela "moldagem" da GU - Gramática Universal, estágio inicial da Faculdade da Linguagem -, a língua materna da criança. Para o linguista,

podemos investigar de outras maneiras o "estado inicial", geneticamente determinado, da faculdade da linguagem. Evidentemente, cada língua é resultado da atuação recíproca de dois fatores: o estado inicial e o curso da experiência. Podemos imaginar o estado inicial como um "dispositivo de aquisição de língua" que toma a experiência como "dado de entrada" e fornece a língua como um "dado de saída" "um dado de saída" que é internamente representado na mente/cérebro (Chomsky, 1998, p. 19).

Vale ressaltar que os estímulos externos, entendidos como sendo os "dados de entrada", não são suficientes para definir a língua do falante por si só, pois acontecem de forma pobre, inconsistente. É o que a linguística gerativa chama de "Argumento da pobreza de estímulo", desenvolvido a partir do conhecido "Problema de Platão", da filosofia grega clássica. Aqui, de um ponto de vista gerativo, os dados externos são encarados somente como estímulos que formatarão, apresentando aquela que será a língua materna do falante, a capacidade inata da linguagem, não funcionando como dados a serem imitados e reproduzidos a partir de certos estímulos, como pensavam os behavioristas. Acerca da importância dos dados e da aquisição da linguagem, o principal teórico do gerativismo afirma:

Por outro lado, ao mesmo tempo, pela primeira vez realmente foi feito um esforço
para tratar o que posteriormente veio a ser chamado de problema lógico da aquisição
de língua. Obviamente, as crianças que adquirem esse conhecimento não têm muitos
dados. Podemos, de fato, estimar de modo bem aproximado o total de dados que elas
têm, e ele é muito limitado; ainda assim, as crianças, de algum modo, atingem esses
estados de conhecimento que têm aparentemente grande complexidade,
diferenciação e diversidade - e isso não pode ser. Cada criança é capaz de atingir
qualquer um desses estados. Elas não são especialmente configuradas para um ou
para outro, portanto a estrutura básica da linguagem deve ser essencialmente interna
e vir de dentro, não de fora (Chomsky, 2006, p. 114).

Esses dados externos, entendidos, como dito anteriormente, como estímulos, são o input necessário para que a faculdade da linguagem produza a própria linguagem como output, o qual é, segundo Chomsky (2005), internamente representado na mente/cérebro. São exatamente os estímulos e o produto da linguagem os "atores" passíveis de análise para a gerativa, que busca entender o funcionamento da língua a partir da relação existente entre estímulos e produto. O produto internalizado dessa, ou as estruturas formadas pelo processo 
descrito pelo gerativismo, é chamado de "Língua-I", que tem como contraparte a "Língua-E", ou seja, a externalização das estruturas formadas. Segundo Chomsky (2005, p. 64), "esse procedimento (o procedimento gerativo que forma as descrições estruturais) pode ser chamado de "Língua-I", um termo para indicar que essa concepção de linguagem é interna, individual e intensional".

Parece claro que a simples formulação da ideia de que existe uma faculdade responsável pela produção de linguagem no ser humano não era suficiente para resolver todo o problema da linguística, em especial o da gerativa. Era necessário, então, que se desenvolvessem descrições capazes de explicar a produção linguística na pluralidade de línguas produzidas por um mesmo aparato genético. Para tanto, os linguistas gerativos buscam analisar seu objeto de estudo a partir de uma forma matemática e lógica, aplicável a todas as línguas naturais.

Como ponto de partida da análise, tem-se a ideia de "competência linguística" que, segundo Kenedy (2013), é o conhecimento interno e tácito que todo falante nativo tem das regras de formação de sentenças em sua língua. A competência não deve ser entendida como o uso da linguagem como método comunicativo, mas como a capacidade de formar sentenças em determinada língua natural. Vale lembrar que essas sentenças, formadas e compreendidas de forma infinita em uma determinada língua natural, correspondem ao que Chomsky chamou de "criatividade", característica essencial da "faculdade da linguagem". Ao uso concreto da língua, dá-se o nome de "desempenho linguístico", que, apesar de não ser o centro de estudo da linguística gerativa, apresenta-se como o repositório de corpus a ser analisado por ela. $\mathrm{O}$ desempenho, por ser a concretização do uso, envolve vários outros sistemas e habilidades do ser humano, tais como a memória, a intencionalidade, seu conhecimento de mundo, entre tantos outros.

A seguir, para embasar de forma mais clara o pensamento gerativo, desenvolvido, como vimos, por Chomsky nos últimos quase 60 anos, apresentamos um pequeno histórico dos momentos pelos quais passou a linguística gerativa da década de 50, quando foi criada, até o momento atual.

\subsubsection{Os diversos modelos da teoria gerativa}

Como era de se esperar de qualquer teoria científica, ainda mais de uma proposta tão inovadora quanto a apresentada por Chomsky na década de 50, a teoria gerativa passou por 
diversos modelos e construções teóricas até chegar aos dias de hoje. Percebe-se, no histórico do gerativismo, que a evolução na forma de análise e tratamento da linguagem se dá de forma continuada, levando-se em consideração os momentos anteriores de pesquisa dentro da linguística gerativa. Nesta subseção, pretendemos apresentar um pequeno histórico do desenvolvimento da gramática gerativa, baseada nos textos do próprio Chomsky $(1965 ; 1972$; 1981; 1995; 1998; 2001; 2005), Kato (1997), Kenedy (2008, 2013), Borges Neto (2005), entre outros.

A continuidade de pensamento da gramática gerativa é possível, pois, como afirma Borges Neto (2005), a Gramática Gerativa é um "programa de investigação científica", que se fundamenta sobre um núcleo e uma heurística. $\mathrm{O}$ autor entende que o núcleo de um programa de investigação são as proposições metafísicas que orientam a investigação, possível de ser entendida como o objetivo geral dessa forma de investigação. Por sua vez, a heurística, segundo Borges Neto (2005, p. 95), “é um conjunto de regras metodológicas que nos dizem que direções devem ser seguidas na busca das ‘implicações' científicas”.

Dessa forma, para Borges Neto (2005, p. 96-97), entende-se que a linguística gerativa tem como núcleo o entendimento dos comportamentos linguísticos como, "ao menos parcialmente, determinados por estados da natureza/cérebro" e "a natureza dos estados da mente/cérebro, parcialmente responsáveis pelo comportamento linguístico.”

A partir disso, o Borges Neto (2005) postula que a heurística da linguística gerativa, entendida como programa, está na

criação de sistemas computacionais que sirvam de modelo para o conhecimento linguístico dos falantes/ouvintes de uma língua. Esses sistemas computacionais devem ser entendidos como hipóteses explicativas e suas consequências empíricas devem ser avaliadas num sistema dedutivo (Borges Neto, 2005, p. 97).

Dessa forma, é possível entender que as modificações dentro da teoria são motivadas pelo mesmo núcleo, perseguido por Chomsky, na visão de Borges Neto (2005), nos últimos 50 anos, agora 60, de desenvolvimento da gramática gerativa. Para o autor, essa manutenção de foco, tendo o objetivo principal sempre em vista, é o que permite compreender a gramática gerativa como um programa de investigação que apresenta diferentes maneiras de alcançar tal objetivo.

O primeiro modelo de teoria gerativa, conhecido como "Teoria Padrão" ou "Gramática Transformacional", apresentava um sistema composto por diversos níveis. Tais níveis eram 
entendidos por Chomsky como a Estrutura Profunda (Deep Structure - DS), a aplicação das transformações que resultariam em uma Estrutura Superficial (Superficial Structure - SS) que era entendida como a manifestação fonético/fonológica das sentenças originadas em DS. Para Chomsky (1972, p. 45),

\begin{abstract}
a linguagem tem um aspecto interno e um aspecto externo. Uma frase pode ser estudada do ponto de vista da maneira como exprime um pensamento ou do ponto de vista de sua forma física, isto é, do ponto de vista da interpretação semântica ou da interpretação fonética. Usando uma terminologia recente, podemos distinguir a "estrutura profunda" de uma frase de sua "estrutura de superfície". A primeira é a estrutura abstrata subjacente que determina sua interpretação semântica; a última é a organização superficial de unidades que determina a interpretação fonética e se relaciona com a forma física da expressão oral real, sua forma percebida ou intencional. Nestes termos, podemos formular uma segunda conclusão fundamental da lingüística cartesiana, a saber, que as estruturas profunda e de superfície não precisam ser idênticas. A organização subjacente de uma frase, que tem importância para a interpretação semântica, não é necessariamente revelada pelo arranjo real e pelo método da expressão de seus componentes.
\end{abstract}

Surge, também, a noção de que as línguas naturais apresentariam características próprias e outras compartilhadas, como aponta o próprio Chomsky (1965, p. 86): “a gramática de uma língua particular deve ser completada por uma gramática universal que dê conta do aspecto criativo do uso da linguagem e que formule as regularidades profundas que, por serem universais, são omitidas da gramática propriamente dita”.

Haveria, então, regras que seriam as responsáveis pelas construções linguísticas, e, nessas regras, estava o foco do gerativismo. Segundo Chomsky (1965, p. 97), "uma gramática gerativa deve consistir num sistema de regras que, dum modo interativo, podem gerar um número indefinidamente grande de estruturas".

No nível da Estrutura Profunda, entraria em ação o léxico e seriam aplicadas as regras sintagmáticas, responsáveis pelas construções de enunciados. No caminho entre a DS e a SS, aconteciam as transformações, tão caras à gerativa da época. Nesse modelo, as regras interpretativas também eram aplicadas em DS, impossibilitando que modificações semânticas ocorressem durante as transformações e em SS.

Essa noção interpretativa restrita à DS mostrou-se problemática em alguns casos, principalmente em transformações que envolviam a voz passiva e os quantificadores, por exemplo, quando a posição desses últimos e sua relação com o novo "sujeito" modificava a significação original da sentença.

Buscando resolver esses problemas, Chomsky revisa, entre o final dos anos 1960 e o início da década seguinte, sua teoria inicial. A principal modificação advinda dessa revisão foi 
a possibilidade, apontada pelo linguista - com contribuição de muitos outros pensadores gerativos -, de que modificações semânticas poderiam ocorrer no "trajeto" entre DS e SS, dividindo a significação entre os níveis envolvidos. Esse pensamento seria a base para o que ficaria conhecido como "Lexicalismo" (Chomsky, 1970; Jackendoff, 1975).

No movimento de modificações apresentadas durante as décadas de 60 e 70, surge uma proposta de modelo que aproximasse a sintaxe gerativa da semântica. Como "embrião" desse pensamento, têm-se Gruber (1965) e Fillmore (1968), que começaram a dar ênfase e importância às relações temáticas entre a semântica e a sintaxe. Seguindo essa esteira, alguns linguistas gerativos propuseram que algumas características analisadas pela sintaxe, na verdade deveriam pertencer a uma análise puramente semântica, chegando, inclusive, a propor a separação dos dois níveis e a eliminação da estrutura lexical e das estruturas sintáticas propostas por Chomsky.

Nessa mesma década, a postulação de um conceito modificou e auxiliou na construção de uma nova visão, chamada muitas vezes de "Lexicalismo", como dito anteriormente, tendo como obra fundamental, escrita também por Chomsky, o livro Remarks on Nominalization, de 1970. O conceito de trace, "vestígio", em português, conseguia, a partir da noção de movimento mais sólida, remover a aplicação das regras de significação à DS, transferindo-as para SS, de forma mais definitiva. Ao postular essa mudança de posição, Chomsky conferiu maior importância à SS. Até esse momento, o estudo das línguas segmentava-se, e o sistema de regras prevalecia. Chomsky (2006, p. 114) aponta que havia, nessa época um paradoxo.

\footnotetext{
O paradoxo era que, para que se pudesse dar uma explicação descritiva precisa, parecia necessário haver uma enorme proliferação de grande variedade de sistemas de regras, regras diferentes para construções gramaticais diferentes. Por exemplo, orações relativas parecem diferentes de orações interrogativas e o SV (Sintagma Verbal) em húngaro é diferente do SN (Sintagma Nominal), e todos são diferentes do inglês. Assim, o sistema explodiu em complexidade.
}

Ao se iniciarem os anos 1980, a teoria entrou em um momento decisivo e de grandes modificações conceituais e teóricas. O modelo proposto, então, era o do Government and Binding (GB), traduzido para o português como “Teoria da Regência e Ligação". Substitui-se, nesse modelo, a noção de transformação (ou o aspecto transformacional das estruturas) pela ideia de movimento motivado por necessidades do sistema. Formalizam-se, também, os níveis Forma Fonética (Phonetic Form - PF) e Forma Lógica (Logical Form - LF). O primeiro deles, na verdade, será desmembrado da Estrutura Superficial, passando a nível 
“independente”. Já o segundo, LF, com sua postulação, passa a ser o nível no qual serão aplicadas as regras interpretativas. Segundo Mioto,

o que queremos do nosso modelo sintático organizado desta maneira é que ele dê conta do fato de que, para construirmos uma sentença, devemos recorrer ao léxico da língua (isto é, ao nosso "dicionário mental", o conjunto de palavras pertencentes à nossa língua) e, fazendo uso das informações aí presentes, construir uma primeira estrutura, DS. Na passagem de DS para SS, podemos movimentar constituintes, de tal modo que então poderemos ter o objeto direto do verbo na posição inicial da sentença. (...) É a representação da sentença em SS que será enviada para PF para ser pronunciada; é também essa representação que será enviada para LF para ser interpretada semanticamente (2007, p.28).

Uma das mudanças mais importantes, que ainda fundamentam a forma de pensar do gerativismo, foi a substituição da noção de regras aplicadas às línguas particulares pela hipótese de existência de uma Gramática Universal (GU), na qual estariam marcados Princípios e Parâmetros. O pensamento gerativista, aqui, deixava de buscar regras que explicavam os fenômenos em cada uma das línguas naturais, pela noção da existência de características aplicáveis a todas as línguas e outras, específicas, que diferenciam as línguas em suas particularidades. Na visão de Chomsky,

\footnotetext{
já na década de 50, estava claro que havia um problema e houve muitos esforços para lidar com ele. A saída óbvia foi tentar mostrar que a diversidade das regras é superficial, que você pode encontrar princípios muito gerais aos quais todas as regras aderem, e, se você abstrair esses princípios das regras e atribuí-los ao patrimônio genético da criança, então os sistemas remanescentes parecerão muito mais simples. (...) A ideia é que, se você puder fatorar as regras em condições universais e em resíduo, então o resíduo torna-se mais simples e a criança tem de adquirir apenas ele (2006, p. 114-115).
}

Os Princípios são entendidos, a partir disso, como as características universais aplicáveis a qualquer língua natural - como citado acima -, sendo invariáveis, rígidos e não violáveis. São esses, na noção da gerativa, os responsáveis pela proximidade das línguas que, como dito anteriormente, comportam-se de forma muito mais próxima do que se imaginava. Por outro lado, os Parâmetros são as características distintivas das línguas, responsáveis, então, pelas idiossincrasias linguísticas, a diversidade das línguas. São os resíduos definidos por Chomsky, na citação acima e, por isso, apesar de pertencerem à genética da criança, necessitam de uma marcação para tornarem-se efetivos, fato que ocorreria com o aprendizado de uma determinada língua natural. 
Nas palavras de Chomsky (1998, p. 39), “a abordagem de Princípios e Parâmetros se baseia na ideia de que o estado inicial da faculdade da linguagem consiste em princípios invariantes e em leque finito de escolhas quanto ao funcionamento do sistema inteiro". $\mathrm{O}$ "leque finito de escolhas" são, exatamente, os parâmetros da teoria. O modelo P\&P é uma revolução completa na forma de se ver a linguagem, sendo, inclusive, visto como uma das poucas novidades desde o início do estudo da linguagem, há mais de dois mil anos. Até o momento de desenvolvimento do modelo P\&P, a Gramática Gerativa seguia o caminho, apesar de suas abismais diferenças, das demais linhas teóricas linguísticas: a inserção de uma nova regra, sempre que um novo problema aparece. Apesar disso, Chomsky (2006) também reconhece que toda a busca pela compreensão das línguas em sua forma particular foi essencial para a compreensão que se tem, hoje, da faculdade da linguagem, visto que "isso abriu o caminho para uma enorme explosão de pesquisa em todos os tipos de áreas, (...) e, de fato, creio ser justo dizer que, nos últimos 20 anos, se aprendeu mais sobre linguagem que nos dois mil anos precedentes" (p. 117).

Dessa explosão de trabalhos, foi possível perceber, também, que as formações linguísticas mais complexas não necessitavam de uma explicação também complexa, e que princípios mais econômicos poderiam ser aplicados às relações de formação de sentenças e nas construções estudadas. Daí surge o "Programa Minimalista" (PM) da gerativa, forma de pensar que orienta a maior parte das pesquisas em linguística nos dias de hoje.

Tal programa, o PM, é definido por Chomsky não como uma teoria, mas como uma forma de orientação de pesquisa para que se chegue à teoria mais enxuta acerca da linguagem. O autor afirma que "o Programa Minimalista é um "programa”, não uma teoria, menos até do que a abordagem P\&P” (1998, p. 41). Sua principal motivação é a exclusão das construções teóricas que não sejam absolutamente naturais e necessárias, sendo "uma abordagem, uma estrutura que acelerou a busca por redundâncias que deveriam ser eliminadas, fornecendo uma nova plataforma, da qual foi possível prosseguir - com um sucesso, de fato, muito maior" (Chomsky, 2006, p. 118).

Há, com o minimalismo, portanto, a busca por uma análise que se mostre mais enxuta e, consequentemente, mais próxima da realidade da língua, que para o autor tem um projeto e um funcionamento "ótimo", sendo o minimalismo "um esforço para examinar" essa questão. Chomsky, com o PM, aprofunda, a partir de sua percepção, a relação existente entre a linguagem e outros sistemas da mente, os chamados "sistemas de interface", que garantiriam o status de perfeição da língua. De uma forma um pouco mais simples, a faculdade da 
linguagem deve atender a demandas não simplesmente comunicativas, mas sim demandas da mente, ou seja, de sistemas integrados a ela.

A faculdade da linguagem se encaixa dentro da arquitetura mais ampla da mente/cérebro. Ela interage com outros sistemas, que impõem condições que a linguagem tem de satisfazer se ela é para ser utilizável de qualquer modo que seja. Estas poderiam ser consideradas "condições de legibilidade", chamadas "condições de saída nuas" (Bare Output Conditions) na literatura técnica. Os sistemas dentro dos quais a faculdade da linguagem se encaixa têm de ser capazes de "ler" as expressões da língua e usá-las como "instruções" para o pensamento e a ação (CHOMSKY, 1998, p. 43).

No processo de economia proposto pelo PM, algumas das construções teóricas precisavam ser repensadas e, no caso da análise gerativa dos dados da língua, eliminadas. Assim, dos quatro sistemas existentes dentro da GB, a saber, Estrutura Profunda (DS), Estrutura Superficial (SS), Forma Fonológica (PF) e Forma Lógica (LF), permanecerão como estruturas do Minimalismo somente as duas últimas, pois, nas palavras de Chomsky,

\begin{abstract}
o programa minimalista exige que submetamos os pressupostos convencionais a um cuidadoso escrutínio. O mais respeitável desses pressupostos é o de que a linguagem tem som e significado. Em termos atuais, isso traduz a tese de que a faculdade da linguagem emprega outros sistemas da mente/cérebro em dois "níveis de interface", um relacionado com o som, o outro com o significado. (...) Uma questão é se há níveis que não sejam os de interface: existem níveis "internos" à linguagem, em particular os níveis de estrutura profunda e de superfície que desempenhariam um papel substancial na pesquisa moderna? O programa minimalista procura mostrar que tudo o que foi explicado até agora em termos desses níveis foi mal descrito, e é compreendido igualmente ou melhor em termos de legibilidade de interface (Chomsky, 1998, p. 45.47).
\end{abstract}

Outra modificação extremamente importante e interessante trazida pelo programa minimalista foi a modificação da visão dos itens lexicais, que agora possuem um conjunto de traços subespecificados que, para Chomsky (2001), devem ser valorados durante o processo de derivação. Vale ressaltar que, durante o desenvolvimento do Programa Minimalista, ainda em curso, há variação com relação ao sistema de valoração/checagem, como resumido, a seguir, em nota ${ }^{2}$.

\footnotetext{
${ }^{2}$ A teoria de checagem ou concordância vem sendo revisada ao longo dos anos. Conforme Chomsky (1995), a eliminação de traços não-interpretáveis ocorre via checagem por meio de movimento de traços (Attract), desencadeado por um alvo que contenha traços não-interpretáveis. Em Chomsky $(2000: 122,123)$, a noção de checagem é reformulada: não há movimento de traços, e o apagamento de traços não-interpretáveis passa a ser entendido como fruto da operação Agree. Essa operação é motivada pela combinação (matching) de uma sonda (probe) e de um alvo (goal), que devem satisfazer certas condições relacionais para que a operação seja bemsucedida. Uma característica importante desse sistema reside na possibilidade de haver concordância à distância, sem necessidade de movimento do alvo. Chomsky (2001) reformula novamente o mecanismo em questão, introduzindo a noção de "valoração". Nesse novo entendimento, a interpretabilidade dos traços é determinada no léxico pela GU: traços não-interpretáveis entrariam na derivação sem valor especificado, ao contrário dos traços
} 
Tais traços são entendidos como: (i) traços semânticos, os quais serão lidos em LF; (ii) traços fonológicos, a serem lidos em PF; e (iii) traços formais, ilegíveis aos dois sistemas de interface, mas necessários à derivação ocorrida no sistema computacional.

Essa é outra das inovações do Minimalismo, que reconhece a computação (ou sistema computacional) como parte essencial da faculdade da linguagem, sendo comum a todas as línguas do mundo. Claro que o sistema computacional não poderia exceder o princípio de economia minimalista e, por isso, um dos objetivos do programa tem sido o de tentar "mostrar que as únicas operações computacionais são aquelas que são inevitáveis sob os pressupostos mais fracos relativos às propriedades de interface" (Chomsky, 1998, p. 47).

Baseado no pensamento de otimização e economia, Chomsky (1995) postula que as operações move e merge são as essenciais ao sistema linguístico. De forma geral, a operação merge dá conta da junção de dois elementos sintáticos que formam outro elemento, passível de unir-se a outro, e assim sucessivamente. Por outro lado, a operação move é resultado das operações merge e copy e trata da possibilidade de um elemento sintático ser gerado em determinada posição de base e movido para outra, com a possível interpretação em seu local in situ.

Partindo, então, da ideia de que a linguagem deverá satisfazer o sistema perceptualarticulatório, em interface com PF; e o conceptual-intensional, em interface com LF, Chomsky lança a ideia de que, já que toda sentença precisará ser lida nesses dois sistemas de qualquer forma, há necessidade de que satisfaça, para tanto, o "Princípio de Interpretação Plena" (Full Interpretation Principle - FI). Se, ao final da computação, a sentença produzida não puder ser compreendida, não atendendo às demandas dos dois sistemas, ela deverá ser rejeitada e tida como agramatical.

Há, ainda, outra modificação bastante interessante na forma como se entendem as operações de computação aplicadas à formação de sentenças. O Minimalismo postula que as operações computacionais podem ser aplicadas em qualquer ponto da derivação, algo impensável na GB, e que a diferença entre as operações estará no fato destas serem manifestas, feitas antes de Spell-out - na chamada sintaxe aberta -, ou encobertas, feitas após Spell-out, na chamada sintaxe encoberta. Essas operações, extremamente importantes na compreensão de uma série de características sintáticas, na visão de Chomsky (1998), devem ser as mesmas, "desde os itens lexicais até a representação semântica” (p. 52). 
A partir da análise das postulações feitas durante o desenvolvimento da linguística gerativa, é possível percebermos que a linguagem apresenta uma riqueza de construção enorme. Tendo como base o pensamento gerativista, com heurística diversificada em pensamentos e formas de analisar e buscar o mesmo objetivo, intentamos analisar um dado fenômeno linguístico, a saber, as orações relativas, partindo de uma perspectiva gerativista.

Assim, apresentaremos, a partir do próximo capítulo, esse fenômeno, a partir dos pressupostos gerativos, bem como de sua análise semântica, tão importante à compreensão e análise do fenômeno investigado. A seguir, no capítulo dois, apresentamos as principais propostas relacionadas à derivação das orações relativas, a partir da teoria gerativa. 


\section{CAPÍTULO 2}

\section{A SINTAXE DAS ORAÇÕES RELATIVAS}

\subsection{Introdução}

Este capítulo tem como objetivo apresentar as análises formais das orações relativas, importantes para que compreendamos a relação sintática que esse tipo de construção, nosso objeto de estudo, estabelece dentro da arquitetura da linguagem. Esse assunto tem tomado conta das discussões acerca da estruturação das relativas desde o início dos anos 1960, com diferentes formas de apresentação das teorias e atualizações, conforme o desenvolvimento da própria linguística gerativa.

Como neste trabalho apresentaremos o início de uma discussão acerca da derivação das relativas de grau, nosso objeto de estudo, torna-se de enorme importância a compreensão do processo de derivação das relativas. Vale ressaltar que nosso objetivo é analisar as relativas de grau de um ponto de vista sintático-semântico e analisar como as derivações dessas relativas apresentam leituras semânticas diferentes. Partindo da amplitude dessa pesquisa, destaca-se que a análise introduzida nesta dissertação é preliminar, com proposta de derivação ainda em fase de desenvolvimento.

Duas visões, durante o desenvolvimento da análise desse tipo de oração e atualmente, dominam o pensamento acerca da derivação das relativas na linguística gerativa: o modelo tradicional, chamado de Wh-movement, descrito em artigo homônimo por Chomsky (1977); e o chamado modelo Raising, desenvolvido ainda na década de 60 e trazido à tona, na atualidade, por Kayne (1994), Bianchi (1999), dentre outros sintaticistas da teoria gerativa da linguagem.

Dessa forma, o capítulo está dividido da seguinte maneira: inicialmente, faço uma pequena introdução das relativas e a divisão que leva em conta a presença ou a ausência de nome realizado na relativização, com o objetivo de situar a análise que proporei neste trabalho; em seguida, apresento um breve resumo das duas mais importantes teorias acerca da sintaxe das relativas, citadas anteriormente: o modelo tido como tradicional, Wh-movement, e o modelo Raising, abordagem mais próxima da nossa análise das relativas. 


\subsection{Conceituação das orações relativas}

As orações relativas são orações encaixadas que compartilham, com a oração matriz, um constituinte, estabelecendo uma relação sintática e semântica com um DP. Para Chomsky (1977), tais orações comportam-se como verdadeiros predicados dos DPs aos quais se ligam, por meio do processo de subordinação, modificando os nomes encontrados em tal DP. Esses são chamados, na literatura linguística, de nomes relativizados ou, ainda, nomes cabeça da relativa. A ligação entre as orações relativas e os DPs que modificam se dá, normalmente, por meio de um relativizador, que, em português, é comumente classificado como pronome relativo. A discussão acerca da natureza do elemento relativizador (tema discutido principalmente em trabalhos que analisam as estratégias de relativização no português, como os de Tarallo, 1983, 1985; Kato, 1993; e Kenedy, 2002) não está no escopo desta pesquisa e, por isso, tomo-os, aqui, como pronomes relativos, genericamente.

Para De Vries (2002), os nomes relativizados são os "pivôs" de ligação entre as duas partes envolvidas na relação de relativização, a saber, a oração matriz, que encerra o DP modificado, e a própria oração relativa. Segundo Marchesan (2008), o elemento compartilhado entre as duas orações é um elemento-wh que se encontra na posição de Spec$\mathrm{CP}$, conseguindo, assim, atender à necessidade de compatibilidade entre as duas orações. A noção de compatibilidade, para a autora, está relacionada à necessidade do nome relativizado ter valorados no decorrer da derivação, como aponta Chomsky (2001), seus traços-phi e papéis temáticos tanto na matriz quanto na encaixada. Essa relação é possível de ser visualizada no exemplo (1), a seguir:

(1) Conhecemos [a menina ${ }_{\mathrm{i}}$ [ [que gap $_{\mathrm{i}}$ foi encontrada na floresta].

Em (1), não temos dificuldade de perceber que o DP [a menina] é compartilhado entre a oração matriz e a encaixada, possibilitando o entendimento do enunciado de forma completa. No caso, o nome "menina" é lido na oração matriz, em que se realiza foneticamente e desempenha a função de complemento do verbo; e é compreendido também na oração relativa, na qual funciona como sujeito da oração. A classificação dessa oração encaixada como uma relativa só pode acontecer por esta apresentar uma conexão tanto semântica quanto sintática com a oração matriz: o compartilhamento do DP entre as duas, intermediado pelo relativizador. 
Percebe-se, também, que o DP é interpretado na matriz, em que foi linearizado, e na posição marcada como $e c$, na encaixada. Segundo Marchesan (2008), a noção de encaixe da oração é bastante importante para a análise das relativas, visto que essa condição é o que permite que tais orações atuem como adjunto, na visão de Chomsky (1977) e outros linguistas, como veremos adiante; e complemento, na visão de Kayne (1994), De Vries (2002) e Bianchi (1999).

Analisando a relação que se estabelece entre as duas orações envolvidas no processo de relativização, De Vries (2002) aponta para a existência de outro fato interessante na análise proposta para as relativas, que é a aparente independência do pronome relativo, envolvido nas duas orações presentes, por meio da possibilidade de desempenho de papéis temáticos diferentes. Isto é, o papel temático desempenhado na oração relativa não precisa ser o mesmo desempenhado, pelo nome relativizado, que o pronome retoma, na oração principal. Tal problema, a forma como essa relação se estabelece, com compartilhamento de significados e de funções sintáticas, foi chamada pelo autor de problema pivô. Diante disso, é inegável que o fenômeno das relativas, como afirmado anteriormente, desperta grande interesse tanto por parte de sintaticistas quanto de semanticistas.

Para Medeiros Júnior (2014), a relativa apresenta uma relação inevitável com três posições distintas no enunciado. A partir do exemplo (2), a seguir, retirado de Medeiros Júnior (2014, p. 32), é possível compreendermos algumas relações interessantes entre os termos que formam a relação relativa-matriz.

(2) O filme [que você indicou gap] é mesmo excelente.

$\mathrm{O}$ autor argumenta que o pronome relativo "está associado à expressão $O$ filme (na matriz) e à posição mais baixa - no interior da relativa - que abriga uma categoria vazia", (2014, p. 32). A terceira posição com a qual o pronome relativo estabelece ligação é a posição que ocupa. Medeiros Júnior ainda aponta que, ao olharmos somente para a relativa, percebemos que o relativizador "não se encontra em sua posição de base, ou seja, na posição em que é interpretado" (2014, p. 32-33), reforçando que há ligação entre o pronome relativo e o gap encontrado no interior da oração relativa. Dessa forma, percebe-se que a realização das 
orações relativas é extremamente complexa, envolvendo uma série de relações sintáticas que, como era de se esperar, influenciam significativamente a interpretação em $\mathrm{LF}^{3}$.

Assim, tendo conceituado as orações relativas de forma geral, é interessante percebermos que tais orações, a princípio, são divididas em dois tipos básicos: as orações relativas com núcleo nominal (RNN), também chamadas de "relativas com cabeça", em referência ao nome relativizado; e as orações sem núcleo nominal realizado, chamadas de "relativas livres" ou "relativas sem cabeça", que vêm sendo alvo de uma série de interessantes análises e estudos no PB (como os de Mioto, 1994; Kato, 1996; Medeiros Júnior, 2005, 2014; e Marchesan, 2008, 2012), principalmente no campo de pesquisa da derivação das orações, sobremaneira na linha de pesquisa gerativa.

As primeiras orações, as relativas com núcleo nominal, são o alvo de análise deste trabalho, visto que buscaremos entender a relação de gradação entre algumas relativas, chamadas de "relativas de grau", e o nome relativizado. Segundo Marchesan (2008, p. 14), esse tipo de oração "possui um constituinte que é relativizado (chamado de núcleo nominal, $\mathrm{NP}_{\text {relativo, }}$ pivô, etc.). Esse constituinte é compartilhado pela sentença matriz e pela sentença encaixada; (...) uma relativa sempre possui um constituinte que é relativizado.”

Ainda para a autora (Marchesan, 2008, p. 17), as relativas com núcleo são assim definidas pela necessidade e dependência que estabelecem com um determinado núcleo. Essa dependência pode ser encontrada, como discutido anteriormente, pela relação de ligação entre as duas orações, fato que permite a leitura e a compatibilidade entre o relativizador, a $e c$, encontrada na encaixada, e o nome relativizado, em Spec-CP.

Essa relação, mais uma vez, pode ser encontrada no exemplo (3), a seguir.

(3) [[O aeroporto] [que ec estava em reforma] já abriu].

Em (3), é possível reconhecermos uma relativa com cabeça, visto que o DP [O aeroporto] encontra-se relativizado. Essa relação é percebida pela possibilidade que tal DP tem de desempenhar a função de sujeito do verbo [abriu], na matriz, e do verbo [estava], encontrado na relativa. Assim, segundo Marchesan (2008), percebe-se que o processo de relativização acontece no enunciado, visto que o nome cabeça desempenha função sintática

\footnotetext{
${ }^{3}$ É na Forma Lógica que, como visto no primeiro capítulo, ocorre a interpretação das informações contidas na sentença. Chomsky (1977) se preocupa bastante em explicar e explicitar determinadas regras que afetariam a compreensão das informações. Hoje, no atual estágio do Programa Minimalista, entre Spell-out e $L F$, ocorrem muitos movimentos encobertos, invisíveis a $P F$.
} 
tanto na matriz quanto na relativa, essa última representada pelo elemento-QU que introduz a relativa. Além disso, o processo de relativização se completa pela existência de um pronome relativo, o elemento-QU que introduz a encaixada, apresentando ligação e compartilhamento de características com o nome com o qual se relaciona.

Quanto à semântica dessas relativas, tradicionalmente, há duas classificações (que serão aprofundadas no quarto capítulo desta dissertação), a saber, as "restritivas" e as "apositivas", como preferem alguns linguistas, ou as "não restritivas" ou "explicativas", segundo a Norma Gramatical Brasileira - NGB. Essa classificação será determinada pela relação entre relativa e nome relativizado, analisando-se a forma como a relação se dá. Como dito anteriormente, na introdução deste trabalho, nossa proposta trabalhará com o acréscimo de uma leitura, a partir da análise unificada de dois tipos de relativas, a saber, as relativas de quantidade e as relativas existenciais, descritas no terceiro capítulo, e que busca ampliar a leitura semântica dessas orações. A leitura semântica acrescida, a maximalizadora, em que ocorre o processo de quantificação máxima do nome relativizado, será apresentada no terceiro capítulo. Vale, somente, ressaltar que a leitura de maximalização apresenta leitura de quantificação máxima do nome, sempre englobando uma noção de grau máximo do nome.

No segundo tipo de relativas, chamadas de "relativas livres", tais orações são, conforme indicam autores como Marchesan (2008, 2012) e Medeiros Júnior (2005, 2014), aquelas que não apresentam núcleo nominal realizado foneticamente, como no exemplo (4a), a seguir, retirado de Marchesan (2008, p. 21). No exemplo (4b), por sua vez, há a paráfrase, para uma relativa com cabeça, da relativa livre.
a. João comeu [o que a Maria cozinhou].
b. João comeu a comida [que a Maria cozinhou].

Em (4a), temos a realização de uma oração relativa sem um núcleo nominal, que, segundo a autora, pode ser entendido por meio do contexto, possibilitando a paráfrase em (4b). Esse tipo de relativa, para Valer (2008), é introduzido, sempre, por elementos-wh, apresentando conexão, por meio deles, entre as orações. Essa necessidade seria fruto da obrigatoriedade de compatibilidade entre as relativas e a matriz.

Quanto à semântica dessas relativas, é interessante notar que, para a maior parte dos estudiosos, tais como Grosu \& Landman (1998), Valer (2008) e Medeiros Júnior (2005 e 
2014), as relativas livres são sempre maximalizadoras, por apresentarem leitura de totalidade, quantificação, com relação ao nome que fica implícito em sua construção.

A seguir, serão analisadas as duas mais importantes teorias acerca da sintaxe das relativas, descrevendo-as para uma melhor compreensão do que será tratado neste trabalho. Tais teorias, a chamada tradicional, ou Wh- movement, proposta por Chomsky (1977), e a Raising, trazida à baila novamente por Kayne (1994), diferenciam-se pelas relações de movimento e pela forma como estabelecem ligação com o nome relativizado.

\subsection{O modelo tradicional de derivação: Wh-movement}

Antes de apresentarmos o modelo de Chomsky (1977), conhecido genericamente como "modelo tradicional" ou Wh-movement, por sua utilização constante nos estudos gerativos sobre relativas, faz-se necessário apresentar um pequeno resumo do estudo acerca das relativas na história da Gramática Gerativa. Tal resumo visa à compreensão dos caminhos tomados por cada um dos estudiosos e torna-se interessante para que percebamos a modificação e o desenvolvimento da análise sintática das relativas.

Segundo Kenedy (2014), Lees, no início da década de 1960, foi um dos primeiros estudiosos a propor uma análise, à luz da gerativa, para o fenômeno de relativização. Na visão de Lees (1960 apud Kenedy, 2014), haveria duas orações não relativas que compartilhariam um NP idêntico em seu interior. Seria esse o NP que viria a ser, posteriormente, na adjunção das duas orações, relativizado. Segundo o autor, o NP da oração que viria a funcionar como a relativa seria apagado por meio da aplicação de uma série de regras e, em seguida, a oração relativa seria adjungida à outra oração, a que ainda conteria o NP relativizado.

Ainda segundo Kenedy (2014), a formalização dessa proposta ficaria a cargo de Rosembaum, ainda durante a década de 1960. Esse autor foi o responsável pela criação da chamada "transformação relativa", que influenciaria o pensamento de Chomsky na década seguinte. Segundo Rosembaum (1969 apud Kenedy, 2014), a segunda oração "não relativa" seria adjungida à primeira e, novamente após a aplicação de uma série de regras transformacionais, o NP repetido seria transformado em um elemento-QU. Percebe-se, então, que essas primeiras postulações acerca da geração das relativas seriam a base utilizada por Chomsky para sua própria postulação.

Tal postulação teria lugar na década seguinte, a de 1970, na qual Chomsky lança sua análise mais importante sobre as relativas até o momento. No artigo seminal $O n$ Wh- 
movement, publicado em 1977, o autor postula que as relativas seriam adjunções a um NP qualquer, hoje entendido como um DP. Na formalização proposta por Chomsky, a generalização para a estrutura sintática das relativas seria a mesma que a de uma série de outras construções, dentre elas as interrogações- $w h$, e apresentariam a seguinte formalização ${ }^{4}$ :

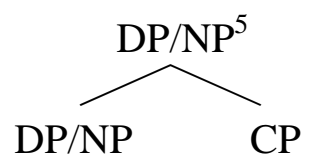

Os CPs relativos, representados acima, conteriam um elemento-wh, um pronome relativo, no caso do português, que estabeleceria uma relação de correferência com o elemento relativizado, no caso, o DP/NP da estrutura encontrada em (5). Tal elemento-QU seria gerado em posição de complemento - interno ao VP - do IP contido no CP e, de lá, seria movido para a posição de Spec-CP, como nos mostra Kenedy (2014), nas estruturas (6):
a. [DP/NP [DP/NP Alvo $\left.]_{\mathrm{i}}\left[\mathrm{CP} w h_{\mathrm{i}}\left[\mathrm{IP} \ldots t_{i} \ldots\right]\right]\right]^{6}$.
b. [DP/NP [DP/NP O menino $]_{\mathrm{i}}\left[\mathrm{CP}_{\mathrm{Cue}}\right.$ [IP $_{i}$ comeu as batatas]]].

A generalização apresentada em (6a) mostra que a relativa seria iniciada, via de regra, pelo elemento- $w h$, que, como dito anteriormente, compartilha traços morfossintáticos com o nome relativizado. Da maneira como a descrição da relativização foi proposta, ela não conseguiria abarcar tal compartilhamento, uma vez que o DP/NP alvo da relativização não contém o CP-relativo, bem como esse não contém aquele, inviabilizando a relação de ccomando entre os dois elementos. Há, portanto, uma relação de independência, causada pela visão de adjunção trazida pela postulação. Vale destacar que o nome relativizado, nas generalizações em (6), não pertence ao CP-relativo, visto este ser uma adjunção ao DP/NP da matriz. Este fato será importante para fins de comparação futura com o modelo adotado nesta pesquisa, o Raising.

\footnotetext{
${ }^{4}$ Esquema de formalização retirado de Kenedy (2014).

${ }^{5}$ A representação, por se tratar de proposição baseada em teoria de 1977, encontrada na obra On Wh-movement, apresenta, ainda, a definição de NP, que veio a ser substituída, de forma completa, pela estrutura DP nos anos 80/90, com o importante trabalho de Abney (1987).

${ }^{6} \mathrm{O}$ trace ou vestígio do elemento-QU que será movido pode ocupar diversos lugares de base, funcionando como argumento externo ou interno, complemento ou adjunto dentro da oração relativa. No caso da generalização apresentada, o trace aparece em posição meramente ilustrativa.
} 
Importante se faz destacar, neste momento, que, em On Wh-movement (1977), Chomsky postula uma generalização que abarca a maior parte das construções que incluem movimento do elemento-QU, tais como as interrogativas- $w h$, as relativas, as topicalizações, as clivadas, entre outras. Neste ponto, vale a discussão já reforçada pela literatura que adota o pensamento do modelo Raising - explicado na próxima seção - acerca da aplicação de uma mesma regra de construção para elementos diversos e distintos, tais como as relativas e as interrogativas. Esse seria, na visão de Kenedy (2003, 2014), um dos problemas mais sérios da adoção do pensamento chomskyano para a derivação das relativas, visto que a aplicação de uma mesma regra a vários tipos diferentes de orações não é interessante na busca de uma generalização para as relativas.

Hoje, há algumas hipóteses que postulam que o movimento do elemento-QU das interrogativas acontece de qualquer maneira, em sintaxe aberta nas línguas em que o elemento encabeça a interrogativa, e em sintaxe encoberta para línguas como o chinês, em que o elemento permanece in situ. Tal movimento ocorrerá de qualquer forma motivado pela força ilocutória do elemento-QU, por isso ocorrerá em sintaxe aberta ou fechada, não licenciando o não movimento. No que tange ao elemento-QU das relativas, um pronome relativo, o movimento parece ser motivado muito mais pela necessidade de ligação entre esse e o elemento (nome) relativizado. Assim, é possível entender que a motivação de movimento dos elementos-QU é diferente, o que derruba, ainda que não de forma completa, a postulação de Chomsky em 1977.

Apesar do que foi discutido acima, é certo que a generalização proposta por Chomsky (1977) foi um avanço para o estudo das construções que envolvem movimento-QU. Pode-se afirmar, então, que essa generalização não aconteceu de maneira arbitrária, baseada simplesmente nas ideias do autor sobre o assunto ao escrever o tão famoso artigo. Segundo Kenedy (2005, 2014), para Chomsky, no modelo tradicional, era possível propor tal generalização, pois todas as construções envolvidas apresentam três características comuns que contribuiriam para a proposta de uma mesma derivação, a saber, (i) apresentam uma lacuna (gap); (ii) permitem relações de longa distância; e (iii) são sensíveis às restrições de ilhas. Isso pode ser visto, segundo Kenedy (2014, p. 14), nos exemplos a seguir, retirados de Aoun e Li (2001, p. 5): 
(7) a. [NP [NP the boy $\left[\mathrm{CP}_{\mathrm{CP}} \mathrm{who}_{\mathrm{i}}\left[\mathrm{IP}\right.\right.$ Mary thinks [VP $t_{i}$ is the smartest]]]]]

b. ${ }^{*}\left[\mathrm{NP}\left[\mathrm{NP}\right.\right.$ the boy [CP $_{\mathrm{C}}$ who $_{\mathrm{i}}\left[\mathrm{IP}\right.$ I like the teacher [CP who [IP has taught $\left.\left.\left.\left.\left.t_{i}\right]\right]\right]\right]\right]$

c. *[NP [NP the boy ${ }_{\mathrm{i}}\left[\mathrm{CP} \mathrm{who}_{\mathrm{i}}\right.$ [IP I will be happy [CP if [IP you like $\left.\left.\left.\left.\left.t_{i}\right]\right]\right]\right]\right]$

d. *[NP [NP the boy $\left[\mathrm{CP}_{\mathrm{Cho}}\right.$ [IP I wonder [CP why [IP John has taught $\left.\left.\left.\left.\left.t_{i}\right]\right]\right]\right]\right]$

Segundo Kenedy (2014), o trace “t”, encontrado em (7a) serve como exemplificação e confirmação das características (i) e (ii), apresentadas anteriormente. Por outro lado, os exemplos de (7b) a (7d) são agramaticais, pois ferem o princípio de subjacência, ferindo as relações de longa distância postuladas por Chomsky (1977).

Segundo Medeiros Júnior (2014), a proposta de Chomsky (1977) fundamenta-se sobre o que Chomsky chamou de "gramática nuclear", constituída de

dois grupos de regras básicas: (1) duas regras transformacionais e (2) três regras interpretadas, tais como dispostas a seguir:

1. a) mover NP

b) mover WH

2. a) Regra recíproca: atribuir a cada uma das partes o traço [+anafórico a $i$ ] numa estrutura contendo NP;

b) Anáfora ligada: atribuir a um pronome o traço [+anafórico a $i]$ numa estrutura contendo NP, no contexto [NP - Possessivo - Nx].

c) Referência disjuntiva: atribuir a um pronome o traço [- anafórico a $i$ ] numa

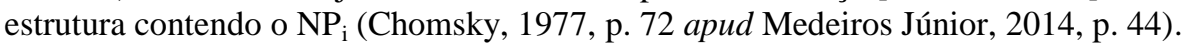

Essa proposição postulada por Chomsky, segundo Kenedy (2014), resolvia a maior parte dos problemas que havia, no momento, acerca das construções relativas. Apesar disso, trazia à tona outros dois problemas que precisavam ser resolvidos para que a teoria acerca das relativas fosse mais firme e completa. Tais problemas eram: (i) correferência e o compartilhamento de traços entre o elemento-QU e o nome relativizado; e (ii) a possibilidade, não aplicada ao português, dessas orações serem construídas sem o elemento-QU expresso.

O primeiro problema, que trata da correferência e compartilhamento de informações entre o pronome relativo e o nome que encabeça a relativa, foi resolvido por Chomsky (1977) por meio de uma regra de predicação aplicada em LF. Aqui, segundo Kenedy (2005, 2014), mais uma vez, temos a solução para um problema apresentando outro a ser analisado e resolvido, visto que tal regra solucionava o problema da interpretação da correlação entre o pronome relativo e o nome relativizado, mas não explicava como determinados traços morfossintáticos, tais como os de gênero, poderiam ser compartilhados entre os dois elementos envolvidos na relativização. 
Vale lembrar que o compartilhamento desses traços é uma das características mais interessantes das orações relativas, segundo De Vries (2002), uma vez que são duas orações diferentes e, entre elas, estabelece-se uma relação profunda de compartilhamento de informações sintáticas e semânticas, como discutido no começo deste capítulo. O problema trazido pela criação de uma regra especial de interpretação que seria aplicada somente em LF é apresentado por Kenedy da seguinte forma:

\begin{abstract}
Primeiramente, ela (a regra de predicação) é capaz de associar livremente NP e $w h$, sem precisar enfrentar qualquer tipo de restrição, como, por exemplo, as condições de ilha, já que, aplicada em LF, não está sujeita à subjacência. Esse poder ilimitado de indexação confere à regra de predicação um caráter imotivado incompatível com os rumos e rigores da pesquisa linguística formal contemporânea. Em segundo lugar, a regra de predicação não é capaz de explicar de que maneira NP e wh chegam a compartilhar certos traços morfossintáticos como gênero, número e Caso. Dado que esses traços são estabelecidos/checados numa relação sintática local, parece incongruente que uma regra aplicada em LF possa determinálos (Kenedy, 2002, p. 24, grifos nossos).
\end{abstract}

Além disso, ainda segundo Kenedy (2014), outro problema não teria sido plenamente resolvido pelo modelo tradicional de derivação das relativas. Seria, como apontado anteriormente, a possibilidade que línguas, como o inglês, têm de gerar relativas sem que haja, em sua derivação, a presença de um elemento-wh, como mostrado em (7), a seguir.

$$
\begin{aligned}
& \text { The book [CP [IP I read last } \\
& \text { o livro eu li passada semana } \\
& \text { 'O livro que eu li semana passada'. (Kenedy, 2014, p. 18) }
\end{aligned}
$$

Tal exemplo, de construção impossível no português, causaria a falta de saturação do verbo da oração encaixada, visto que essa não apresentaria nenhum vestígio ou cópia, a partir de uma visão minimalista, em posição de argumento interno, ainda que esse seja necessário pela transitividade do verbo, que pressupõe "alguém que leia e o objeto lido". Falta, no caso, o objeto lido.

A derivação desse tipo de relativa, que ainda representa um desafio para os sintaticistas em geral, tentou ser resolvida, segundo Kenedy (2014), por Chomsky (1995), com a postulação de um Operador Nulo (OP), que desempenharia o papel de pronome relativo, saturando o verbo da relativa. Ainda para Kenedy (2014), o maior problema dessa postulação, no caso, seria sua incongruência com o momento atual da teoria, o Programa 
Minimalista, que busca preservar, na derivação das estruturas, somente aquilo que é natural e não um mero construto teórico.

\subsection{O modelo Raising: em competição com o tradicional}

O modelo Raising de derivação de orações relativas surgiu, ainda na década de 1960, possivelmente com o influente trabalho de Brame (1968), como uma opção para o modelo tradicional proposto por Lees (1960) e aprimorado, anos mais tarde, por Chomsky (1977). Para Brame (1968), a derivação das orações relativas não seria feita a partir de duas orações não relativas que passariam por uma série de transformações até que a relativa, já com o pronome relativo, fosse adjungida à oração matriz. Na visão do autor, apresentada por Kenedy (2014), o nome relativizado nasceria no interior da oração relativa e, de lá, seria alçado para a posição de Spec-CP, adjungindo-se ao que o autor chamou de "art", ou, hoje, ao núcleo do determinante $\mathrm{D}$, permitindo a leitura relativizada.

Segundo afirma Medeiros Júnior (2014), o pensamento de que a relativa é um termo que funciona como complemento de D, em um DP, remonta ao ano de 1964, com o trabalho de Carlota Smith. A autora argumenta que a relação entre a relativa e o determinante, núcleo do DP, é tão profunda que, dependendo do tipo de núcleo selecionado, há a seleção da relativa que poderá, ou não, ser utilizada no processo de derivação.

Para Vergnaud (1974), a postulação de Lees (1960) e Chomsky (1965), em momento anterior ao modelo tradicional desenvolvido em 1977, peca ao afirmar que a derivação das relativas baseava-se nas regras de transformação e consequente apagamento do elemento repetido no interior da cláusula subordinada. Na visão do autor, o que ocorreria, no momento da derivação, seria a chamada promotion analysis, na qual há o alçamento do nome do interior da relativa para uma posição externa ao $\mathrm{CP}$, já no domínio da oração matriz, à qual se liga a relativa.

Segundo Kenedy (2014), esse modelo, ainda no momento transformacional da teoria gerativa, foi aprimorado e discutido, na década de 1970, por Schachter (1973), Vergnaud (1974) e pelo próprio Brame (1976). Na visão desses autores, o nome relativizado, após passar pelo processo de transformação, seria alçado e adjungido ao determinante em um DP/NP que estaria na oração matriz. Nas palavras de Kenedy (2014, p. 22), "a expressão N relativizada é, de fato, um constituinte interno à cláusula relativa, que, de sua posição argumental, é alçado para Spec-CP, no domínio da oração relativa". Segundo o autor, o 
esquema de transformação da relativa, nesse modelo, poderia ser assim resumido (Kenedy, 2014, p. 21):
a) oração não relativa: [o impressionou a todos]
b) oração relativa: [argumento que Paulo apresentou]
c) adjunção: [o [argumento que Paulo apresentou] impressionou a todos]
d) raising do N-alvo: [o argumento $_{\mathrm{i}}$ [ $t_{i}$ que Paulo apresentou] impressionou a todos]

Ainda segundo Kenedy, o modelo Raising seria aprimorado pelo trabalho seminal de Kayne, na década de 1990, quando o autor propõe que não há adjunção da oração relativa ao DP, mas que tais orações seriam complementos do núcleo funcional D, em um DP. Tal forma de pensamento, mais desenvolvida abaixo, dá conta das, já citadas e exemplificadas anteriormente, três generalizações propostas por Chomsky (1977), a saber: (i) há nas relativas uma lacuna; (ii) ocorrem nelas relações estruturais de longa distância - essenciais à ligação entre o nome relativizado e o pronome relativo ; e (iii) há sensibilidade às restrições de ilha.

Seguindo o modelo Raising, percebe-se que o nome relativizado N, presente no DP, é gerado em posição argumental ainda no domínio do $\mathrm{CP}$, e, ao ser movido para a posição de Spec-CP, gera uma lacuna, que consegue estabelecer relações de longa distância com o N movido, na própria oração relativa. A postulação da derivação no modelo Raising pode ser encontrada em (8), em generalização retirada de Kenedy (2014, p. 22), a seguir.

(8) $\left[\mathrm{D}\left[\mathrm{CP} \mathrm{ALVO}_{\mathrm{i}}\left[\mathrm{IP} \ldots t_{i} \ldots\right]\right]\right.$

Em (8), acima, percebe-se que o nome relativizado, chamado por Kenedy de "Alvo", é gerado no domínio de IP, dentro ainda do CP e, em seguida, é movido para a posição de Spec$\mathrm{CP}$, como dito anteriormente.

Além disso, a postulação desse movimento resolvia, imediatamente, dois dos problemas gerados pela postulação do modelo tradicional: o compartilhamento de traços entre o nome relativizado e o pronome relativo, e torna desnecessária a regra de interpretação atribuída a LF. Tais problemas seriam resolvidos pelo fato do nome relativizado encontrar-se, então, no domínio do CP, não mais no do DP. Vale ressaltar que a noção de movimento não é exclusiva do modelo Raising, uma vez que, no modelo On Wh-movement, há também alçamento após as transformações. Aqui, no caso, modifica-se o elemento alçado: passa do pronome relativo para o NP relativizado. 
Para Kayne (1994), a derivação, no modelo aprimorado por ele, seria possível a partir de alguns passos, a saber: (i) o núcleo do DP é gerado externamente, no espaço da relativização, como parte dos requerimentos de c-seleção do verbo da oração encaixada, no caso, a relativa; (ii) o papel-temático é atribuído e há valoração do traço de Caso do DP ocorrendo via concordância com a projeção funcional; e (iii) o movimento envolvido no alçamento do DP para Spec-CP é considerado A', deixando uma cópia que não será foneticamente realizada na posição de base.

Havendo pronome relativo, há a necessidade de mais um movimento, o do núcleo do DP que precisará ocupar a posição de especificador da projeção para completar a derivação. É o que se percebe, a seguir, com a exemplificação retirada de De Vries (2002, p. 112), em que há, inicialmente o movimento-A’ e, depois, para fins de linearização, movimento do núcleo

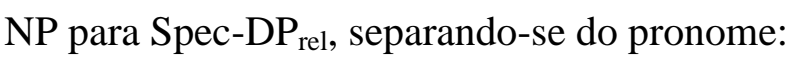
a. [DP [D' The [CP I painted [DP-rel which [NP house]]]]]
b. [DP[D, The [CP [DP-rel which [NP house] $]_{\mathrm{i}}\left[\mathrm{C}\right.$, I painted $\left.\left.\left.\left.t_{i}\right]\right]\right]\right]$
c. [DP[D' The $\left[\mathrm{CP}\left[\mathrm{DP}-\mathrm{rel}[\mathrm{NP} \text { house }]_{\mathrm{k}}\left[\mathrm{D} \text { 'rel which } t_{k}\right]\right]_{\mathrm{i}}\left[\mathrm{C}\right.\right.$, I painted $\left.\left.\left.\left.t_{i}\right]\right]\right]\right]$

Essa descrição de derivação, em (9), seria aplicada às relativas classificadas como restritivas, as quais apresentam uma relação de intersecção entre os conjuntos denotados pela relativa e pelo nome relativizado (essa relação será aprofundada no quarto capítulo desta dissertação). Para o caso das apositivas, em que ocorre a coincidência dos dois conjuntos envolvidos, Kayne (1994) propõe que haverá um movimento adicional, mas já em LF: o IP da relativa é alçado para a posição de Spec-DP, licenciando a interpretação semântica de igualdade com o núcleo nominal, uma vez que passa a ser c-comandado pelo determinante. A derivação, proposta por Kayne (1994) e modificada por Bianchi (2002), é apresentada, a seguir, em (10).

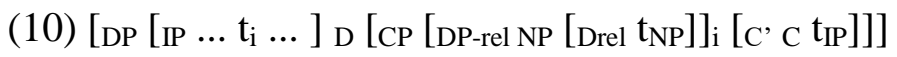

Em (10), segundo Kayne (1994), há movimento de C', indicado ao final da derivação, para a posição de Spec-DP, fato que geraria, segundo o autor, a leitura apositiva, como dito anteriormente. No caso deste trabalho, concentro-me nas relativas restritivas, visto que a leitura de maximalização é, usualmente, feita como uma leitura restritiva. 
Bianchi (1999) postula, a partir da teoria defendida por Kayne (1994), e atendendo à necessidade de explicação dos movimentos no modelo Raising, que o movimento do núcleo nominal para Spec-CP é motivado pela necessidade do determinante externo em checar valorar um traço-N de seleção que só pode valorado em presença de um elemento de categoria nominal que pertença a seu domínio mínimo. O modelo defendido por Bianchi (1999) é apresentado a seguir, em (11).

(11) [DP the [CP [NP picture] [ $\mathrm{C}^{\prime} \mathrm{C}$ [XP [DP which $\left.\mathrm{t}_{\mathrm{NP}}\right]\left[\mathrm{X}^{\prime} \mathrm{x}\right.$ [IP Bill liked $\left.\left.\left.\left.\left.\mathrm{t}_{\mathrm{i}}\right]\right]\right]\right]\right]$

Na representação em (11), é possível perceber outra modificação feita por Bianchi (1999) com relação ao modelo apresentado por Kayne (1994). Tal modificação, considerado por De Vries como um aprimoramento à teoria Raising, parte da postulação da autora acerca de uma camada intermediária, chamada por ela de XP, entre o I e o C, seguindo proposta de Rizzi (1997), a qual o autor nomeou de CP-Split Hypothesis ("Hipótese do CP cindido"). Essa postulação foi utilizada, por Bianchi, como a derivação encontrada nas relativas com elemento-wh, não aplicada às relativas-that.

Para De Vries (2002), os elementos-QU encontrados nas relativas apresentam, à semelhança dos pronomes interrogativos, um traço $[+w h]$ que motivaria, por si só, o movimento desse elemento para Spec-CP. Tal movimento, além de atender a necessidades de checagem desse traço, ocorrem porque os elementos-QU precisam mover-se para a posição mais alta da derivação para que sejam checados outros traços presentes no elemento, tais como o Caso e os traços-phi, que também precisam ser valorados de modo manifesto na sintaxe. Em (12), apresenta-se a derivação proposta por De Vries (2002, p. 123), explicada em detalhes a seguir. A derivação do autor é fundamentada em um exemplo do alemão, traduzido para o inglês (com tradução para o português em seguida):

(12) Ich fürchte den Herrn der eine Pistole trägt.

'I fear the gentleman who carries a gun'

'Eu temo o senhor que carrega uma arma'
(a) [DP-rel der [NP Herrn]]
(b) $\left[\mathrm{DP}-\right.$ rel $[\mathrm{NP} \text { Herrn }]_{\mathrm{h}}$ der $\left.\mathrm{t}_{\mathrm{h}}\right]$
(c) [vP [DP-rel Herrn der $\left._{\mathrm{h}}\right]$ [v, eine Pistole trägt]] 
(d) [IP [DP-rel $\operatorname{Herrn}_{\mathrm{h}}$ der $\left.\mathrm{t}_{\mathrm{h}}\right]_{\mathrm{i}}$ [I, I [vP $\mathrm{t}_{\mathrm{i}}$ eine Pistole trägt]]]

(e) [CP [DP-rel Herrn ${ }_{h}$ der $\left.t_{h}\right]_{i}\left[C^{\prime}{ }^{C}\right.$ [IP $t_{i}$ ' I [vP $t_{i}$ eine Pistole trägt] $\left.]\right]$

(f) [DP den [CP [DP-rel Herrn ${ }_{h}$ der $\left.t_{h}\right]_{i}\left[C^{\prime}{ }^{C}\right.$ [IP $t_{i}{ }^{\prime}{ }_{i}\left[v P t_{i}\right.$ eine Pistole trägt] $\left.]\right]$

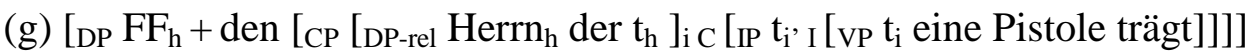

(h) [CP Ich fürtche $\left[{ }_{D P} \mathrm{FF}_{\mathrm{h}}+\right.$ den [CP Herrn $\mathrm{h}$ der eine Pistole trägt]]]

Para De Vries (2002), a derivação inicia-se com a geração, na sentença encaixada, do núcleo nominal, que nasce como complemento do pronome relativo, formando, com esse, um DP-relativo, à maneira proposta no modelo Raising. Como dito anteriormente, o autor defende a necessidade de checagem, ou valoração, de determinados traços, fato que motivaria o movimento para a posição de Spec-DP rel. Essa checagem seria, para o autor, realizada por meio da concordância que ocorre quando o elemento "pousa" nessa posição. Essa é uma relação bastante debatida pelo autor, que vê na necessidade de apresentação das mesmas marcações entre o D e o $\mathrm{N}$ envolvidos no processo uma das características mais interessantes das orações relativas.

Continuando a derivação, De Vries (2002) argumenta que o $\mathrm{DP}_{\text {rel }}$ é selecionado como sujeito do predicado verbal, concatenando-se ao V' para formar o VP após o preenchimento dos requisitos de seleção argumental. O movimento do $\mathrm{DP}_{\text {rel }}$ sujeito para Spec-CP seria, na visão do autor, motivado para a checagem de Caso, sendo esse um movimento-A'. Por fim, após aplicação da operação merge entre o $\mathrm{D}$ externo e o $\mathrm{CP}$ relativo, o novo elemento formado é inserido na oração matriz e tomado, então, como argumento no VP, completando o longo processo de derivação dessas orações, apresentado no início desta explicação, em (12).

Partindo da teoria mais forte acerca do modelo Raising, a postulada por Kayne (2014), Kenedy $(2002,2014)$ defende, a partir da compilação de várias características das orações relativas, que alguns fatores contribuem para a comprovação de que o CP-relativo seria, na verdade, um complemento do núcleo funcional $\mathrm{D}$, como defendido pela maior parte dos autores (Kayne, 1994; Bianchi, 1999; De Vries, 2002; Kenedy, 2002, 2007 e 2014; entre outros) que adotam o modelo Raising em suas análises acerca das orações relativas, em especial das que apresentam a classificação restritiva, centro da maior parte dos estudos sobre tais cláusulas.

Tais fatores são assim divididos por Kenedy (2002, p. 41): “(i) as implicações do LCA; (ii) a correlação entre determinante e relativa; (iii) a ocorrência de possessivos pósnominais relacionados à cláusula relativa; (iv) a distribuição de certas expressões idiomáticas 
quando relativizadas; (v) aspectos da teoria da ligação; (vi) propriedades de escopo do DP alvo;”. Em nossa argumentação, exploraremos somente três dos aspectos apresentados por Kenedy (2002): (i) as implicações do LCA; (ii) a correlação entre determinante e relativa; e (iv) a distribuição de certas expressões idiomáticas quando relativizadas. Isso se dá pela compreensão de que esses aspectos buscam a comprovação da organização [D CP] e atendem à argumentação deste trabalho, visto que fundamentam o pensamento acerca das orações maximalizadoras, desenvolvido à frente.

\subsubsection{O Axioma de Correspondência Linear (LCA)}

A proposta de Kayne (1994) modifica, completamente, como discutido anteriormente, o quadro teórico do modelo Raising, além de apresentar a formalização necessária para que os sintaticistas possam pensar de forma diferente o processo de relativização. Para Kayne (1994), as orações relativas seriam, necessariamente, argumentos de um núcleo funcional $\mathrm{D}$, ocorrendo sempre à direita de tais núcleos, o que seria, na realidade, sua posição de base. Ou seja, para o autor, os movimentos ocorreriam no interior das cláusulas relativas e do DP, sem envolver movimento da própria oração. Para tanto, o autor defende que a relação entre núcleos e argumentos ocorre conforme argumentação a seguir.

Segundo o Programa de Princípios e Parâmetros (P\&P), proposto inicialmente por Chomsky (1981), na Teoria da Regência e Ligação, as línguas naturais se dividiriam em dois tipos: as línguas de ordem Núcleo-Complemento (H-C) e as de ordem Complemento-Núcleo (C-H), com marcação feita pelo input da língua do Parâmetro da Ordem. Assim, línguas como o português seriam linearizadas com os complementos sendo gerados à direita dos núcleos, enquanto línguas como o japonês seriam linearizadas com a geração de complementos à esquerda dos núcleos. A postulação da relação $\mathrm{H}-\mathrm{C}$ ou C-H pode ser aplicada, também, às adjunções, que podem ocorrer, segundo o P\&P, à direita e à esquerda.

Para Kayne (1994), essa seria uma postulação equivocada da teoria, uma vez que a Gramática Universal dos falantes deveria ser extremamente rígida quanto à linearização dos Núcleos e Complementos, com esses últimos sendo gerados, sempre, à direita dos primeiros. Segundo o autor, as línguas que se organizam de outra forma o fazem por uma operação Move que levaria à linearização C-H apresentada em Spell-out. Com isso, Kayne postula que a posição à direita dos núcleos é reservada somente aos complementos, inviabilizando a adjunção nessa posição. Aqui, encontra-se a grande modificação para o pressuposto do 
modelo Raising formalizado por Kayne (1994). Se a posição à direita é reservada à geração de complementos e essa costuma ser a posição de ocorrência das orações relativas, tais cláusulas funcionariam, obrigatoriamente, como complementos do núcleo funcional $\mathrm{D}$, formando o Sintagma [D CP], inviabilizando a ideia de adjunção proposta pelo modelo tradicional Whmovement.

Para formalizar a ideia de seu LCA, Kayne (1994) propõe que o modelo de c-comando simétrico precisaria ser reformulado e trocado por uma proposta que o autor chamou de ccomando assimétrico. Tal revisão do processo de c-comando atenderia à necessidade de organização linear dos enunciados, resultado direto das relações hierárquicas sintáticas. Assim, a noção de um CP funcionando como complemento de um núcleo D, em um DP, atenderia a essas necessidades. Para o autor, segundo seu axioma, a diferença entre as relativas e os demais CPs, principalmente os completivos verbais, seria o núcleo a ser complementado. No caso das relativas, como visto anteriormente, a complementação se daria ao D, em um DP; e, no último caso, os completivos atuariam ligados a um NP, também em posição de complementos.

O c-comando assimétrico, uma das principais contribuições de Kayne (1994), impõe severas restrições sobre as representações sintáticas em geral. Para o autor, "o c-comando assimétrico, invariavelmente, mapeia com precedência linear” (Kayne, 1994, p. 3), levando em consideração, na visão do autor, as necessidades de linearização futuras e as proibições impostas pela faculdade da linguagem.

Na visão de Kayne (1994), tal formato de c-comando, independente dos símbolos terminais que se relacionam em uma estrutura sintática, há, sempre, três propriedades básicas em uma sentença. Nas palavras de Faria (2014, p. 264), “(i) é transitiva (se xLy e yLz, então xLz); (ii) é total (para qualquer x, y distintos, ou xLy ou yLx); e (iii) é assimétrica (não pode xLy e yLx)". Ainda para Faria (2014, p. 265), há "uma correspondência entre a ordem linear de terminais e a relação de locais não terminais por c-comando, mediada pela relação linear total de dominância”. Ou seja, para Kayne (1994), no LCA, a relação de c-comando está ligada aos nós não-terminais, não envolvendo os terminais.

Ao analisarmos o LCA, é interessante trazer à tona algumas implicações que tal axioma, tão radicalmente contrário à teoria então vigente, apresenta. Para Kayne (1994), tais implicações seriam: (i) a ordem "especificador-núcleo-complemento" é a única licenciada pela faculdade da linguagem; (ii) os movimentos para a direita são proibidos, independente de serem de núcleo para núcleo ou de não-núcleo para não-núcleo; (iii) partindo da implicação 
(ii), as adjunções só são, logicamente, liberadas a ocorrer à esquerda do núcleo; (iv) tais adjunções só são permitidas de núcleo a núcleo e de não-núcleo a não-núcleo.

\subsubsection{A forte relação estabelecida entre D e CP}

Outro fator que aparece como forte indício do modelo Raising e sua proposta de que o CP-Relativo é complemento do núcleo $\mathrm{D}$, e não uma adjunção, é a relação bastante forte que se estabelece entre o determinante e a relativa. Tal relação pode ser visualizada com relação à utilização dos artigos definidos em alguns casos específicos e à utilização de determinadas expressões que só podem acontecer com a realização de uma relativa. Os casos tratados a seguir não conseguem ser explicados pelo modelo tradicional e, por isso, fazem com que haja a necessidade de recorrermos ao modelo Raising para explicá-los. Essa é uma das relações mais importantes para o pensamento aqui desenvolvido, de que as relativas de grau apresentam um comportamento diferente das demais relativas, visto que a relação entre tais relativas e seus determinantes é intrínseca e profunda.

Há, em português, como em outras línguas, casos em que o verbo ou o substantivo não podem ser determinados por artigos definidos. É o que acontece com o verbo haver existencial e alguns substantivos próprios. Com relação ao verbo haver existencial, Kenedy (2014, p. 30) aponta, como exemplos, os enunciados abaixo:

(13) a. [DP Os [CP livros $_{\mathrm{i}}$ que havia $t_{i}$ na biblioteca]] eram bons.

b. *[vP havia [DP Os [NP livros bons]] na biblioteca].

Segundo o autor, o exemplo encontrado em (13a) é gramatical, pois o complemento do artigo definido é o CP-Relativo, diferente do que mostra o exemplo (13b), em que o verbo seleciona como complemento um DP que, por sua vez, apresenta um NP como complemento. No caso, percebe-se que a utilização de NPs como complemento de DPs que são selecionados pelo verbo haver existencial é proibida pela gramática da língua, fato que gera a agramaticalidade da segunda construção. Tal agramaticalidade pode ser explicada pela "restrição de definitude em construções existenciais", típica do português.

Essa mesma relação é possível de ser percebida no uso de outros verbos que, no PB, têm apresentado valores existenciais, à semelhança do verbo "haver". É o que podemos perceber, a seguir, em (14), com os verbos "estar" e "ter". 


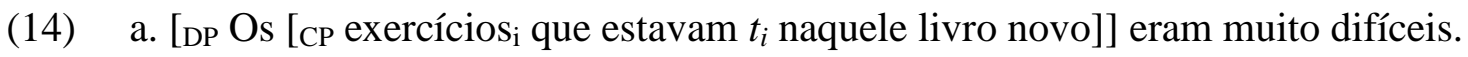

b. *[vp estavam [DP os [NP exercícios difíceis]] naquele livro novo].

c. [DP A [CP água que tinha $t_{i}$ na garrafa]] foi derramada rapidamente.

d. *[vP tinha [DP a [NP água]] na garrafa].

Nos exemplos encontrados em (14), percebe-se, da mesma forma que em (13), que a relação que se estabelece entre a relativa e o núcleo $\mathrm{D}$ é forte a ponto de determinar a gramaticalidade ou a agramaticalidade das sentenças.

Ainda tratando de exemplos encontrados no português, Kenedy (2014), assim como Negrão (2007), percebe que determinados nomes próprios inviabilizam a realização de um artigo que os defina, como é possível observar nos exemplos (15a) e (15b), a seguir, retirados de Kenedy (2014, p. 30).

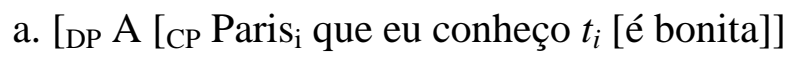
b. *[DP a [NP Paris] é bonita]

Os dois exemplos acima, assim como os exemplos (13) e (14), anteriores, mostram que o N [Paris] não pode ser determinado por um artigo definido, como em (b), diferente do que acontece quando o complemento selecionado é uma relativa. Se o complemento do enunciado (a) fosse o N [Paris], como propõe o modelo tradicional, (b) deveria ser, a exemplo de (a), uma construção gramatical.

Além dos casos de exceção na utilização do artigo, ainda percebe-se a relação intrínseca que determinadas expressões estabelecem com as relativas. Segundo Kuroda (1968, apud Kenedy, 2002), algumas classes de palavras não podem aparecer em construções sem que sejam acompanhadas de um CP-Relativo. Para Schmitt (2000), tais palavras abarcariam as que denotam "expressões tipológicas”, “expressões de medidas”, “expressões resultivas” e “expressões 'com”". Segundo Kenedy (2014, p. 28), essas expressões, a exemplo do que acontece com o inglês, também não podem ser geradas sem uma oração relativa que lhes sirva de complementação, reforçando a ideia de que os CPs-Relativos, diferente do proposto por Chomsky (1977), funcionariam como complemento do núcleo D. É o que se pode perceber nos exemplos abaixo, retirados de Kenedy (2014, p. 28): 
(a) Expressões tipológicas:

*[Eu comprei o tipo de pão] vs [Eu comprei o tipo de pão de que você gosta]

(b) Expressões de medidas:

*[Maria pesa os $45 \mathrm{Kg}$ ] vs [Maria pesa os $45 \mathrm{Kg}$ que Suzana quer pesar]

(c) Expressões resultivas:

*[João pintou a casa com a cor] $v s$ [João pintou a casa com a cor que sua namorada sugeriu]

(d) Expressões “com":

*[Pedro comprou um carro com o motor] $v s$ [Pedro comprou um carro com o motor que ele queria]

Nos exemplos construídos sem a relativa, anteriormente apresentados, quando há contraste com as construções com CP-relativo, percebe-se a impossibilidade de seleção do NP que, no caso dos exemplos gramaticais, só pode estar no domínio do $\mathrm{CP}$, fato que garante sua gramaticalidade. Se os NPs estivessem, nos dois casos, no domínio da oração matriz, deveria haver ou gramaticalidade de todos os exemplos, ou, então, agramaticalidade desses. Apesar disso, não é o que se pode perceber nos exemplos compilados por Kenedy (2014). Assim, é possível reforçar a postulação de Kayne (1994) de que, no caso da relativização, o complemento de D não é o $\mathrm{NP}$, mas o $\mathrm{CP}$, que conterá, em seu domínio, o N-alvo da relativização.

\subsubsection{Uso de expressões idiomáticas}

Uma das estratégias preferidas em sintaxe gerativa, para a comprovação de hipóteses, é a utilização de expressões idiomáticas. A partir da aplicação dos fenômenos às expressões, normalmente é possível testar a adequação de uma proposta. No caso do modelo Raising, os testes com tais expressões constituem evidência a favor da postulação [D CP].

As expressões idiomáticas, segundo Williams (1997 apud Kenedy, 2014, p. 29), "são geradas a partir da articulação entre dois nódulos irmãos, como, por exemplo, aquela presente na relação entre o verbo e o objeto direto". No caso dessas expressões, percebe-se a possibilidade, em muitas línguas, da relativização do objeto direto da expressão, como aponta Kenedy (2014, p. 29), nos exemplos que seguem.

(16) a. O [CP [DP mico $]_{i}$ que [IP eu paguei $\left.\left.t_{i}\right]\right]$ me deixou envergonhado.

b. A [CP [DP mãozinha $]_{i}$ que [iP ele me deu $\left.\left.t_{i}\right]\right]$ resolveu o problema. 
Para o autor, o fato de o nome relativizado ser o objeto direto da expressão serve como reforço de que tal nome relativizado é gerado, na verdade, no domínio do CP-relativo e não no domínio da oração matriz. Nas palavras de Kenedy (2014, p. 29),

\footnotetext{
afinal, considerando as frases citadas para ser uma expressão idiomática, pagar e mico, bem como dar e mãozinha devem ser geradas como nódulos irmãos, isto é, devem estabelecer a relação sintática núcleo+complemento. Ora, como o núcleo (verbal) é indiscutivelmente um constituinte da relativa, seu complemento também deve sê-lo.
}

É interessante notar que, ao aplicar-se o modelo tradicional, Wh-movement, não é possível que o fenômeno da relativização dos objetos das expressões idiomáticas seja explicado. Tal impossibilidade é fruto da incapacidade que a postulação tradicional tem de reconhecer a relação estabelecida, por exemplo, entre o núcleo e seu complemento, na visão de Kenedy (2014), visto que o nome relativizado, "mico", em (16a) e "mãozinha”, em (16b), seriam gerados fora do domínio do $\mathrm{CP}$, já na oração matriz. No caso do modelo Raising, temos o nome relativizado sendo gerado no interior do $\mathrm{CP}$, propiciando a explicação necessária.

\subsection{Conclusões parciais}

Neste capítulo, apresentamos uma pequena revisão bibliográfica acerca da derivação das relativas, à luz da gramática gerativa. Basicamente, percebe-se que a diferença fundamental entre os dois modelos apresentados, Wh-movement, postulado por Chomsky (1977), e Raising, aprimorado por Kayne (1994), Bianchi (1999) e De Vries (2002), está em duas características básicas, a seguir:

(a) a posição de base do nome relativizado; e

(b) o status do CP-relativo.

Para Chomsky (1977), o nome relativizado tem sua posição de base na oração matriz, tendo a relativa como uma adjunção. No caso da proposta Wh-movement, há movimento do elemento-QU, motivado por sua força ilocucional, de sua posição de base, no interior da relativa. O problema de tal postulação, como visto, é que há alguns problemas sintáticos que 
não conseguem ser resolvidos por tal modelo, tais como o compartilhamento de traços entre o elemento-QU e a possibilidade, especialmente em inglês, de construções relativas ocorrerem sem pronomes relativos.

Para Kayne (1994), em seu modelo Raising de relativização, como também para outros autores apresentados, o DP relativizado tem sua posição de base no interior do CP e é alçado (Raising), como o próprio nome do modelo propõe, para a posição de Spec-CP. Na postulação do autor, a oração relativa funcionaria como complemento do núcleo funcional $\mathrm{D}$, em $\left[\mathrm{DP} \mathrm{D}^{0} \mathrm{CP}\right]$.

Como apontado no decorrer do capítulo, a proposta de Kayne (1994) parece-nos a mais completa, visto que uma série de características das relativas só consegue ser explicada por meio desse modelo. Ressalta-se, por fim, que o modelo de Kayne (1994), aprimorado e defendido por Bianchi (1999) e De Vries (2002), é o modelo adotado nesta dissertação, por dar conta da maioria dos aspectos da análise das relativas de grau.

Veremos, no decorrer desta dissertação, que a relação estabelecida entre a relativa de grau e o nome relativizado é extremamente ligada à ocorrência do determinante, fato que parece corroborar para o pensamento de que o CP-relativo funciona, ao menos no caso dessas relativas, como complemento do núcleo D.

Tendo em vista o caráter sintático-semântico de análise proposto no presente trabalho, apresento, no capítulo três, a seguir, a análise das orações relativas de grau, objeto de estudo desta dissertação. Nesse capítulo, analiso as relativas de quantidade e as relativas existenciais que, como dito anteriormente, perfazem, como quero defender, a subclasse das relativas de grau. 


\section{CAPÍTULO 3}

\section{AS RELATIVAS DE GRAU}

\subsection{Introdução}

Neste capítulo, apresentamos uma subdivisão das orações relativas, em relativas existenciais e relativas de quantidade que entendemos comporem uma classe maior, as relativas de grau. Assim, para podermos propor a leitura unificadora dessas duas classificações, analisamos, separadamente, cada uma delas, apresentando suas características particulares e contrastando-as.

Para tanto, apresentamos, em um primeiro momento, as relativas de quantidade, a partir da visão de Móia (2013), McNally (2008) e Grosu \& Landman (1998). Em seguida, apresentamos as relativas existenciais, a partir da visão desenvolvida por Foltran (1988), para as orações existenciais de forma ampla, Móia (2013), McNally (2008), com análise das relativas existenciais, entre outros. Na seção seguinte, apresentamos uma comparação entre as duas relativas, buscando apresentar as diferenças e semelhanças entre as orações, a fim de entendermos a unificação proposta. Por fim, apresentamos a leitura das relativas de grau, entendidas como o conjunto unificado das relativas de quantidade e existenciais.

\subsection{A subdivisão das Orações Relativas}

As orações relativas são, tradicionalmente, divididas em algumas subcategorias determinadas quanto à relação que estabelecem com o nome relativizado, aqui também chamado de cabeça. Entre essas subcategorias, está aquela que é o objeto de estudo desta pesquisa: as relativas de grau, do inglês, Degree Relatives. Nossa proposta, como discutido na introdução deste trabalho, é a leitura unificada de duas subclasses das relativas como relativas de grau, a saber, as relativas de quantidade (RdQ) e as relativas existenciais (REx), bem como a discussão acerca das diferenças e semelhanças de leitura apresentadas por tais relativas.

Essas duas classificações das relativas integram, nesta pesquisa, as relativas de grau, visto que, para nós, ambas apresentam o mesmo comportamento linguístico e classificação semântica, como discutiremos mais profundamente nas próximas seções. As diferenças entre essas duas formas de classificar as relativas é, essencialmente, a leitura que cada uma delas recebe. As RdQ apontam para uma leitura de quantidade, enquanto as REx apresentam uma 
leitura que envolve a substância envolvida, apresentada pelo nome relativizado, além da quantidade, como veremos a seguir.

Percebemos, apesar disso, que há uma leitura unificadora das duas formas de relativas, apresentada pela quantificação máxima do nome relativizado, independente da leitura de substância. Parece-nos que ambas apresentam um DegP, Degree Phrase, ou "sintagma de grau”, postulado como responsável pela leitura quantificadora das relativas, que, por hipótese, se inseriria em diferentes pontos da derivação, com vistas a derivar uma ou outra interpretação; ou, ainda, seria mergido em um mesmo lugar, sem que haja leitura distinta entre as duas, valendo a noção de leitura de grau, apresentada, como dito, pelo DegP.

Como discutiremos a seguir, não há unificação quanto à conceituação desses dois tipos de relativas. Para alguns estudiosos (tais como Grosu \& Landman, 1998; Szczegielniak, 2012), relativas de quantidade e relativas existenciais perfazem um mesmo grupo, com leituras idênticas, enquanto para outros (tais como Móia, 2013; McNally, 2008), seriam duas subclasses de relativas a serem estudadas de forma separada. Sendo assim, nossa proposta é inovadora para o $\mathrm{PB}$, porque busca apresentar a mesma leitura proposta por Grosu \& Landman (1998) para o inglês, a de que as relativas de grau perfazem um grupo com leitura maximalizadora, formadas pelas relativas de quantidade e as relativas existenciais.

Nossa proposta, para o PB, como desenvolvida em seguida, é a de que essas relativas, as de quantidade e as existenciais, devem ser unificadas sob o rótulo de relativas de grau, seguindo Grosu \& Landman (1998) e Szczegielniak (2012), visto apresentarem, como dito anteriormente, uma leitura quantificadora máxima. A seguir, apresentam-se as características de cada uma dessas subclasses das relativas para, em seguida, analisá-las conjuntamente, atentando para as semelhanças e diferenças entre as duas leituras.

\subsubsection{As relativas de quantidade}

As relativas de quantidade, do inglês Amount Relatives, foram estudadas, primeiramente, por Carlson (1977) e discutidas de forma mais profunda quanto ao seu comportamento semântico por Heim (1987). A literatura para tais orações, em inglês, é vasta e, como dito, há, para elas, duas formas de conceituação.

Para parte dos estudiosos, como Móia (2013) e McNally (2008), essas relativas têm, em sua predicação, um valor de quantidade com relação ao nome relativizado, ou seja, a relativa apresenta uma noção quantitativa - máxima a nosso ver - desse nome, como é 
possível perceber a partir dos exemplos a seguir, retirados de Móia (2013) ${ }^{7}$. Vale salientar, para melhor entendimento e comparação dos dados e das postulações apresentados por Móia (2013), que o autor apresenta sua análise a partir do português europeu - PE. Destaca-se, antes da análise dos exemplos apresentados a seguir, que não levamos em conta, neste momento, a possibilidade de dupla leitura que o enunciado (1) apresenta ${ }^{8}$.

(1) Perdemos a batalha porque não tínhamos, nem de perto nem de longe, os soldados que o inimigo tinha.

(2) Seriam precisos vários dias para beber o champanhe que eles derramaram naquela noite.

Como se observa nos exemplos (1) e (2), a oração relativa apresenta uma leitura de quantidade com relação ao nome relativizado. Assim, em (1), o nome "soldados" está sendo quantificado pela relativa [que o inimigo tinha], apontando, como afirma Móia (2013), para a quantidade de soldados que o inimigo tinha. Em (2), o nome "champanhe" também está sendo quantificado pela relativa [que eles derramaram naquela noite]. Nos dois exemplos, percebese que há uma leitura de gradação máxima - apresentação de uma leitura de totalidade - do nome relativizado. Essa leitura, bem como as demais leituras semânticas, será tratada a fundo no capítulo quatro.

Para outra parcela dos que estudam esse fenômeno, as relativas de quantidade apresentam uma dupla identificação em sua leitura: a quantidade envolvida e a substância do nome relativizado. Ou seja, para esses autores, como Grosu \& Landman (1998), a leitura, em (1) e (2), envolve, também, a natureza do nome relativizado, característica essencial à leitura de gradação que os autores propõem. Importaria, então, para os autores, a natureza do nome relativizado, não somente sua quantidade.

Apesar disso, para Móia (2013, p. 473), “a predicação relevante nestas frases não envolve os indivíduos ou as substâncias específicas mencionadas, mas, antes, as quantidades dessas entidades”. O autor utiliza, visando à comprovação de sua hipótese, um teste que prevê

\footnotetext{
${ }^{7}$ Exemplos em Móia (2013, apud McNally, 2008) e adaptados para o português pelo próprio autor.

${ }^{8}$ A leitura de (1), além da noção de quantificação, pode ser entendida como uma leitura de qualidade dos soldados envolvidos no enunciado. Ou seja, é possível entendermos que "perdemos a batalha porque não tínhamos, nem de perto nem de longe, aqueles soldados que o inimigo tinha". Tal leitura não inviabiliza a análise da oração como RdQ, foco de nosso estudo neste momento.
} 
a inserção, antes do nome relativizado, da expressão "o número de", em (1), e "a quantidade de”, em (2), como é possível ver em (1') e (2’):

(1') Perdemos a batalha porque não tínhamos, nem de perto nem de longe, o número de soldados que o inimigo tinha.

(2') Seriam precisos vários dias para beber a quantidade de champanhe que eles derramaram naquela noite.

Vale salientar que, apesar de percebermos que, nos exemplos (1) e (2), temos uma leitura de totalidade do nome relativizado, é inegável a leitura quantificadora, defendida por Móia (2013). Assim, percebe-se, em (1), que a relativa aplica-se ao total de soldados que o inimigo tinha, assim apresentando a leitura máxima, que entendemos acontecer nas relativas de quantidade e nas existenciais. A mesma leitura pode ser aplicada ao exemplo (2), visto que é possível compreender que a relativa apresenta, mais uma vez, a leitura de quantidade total, máxima, com relação ao nome champanhe, relativizado. Encontramos, então, uma leitura de maximalização, que será explorada mais à frente.

Ainda sobre a conceituação das RdQ, McNally (2008) apresenta a ideia de que, nessas orações relativas, há uma leitura completa da quantidade envolvida no processo de relativização do nome-cabeça, como pensamos realmente acontecer. É o que aparece, segundo a autora, no exemplo (3), a seguir.

$$
\begin{aligned}
& \text { Marv put everything he could in his pocket. } \\
& \text { Marv colocou tudo ele pôde em seu bolso. } \\
& \text { 'Marv colocou tudo que pôde em seu bolso'. }
\end{aligned}
$$

A leitura de quantidade, para a autora, independente da substância envolvida no nome relativizado "tudo", ocorre porque Marv colocou em seu bolso todas as coisas que ali - em seu bolso - cabiam, sem que se leve em conta a natureza dessas coisas. Nesse caso, é possível perceber que a entidade envolvida no nome relativizado não está declarada, formando uma relativa que apresenta características exclusivamente quantitativas em sua relação com o nome relativizado. Ainda segundo McNally, essa possibilidade estaria fundamentada nas diferenças que esse tipo de oração apresenta com relação às relativas existenciais, essas, sim, com leitura de substância e quantidade, como veremos mais à frente.

\footnotetext{
${ }^{9}$ Exemplo retirado de Carlson (1977, p. 528).
} 
Apesar de (3) apresentar, conforme McNally, somente uma leitura de quantificação, mais uma vez é possível que percebamos que a leitura explorada é a de maximalização, uma vez que Marv colocou em seu bolso todas as coisas que pôde colocar, com noção de gradação máxima dessas coisas. Mais uma vez, ressalto que a leitura de gradação máxima, essencial às relativas de grau, pode ser vista nas RdQ.

Nessa esteira, segundo Carlson (1977), as relativas de quantidade apresentam duas características sintáticas próprias que não são compartilhadas pelas outras subcategorias das relativas, a saber: (a) a utilização exclusiva de determinantes definidos/universais em suas construções com o nome relativizado, como nos mostram os exemplos (4) e (5), retirados de McNally (2008); e (b) o fato de algumas relativas de quantidade não aceitarem ser realizadas, em algumas variantes do inglês, com os relativos which e who, por exemplo, sempre preferindo a realização com that. Essa particularidade será aproveitada por Grosu \& Landman (1998) na construção de sua argumentação com relação à leitura de grau unificada, uma vez que as Degree também rejeitam construção com os dois pronomes: which e who.

Essa segunda característica não pode ser facilmente encontrada em português, uma vez que, em nossa língua, o relativo que, concorrendo com o qual e suas variantes, pode ocorrer em praticamente todas as relativizações. No caso do relativo quem, em PB, esse é utilizado de forma específica, ligando-se somente a nomes que apresentem traço [+humano] e acompanhado de preposição. Há alguns casos, pouco comuns no português, do uso do pronome "quanto" como elemento-QU de introdução de algumas relativas. Tais casos serão analisados na continuação da pesquisa ${ }^{10}$.

(4) Max put many things that he could in his pocket. Max colocou muitas coisas que ele pôde em seu bolso. 'Max colocou as coisas que pôde em seu bolso.'

(5) It would take days to drink some champagne they spilled that evening. EXP iria levar dias beber algum champanhe eles derramaram aquela noite. 'Levaríamos dias para beber um pouco do/todo/o champanhe que eles desperdiçaram naquela noite.'

\footnotetext{
${ }^{10}$ Não vamos nos ater ao caso das ocorrências do pronome "quanto", como em "Ele pôs tudo quanto pôde no bolso" ou "Fez tudo quanto pôde para se salvar", deixando a análise desses casos para a continuação da pesquisa, em nível posterior de pós-graduação.
} 
No exemplo (4), percebe-se que não seria possível a realização sem o determinante, como demonstrado em (6), o mesmo acontecendo com o exemplo (5) que, sem o acréscimo do determinante, mostra-se agramatical, como demonstrado em (7):

(6) *Max coloca coisas que consegue em seu bolso.

(7) *Levaríamos dias para beber champanhe que eles desperdiçaram naquela noite.

Móia (2013) ainda aponta algumas características sintático-semânticas desse subtipo de relativas. A primeira delas dá conta da importância da informação veiculada pelo nomecabeça na construção. Segundo o autor, essa informação seria importante em três diferentes posições estruturais: (i) no interior da relativa, de onde teria sido deslocado para a posição de Spec-CP, como propõe Kayne (1994); (ii) na sentença matriz, funcionando como quantificador, por identificarem, ainda que de forma indireta, um valor numérico; e (iii) novamente na sentença matriz como núcleo do DP relativizado.

Móia (2013) também elenca mais uma característica de origem semântica para as RdQ: o fato de ser proibitiva a sua construção com nomes relativizados que não sejam acompanhados de determinantes definidos. Segundo o autor, essa é uma característica comum às construções de quantidade no inglês e no português. Para Móia (2013, p. 478), "esse SN (o nome relativizado) é incompatível com, por exemplo, quantificadores existenciais, cardinais ou fracionários". Tal incompatibilidade, para Grosu \& Landman (1998), é fruto da leitura maximalizadora desse tipo de relativa, típica das relativas grau, que será aprofundada mais à frente neste trabalho. Vale ressaltar, aqui, que essa é uma característica que as RdQ compartilham com as REx, que também não podem acontecer sem que o nome relativizado seja definido.

Além disso, Móia (2013) apresenta duas características pouco exploradas das RdQ em português. A primeira delas, segundo ele, dá conta do fato das RdQ "aparecem associadas às três modalidades de quantificação identificadas em Peres (1992, apud Móia, p. 481): contagem, medição e graduação" (Móia, 2013, p. 481).

Nas relações com leitura de contagem, para o autor, há a possibilidade de paráfrase com a inserção de "a quantidade de/o número de", como apresentado no início desta seção. Além disso, o autor indica que os nomes relativizados são plurais contáveis. A segunda leitura, a de medição, é assim descrita por Móia (2013): "Na medição, há estruturas 
parafraseáveis por 'o volume de, a dimensão (ou a quantidade) de $\mathrm{N}$ que' e os nomes são tipicamente singulares não contáveis, embora possam ser excepcionalmente plurais”. Por fim, a leitura de gradação, usualmente associada a nomes abstratos e que trazem informação escalar, pode apresentar paráfrase com a inserção de "o grau de N que", possibilitando a leitura quantitativa nesses casos. Nos exemplos (8), (9) e (10), a seguir, retirados de Móia (2013, p. 481), é possível visualizar as propostas de leitura, respectivamente, de contagem, medição e gradação.

(8) "Um navio, um cais e uma instalação desse tipo junto da Expo 98, com os visitantes que ela atrairá, não são aceitáveis por razões de segurança (...)." (Parafraseável por "com o número de visitantes que ela atrairá").

(9) "Percebido este tributo geral, (...) cada um despenderá a água que quiser." (Parafraseável por "a quantidade de água que quiser").

(10) “[O Partido Comunista] Viverá ou morrerá em função do apoio que tiver.” (Parafraseável por "o grau de apoio que tiver").

A segunda característica apresentada por Móia (2013), como novidade na análise dessas relativas, é uma característica léxico-sintática, relacionada à possibilidade de derivação das RdQ modificando nomes que apresentem hiperônimo de quantidade, como nos casos em que há realização de expressões como "a quantidade de, o número de", entre outras; e a possibilidade de derivação das orações com essa informação implícita.

$\mathrm{O}$ autor aponta uma possibilidade interessante para essa dupla possibilidade de realização. Primeiro, mostra que ambas estão em forte competição no PE e que a utilização do hiperônimo, muitas vezes será opção para evitar a ambiguidade de leitura entre uma referencial e uma RdQ, como acontece nos exemplos que seguem, retirados também de Móia (2013).

(11) As plantas morrem sempre em casa de Ana, ponha ela a água que puser.

(11') As plantas morrem sempre em casa de Ana, ponha ela o tipo de água que puser.

(11”) As plantas morrem sempre em casa de Ana, ponha ela a quantidade de água que puser.

Segundo o autor, o exemplo (11) é ambíguo, visto que pode ser entendido como RdQ, como percebido em (11"), no qual a leitura seria de "a quantidade de água" (com o hiperônimo), possibilitando uma leitura exclusiva de quantidade; e com a leitura apresentada em (11'), em que a leitura de “o tipo de água”, será referencial. 
Além disso, Móia (2013) ainda aponta que as relativas de quantidade, alvo de seu estudo, apresentam, muitas vezes, ambiguidade entre a leitura de quantificação (grau) e a leitura referencial (restritiva) das relativas. Aqui, o autor corrobora o pensamento de que a leitura semântica desse tipo de relativas, as de grau, deve ser diferenciada, como exploraremos mais à frente, da leitura tradicional de restrição. Para demonstrar a referida ambiguidade, o autor utiliza dois exemplos ${ }^{11}$ que serão aqui reproduzidos:

(12) A vitória depende em grande parte dos jogadores que ficarem em campo.

(13) As plantas morrem sempre na casa da Ana, ponha ela a água que puser.

Nos dois exemplos, (12) e (13), anteriores, é possível que a leitura seja feita em termos de quantidade ou em termos de referencialidade. No primeiro caso, haveria possibilidade de classificação típica de uma relativa de grau, a ser posteriormente discutida; ou, no segundo caso, numa leitura restritiva tradicional. As paráfrases possíveis, segundo o autor seriam:

(12') A vitória depende em grande parte de quantos jogadores ficarem em campo.

(12") A vitória depende em grande parte de quais jogadores ficarem em campo.

(13') As plantas morrem sempre na casa de Ana, ponha ela a quantidade de água que puser.

(13”) As plantas morrem sempre na casa de Ana, ponha ela o tipo de água que puser.

O autor ainda destaca que somente as orações que apresentam leitura de quantidade aceitam a inserção de expressões quantificadoras antes do nome relativizado, a exemplo dos testes propostos por ele.

De forma geral, percebe-se que as orações relativas de quantidade apresentam leitura de quantificação do nome relativizado, como o próprio nome já propõe. Entendemos, partindo dessa noção, que tais relativas apresentam não uma leitura quantitativa pura e simples, mas uma operação de gradação máxima do nome relativizado. Para entendermos a noção de totalidade, propomos a inserção do quantificador universal "todo" logo antes do nome

\footnotetext{
${ }^{11}$ Exemplos retirados de Móia (2013, p. 475).
} 
relativizado, nas relativas de quantidade, como se percebe a seguir, em (14), com exemplo retomado de (1).

(14) Perdemos a batalha porque não tínhamos, nem de perto nem de longe, todos os soldados que o inimigo tinha.

Essa característica de gradação máxima, perceptível nas RdQ, também será encontrada nas relativas existenciais, exploradas na seção a seguir, as quais queremos encaixar como relativas de grau, em companhia das RdQ.

\subsubsection{As relativas existenciais $(\mathrm{REx})$}

As relativas existenciais perfazem um grupo de orações relativas que apresentam relação existencial com relação ao nome relativizado. Tais orações apresentam extremo valor para o problema tratado nesta pesquisa, uma vez que, junto com as RdQ, apresentadas na seção anterior, compõem o grupo das relativas de grau, explicadas ainda neste capítulo, com leitura de totalidade, chamada "maximalizadora" pela literatura linguística.

Antes de apresentar a noção de relativas existenciais, é interessante olharmos para as sentenças existenciais de forma geral, principalmente, por, no PB, termos vários verbos que, de forma sincrônica, funcionam, no interior das sentenças, como os chamados verbos existenciais. Como verbos existenciais, entendemos aqueles verbos que, ao serem utilizados em determinados contextos, apresentam significação existencial, tal como podemos perceber a seguir, nas orações relativas apresentadas em (15), (16) e (17).

(15) Os livros [que havia naquela loja] foram vendidos hoje.

(16) Os cachorros [que estavam no canil] latiram durante toda a noite.

(17) Enxotaram as vacas [que tinha no pasto].

Nos exemplos acima, percebe-se que os verbos das orações encaixadas indicam a existência dos nomes relativizados. Em (15), a relativa, entendida como existencial, pode ser assim interpretada por apresentar a existência do nome [livros], relativizado. Ressalta-se que, em (15), o verbo existencial utilizado é o prototípico "haver existencial". 
Em (16), percebe-se a mesma relação de existência, mas com o verbo "estar", que, segundo a literatura, como Foltran (1998) e Avelar (2006), apresenta, em determinados contextos, valor existencial, como discutiremos adiante neste capítulo. Em (17), por sua vez, temos uma construção existencial com o verbo "ter", que concorre, hoje, com o verbo "haver" em alguns de seus sentidos, como o existencial e o temporal.

Inicialmente, é interessante notar que a visão de verbos e sentenças existenciais nunca chamou, como afirma Foltran (1988), a atenção dos gramáticos normativos, a não ser nos casos relacionados à concordância. Para a autora, "estas sentenças teriam como finalidade asseverar a existência de uma entidade. Esta entidade aparece sob a forma de um SN (um DP, em análises mais recentes) que segue o verbo" (Foltran, 1988, p. 4).

Para McNally (no prelo, p. 2), o termo "sentença existencial" dá conta de orações de difícil classificação e serve para designar cláusulas não canônicas "quer por alguns aspectos de sua sintaxe, quer pela presença de um produto lexical distinto”. A autora (no prelo, p. 2) afirma que "essa estrutura não canônica é invariavelmente acompanhada pelo que parece ser uma semântica especial ou uma função do discurso que introduz a presença ou a existência de algum indivíduo", em consonância com a afirmação feita por Foltran (1988).

Dessa forma, percebe-se que a utilização do termo "sentença existencial" é ampla e serve para designar algumas análises que envolvem elementos pouco esperados, tais como os elementos locativos que, muitas vezes, tomam o lugar do sujeito; bem como o funcionamento de alguns verbos, antes impessoais, com preenchimento de sujeito. Nessa esteira, a autora afirma que há uma grande dificuldade, ainda a ser sanada por pesquisas futuras, de encontrarem-se características que expliquem as semelhanças dessas orações translinguisticamente.

Apesar disso, McNally (no prelo, p. 3), argumenta que as línguas tendem a usar elementos construtivos de existência similares para as
sentenças existenciais: verbos de cópula, expressões possessivas ou locativas,
expressões expletivas, como o there do inglês, e predicados especiais que podem ser
relacionados etimologicamente a locativos ou expressões possessivas.

Essa visão, claro, abarca as relativas, apesar dessas não necessariamente aparecerem com um DP que segue o verbo, visto que, na maior parte das vezes em que há relativas existenciais, o DP que "segue o verbo", nas palavras da autora, aparece linearizado à frente do verbo, atendendo à necessidade de movimento do elemento-QU, o qual funciona como relativizador no interior das relativas. É interessante notar que o DP que funcionará como 
complemento do verbo existencial aparecerá, na maior parte das vezes, relativizado como nome cabeça dessas relativas. É o que percebemos no exemplo (18), a seguir.

(18) O cachorro comeu toda a ração que havia na tigela.

No caso do exemplo (18), escolheu-se a construção clássica com o verbo haver existencial, visto que ainda não discutimos a relação verbal existencial do $\mathrm{PB}$, mas esta poderia ter sido construída, por exemplo, com o verbo "estar" ou "ter", sem que houvesse diferença de leitura, ou de construção. No exemplo (18), então, é possível perceber que a relativa [que havia na tigela] é construída com um locativo, visto por Foltran como essencial à significação existencial pretendida. Com relação ao NP/DP que estaria posposto ao verbo, percebe-se que a leitura da oração leva em conta que a interpretação do sintagma [a ração] se dá em posição pós-verbal, visto ser ali sua posição de base.

Entretanto, é interessante percebermos que a posição do pronome relativo está coindexada à posição de base onde é interpretado o DP que se moveu para Spec-CP. Foltran (1988) afirma, ainda, que as sentenças existenciais, de forma geral, precisam ser, na maior parte das vezes, complementadas por um elemento locativo, sendo uma característica encontrada, também, nas relativas existenciais.

As relativas existenciais são, para Móia (2013) e Grosu \& Landman (1998), as que estabelecem uma relação de gradação máxima com o nome relativizado, identificando a entidade envolvida, bem como sua quantidade. A noção seria diferente da RdQ por conta da identificação da entidade envolvida, uma vez que, mesmo nas orações que se apresentam como relativas de quantidade, há leitura de maximalização, visto envolver a totalidade do nome relativizado.

De forma geral, para o inglês, a identificação das REx é feita a partir da inserção do there be, entendido como existencial, segundo Foltran (1988). Essa visão é compartilhada por Heim (1987) e por G\&L (1998), como podemos perceber no exemplo a seguir.

(19) I took with me the three books that therewere on the table.

Eu trouxe comigo os três livros que havia sobre a mesa.

'Eu trouxe comigo os três livros que havia sobre a mesa'. (G\&L, 1998, p. 128)

O exemplo anterior perfaz uma típica relativa existencial em inglês, que ocorre pelo processo chamado there-insertion. Com relação às relativas existenciais em português, 
principalmente no $\mathrm{PB}$, variante usada nesta pesquisa, há diferenças significativas com relação aos verbos, visto que o verbo haver existencial vem sendo menos utilizado pelos brasileiros, especialmente na modalidade oral do Brasil.

Dessa forma, vale analisar, ainda que superficialmente, visto que esse não é meu objetivo neste estudo, os verbos que funcionam, no PB, como verbos existenciais. Os principais verbos são, inegavelmente, o verbo haver e o verbo ter. Segundo Foltran (1988, p. 14),

\begin{abstract}
Detendo-nos um pouco na nossa realidade linguística, constatamos que o verbo ter é largamente empregado na construção impessoal na linguagem falada, principalmente. A literatura moderna, com o intento de valorizar o coloquial, também a utilizou de forma irrestrita. Encontramos esta construção até no pronunciamento de falantes mais cultos. O verbo haver foi deixado para momentos de maior formalidade e percebe-se, inclusive, a necessidade de um certo policiamento por parte do usuário da língua na utilização deste.
\end{abstract}

A autora ainda argumenta que a noção normativa de não aceitação do uso do verbo “ter" em sentido existencial é incapaz de evitar o uso do referido verbo. Nessa mesma direção caminham Callou \& Avelar (2000), ao perceberem que, no PB, há uma enorme concorrência entre o verbo haver e o ter, ambos existenciais. Os autores afirmam, ainda, que o uso desses verbos serve, muitas vezes, para distinguir a existência de uma norma portuguesa, aplicada ao português europeu - PE - e o PB.

Foltran (1988), no que diz respeito aos verbos existenciais, apresenta uma opção bastante interessante de estabelecer uma estrutura que resolva a análise das existenciais. Nas palavras da autora (1988, p. 13), "nossa intenção é dirigir este trabalho no sentido de que se estabeleça uma estrutura existencial e não verbos existenciais. [...] Há outros (verbos, no caso), no entanto, que se encaixam na estrutura estabelecida e podem, assim, ser tratados como existenciais”. Assim, a partir da possibilidade ampliadora que a noção de estruturas existenciais traz, adotamos aqui essa ideia, visto que, nas relativas existenciais, há concorrência entre verbos que apresentam semântica de existência e, também, como defendido neste trabalho, leitura maximalizadora. Consideramos, então, construções existenciais como as que apresentam valor de existência do nome relativizado. 
Para fundamentar a ideia de que as estruturas existenciais podem constituir-se de diferentes verbos, muito além dos canônicos e dos atualmente analisados, a autora propõe a análise dos seguintes exemplos:

(20) Aqui dá muitas frutas.

(21) Só dá este nome na pesquisa. (Foltran, 1988, p. 13)

No caso dos exemplos transcritos em (20) e (21), é possível percebermos que o verbo dar, apesar de não considerado canonicamente como um verbo existencial, apresenta essa leitura, visto que, em (20), podemos compreender que "há muitas frutas aqui", enquanto em (21), entende-se que um determinado nome aparece diversas vezes na pesquisa, ou seja, "só há este nome na pesquisa". Dessa forma, percebe-se que a análise das orações existenciais em português, especialmente no brasileiro, aponta diferenças quanto às leituras feitas para o inglês.

Objetiva-se, ao apresentar essa variação na leitura existencial dos verbos em PB, indicar a riqueza desse tipo de construção em nossa língua, utilizadas de forma constante e extremamente produtiva. Por fim, é interessante que notemos que o verbo estar também pode ser utilizado como verbo existencial, em construções como (22).

(22) O menino comprou as flores que estavam na bancada.

No exemplo (22), percebe-se que o verbo “estar” apresenta significação existencial, fato comum no PB. De forma geral, essa leitura é permitida, também, pela relação que se estabelece entre a oração relativa e o nome relativizado. Isto é, se a oração "As flores estavam na bancada" fosse realizada sem relação de relativa com um nome anterior, não haveria a leitura existencial, fato interessante que pode ser explorado posteriormente. Além disso, a leitura existencial pode ser percebida se houver a troca do verbo "estar" pelo verbo "haver", prototipicamente existencial.

Por fim, vale retomar a importância do estudo das relativas existenciais para nosso problema de trabalho. Avaliamos que tais relativas, em conjunto com as de quantidade, estabelecem uma relação de gradação máxima com relação ao nome relativizado, apresentando uma leitura de grau máximo. 
Assim como demonstrado no final da seção anterior, nas relativas existenciais também há a possibilidade de usarmos o quantificador "todos", seguindo teste proposto por Móia (2013), que propõe a inserção, na paráfrase da relativa de quantidade, do hiperônimo "a quantidade de" antes do nome cabeça.

Nossa proposta é a inserção, diante de relativas de quantidade e de relativas existenciais, na paráfrase, do quantificador universal "todos", demonstrando que não há diferença de leitura com o quantificador ou não. O "todos", então, indica que a totalidade de tal nome é o que está em jogo na leitura do enunciado. É possível percebermos isso em (23).

(23) O menino comprou todas as flores que estavam na bancada.

No exemplo (23), percebe-se que a inserção do quantificador "todas" permite a mesma interpretação do exemplo não parafraseado, em (22). Isso mostra que a leitura permitida pela relativa é de maximalização, apontando que a totalidade do nome relativizado é que está envolvida na leitura do enunciado.

\subsubsection{Contraste entre as RdQ e as REx}

Para Móia (2013), a principal diferença entre as RdQ e as REx é o fato das primeiras permitirem uma leitura exclusiva das quantidades envolvidas na relação com o nome cabeça, enquanto as segundas identificariam, como vimos, as entidades envolvidas, além da quantidade. Seguindo Grosu \& Landman (1998), percebemos que essa ideia pode ser contestada quando se faz a análise do exemplo (24), retomado do exemplo (2), e modifica-se a relação das entidades, como em (24):

(24) *Seriam precisos vários dias para beber o champanhe que eles derramaram cerveja naquela noite.

Para Móia, como apresentado no início dessa seção, o exemplo (23), em sua versão original, apresentaria uma leitura exclusivamente quantitativa, sendo uma RdQ e não uma REx. A agramaticalidade de (24) advém, segundo Grosu \& Landman (1998), da impossibilidade de acrescer-se outra entidade na oração encaixada, fato que permite a 
compreensão de que as relativas de quantidade precisam, também, da identificação da entidade envolvida na relativização.

Percebe-se, então, que o consenso acerca da separação entre relativas existenciais e de quantidade não existe e não nos parece importante, visto que há outras duas características importantes compartilhadas entre essas duas relativas, levando-nos à proposta de tratá-las como relativas de grau. As características que aproximam as duas formas de relativa são, a saber, (i) a impossibilidade de leitura de gradação para as REx e RdQ sem determinante; e (ii) a leitura de maximalização, já indicada anteriormente, que apresenta uma noção de grau completo do nome relativo.

Dessa forma, entendemos que a leitura de quantificação, garantida, como dito acima, pelo uso do determinante diante do nome relativizado, permite a colocação das duas relativas discutidas anteriormente - as existenciais e as de quantidade - em um mesmo subgrupo, o das relativas de grau. A gradação quantitativa dos nomes-cabeça aproxima as duas formas de construção relativa e mostra, como defendido em Kayne (1994), a relação profunda entre o determinante, núcleo do DP, e a relativa, que parece-nos, ainda mais, funcionar como complemento de tal núcleo.

Assim, é possível que entendamos que a separação das relativas de grau entre relativas de quantidade e relativas existenciais acarreta mais problemas do que os soluciona. Partindo disso, nossa hipótese é a de que ambas devem ser tratadas como relativas de grau com uma leitura de maximalização, fato que será explorado no próximo capítulo. Essa relação de maximalização é compreendida a partir da leitura de quantidade máxima apresentada pela relativa com relação ao nome relativizado. Seria, portanto, uma leitura de quantificação universal máxima.

Vale ressaltar, retomando a introdução deste trabalho, que, a nosso ver, a leitura semântica apresentada pelas relativas de grau é, sempre, a de maximalização, em que encontramos a compreensão da totalidade do nome envolvido no processo de relativização.

\subsection{As Orações Relativas de Grau}

As orações relativas de grau formam um grupo de relativas que apresentam leitura de quantificação com relação ao nome relativizado, apresentando, em suas ocorrências, a leitura de uma quantificação máxima desse nome. Tais relativas apresentam, a nosso ver, uma leitura 
de maximalização, que será explorada no próximo capítulo, entendida como uma relação de quantificação máxima do nome envolvido no processo de relativização.

Nesta pesquisa, seguindo Grosu \& Landman (1998), Grosu (2002) e Szczegielniak (2012), aceitamos a hipótese de que as relativas de grau apresentam um "sintagma de grau" DegP - em sua construção, postulação teórica que dá conta da leitura quantificadora apresentada pela relativa.

Tal sintagma seria gerado no interior da relativa e, como postulam G\&L (1998), Grosu (2002) e Szczegielniak (2012), movido para a posição de Spec-CP, ainda que sem realização fonética. Essa visão é essencial para que entendamos, mais adiante, a relação de maximalização que será garantida pelo movimento e interpretação desse DegP.

Para Grosu e Landman (1998), a derivação das orações relativas de grau ocorre como apresentado em (24), a seguir, retirado de Grosu e Landman (1998, p. 131).

(25) Derivação proposta por Grosu \& Landman (1998), para o enunciado “(...) the three books there were on the table"

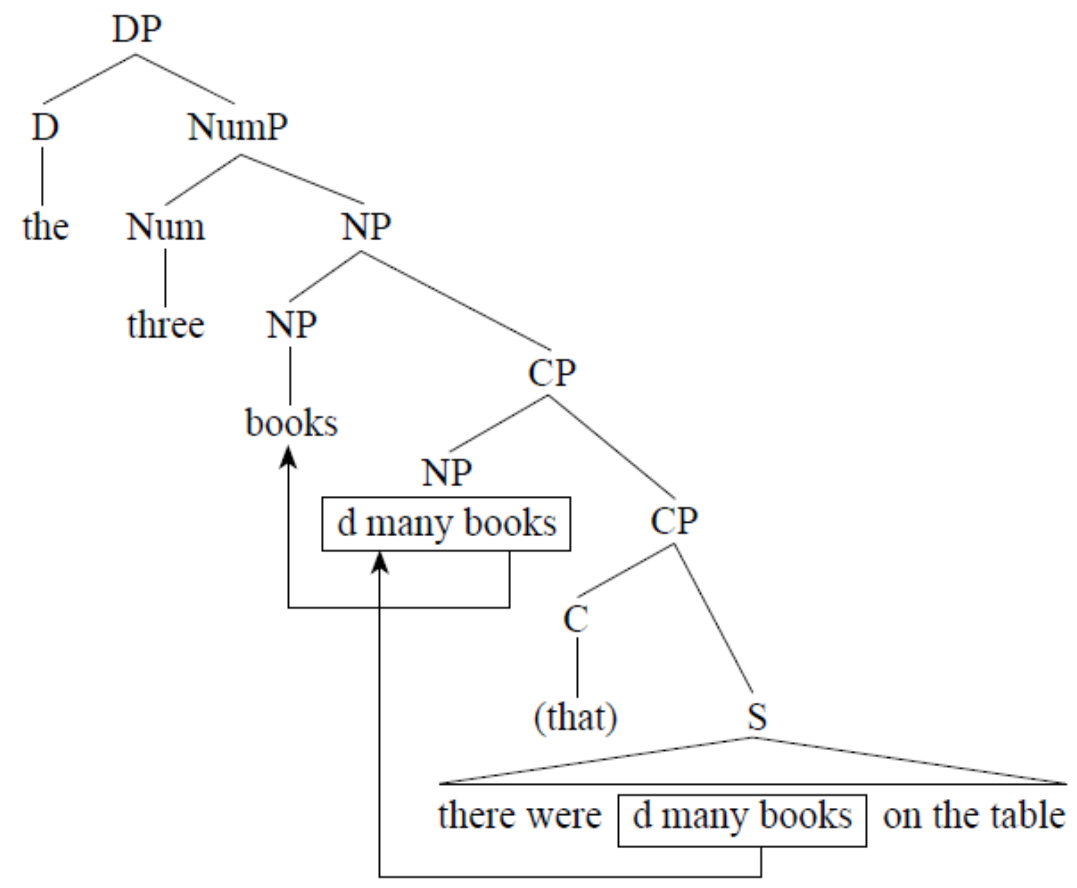

Segundo Grosu \& Landman (1998), as relativas de grau, como a representada no exemplo (25), apresentam uma expressão de grau, entendida pelos autores como uma expressão semântica [ $d$ many $x$ ], na qual o elemento representado por $d$ apresenta a noção da 
soma de todos os graus, essencial à leitura de maximalização; por sua vez, o elemento many apresenta a quantidade (soma) do nome relativizado; e, por fim, o nome relativizado é apresentado na posição do $x$. Para os autores, essa representação é a responsável pela possibilidade de leitura maximalizadora da relativa.

Observa-se, então, que, para Grosu \& Landman, o DegP, representado pela expressão [d many books], na derivação, é gerado no interior da oração relativa, na posição de base em que será interpretado. Segundo os autores, essa é uma característica essencial à compreensão das relativas de grau como maximalizadoras, e não uma leitura restritiva, visto que a expressão de grau, lida em sua posição de base, indica a leitura total do nome relativizado.

Em seguida, de sua posição de base, o DegP move-se para Spec de CP, como um NP. Dessa expressão de grau, retira-se o nome que será relativizado, subindo, somente o nome, para a posição de Spec-NP que estará já no domínio da oração matriz. Vale ressaltar, ainda, que, na visão de Grosu \& Landman (1998), a expressão de grau, entendida como um DegP, ao ser movida para a posição de Spec-CP, deixa vestígios pelas posições pelas quais passa. Esse DegP é foneticamente nulo, na visão dos autores.

Para Grosu \& Landman (1998), ainda, a leitura do nome relativizado ocorrerá na posição na qual foi gerada, no interior do CP-relativo, levando em conta as informações do DegP, garantindo, assim, a leitura de maximalização aplicada às relativas de grau de forma geral. Vale, por fim, destacar que o CP, na derivação proposta por Grosu \& Landman, segue o modelo Raising, apresentando a relativa como complemento do núcleo funcional D, cujo DP encontra-se no domínio da oração matriz.

Szczegielniak (2012) postula que o DegP é gerado no interior da relativa, assim como Grosu \& Landman (1998) e Grosu (2002), e que o movimento é na sintaxe aberta, por meio das operações de cópia e movimento, essenciais às derivações no momento atual do Programa Minimalista. Para o autor, essa cópia seria foneticamente apagada, para que não haja crash na derivação.

Segundo Szczegielniak (2012), as relativas de quantidade e as existenciais podem ser entendidas como apresentando as mesmas características, visto apresentarem mesma leitura a de maximalização do nome relativizado - e, para ele, a mesma derivação. Tanto Grosu (2002) quanto Szczegielniak (2012) entendem a derivação das orações relativas como semelhantes, com leitura explorada no capítulo seguinte. 


\subsection{Conclusões Parciais}

Nesta seção, analisamos as relativas de quantidade e as relativas existenciais que, seguindo Szczegielniak (2012), Grosu \& Landman (1998) e Grosu (2002), perfazem o subgrupo das relativas de grau, que apresentam leitura de gradação com relação ao nome relativizado. Nosso objetivo, ao apresentarmos as características das relativas de quantidade e das relativas existenciais era apresentar as semelhanças e as diferenças apresentadas entre essas duas leituras semânticas. Ambas, a nosso ver, apresentam uma leitura de quantificação máxima, que ocorre pela postulação de um sintagma de grau que é gerado no interior da relativa, movendo-se para Spec-CP, de onde será extraído o nome relativizado.

Entendemos, então, que a leitura de grau é unificadora com relação às relativas apresentadas, fato que nos permite entender que a diferença entre relativas de quantidade e relativas existenciais pode estar na posição em que o DegP será mergido na derivação, ou, ainda, que não há diferença de leitura entre as duas classificações, visto apresentarem a mesma noção de gradação com contagem máxima do nome a ser relativizado. Vale ressaltar que assumimos, aqui, a diferença de leitura existente entre as relativas de quantidade e as existenciais, buscando entendê-las como relativas de grau, com leitura, como dito, maximalizadora.

Ainda, percebe-se que a leitura maximalizadora só é possível quando ocorre em nomes que se apresentam com determinantes, o que fortalece a postulação de que a relativa funciona como complemento do núcleo do DP. Essa característica, postulada por Kayne (1994), Bianchi (1999) e De Vries (2002), entre outros, aplica-se tanto às relativas restritivas, trabalhadas de forma mais profunda no capítulo quatro, quanto às relativas maximalizadoras, exploradas no mesmo capítulo quatro.

Assim, entendemos que a relação que se estabelece entre a oração relativa, seja ela classificada como de quantidade, seja como existencial, é a mesma: uma leitura de quantificação universal, como discutiremos no capítulo seguinte, na apresentação das relativas maximalizadoras como a terceira classificação semântica para as relativas. 


\section{CAPÍTULO 4}

\section{A SEMÂNTICA DAS RELATIVAS}

\subsection{Introdução}

A semântica das orações relativas é uma área de trabalho extremamente prolífica e extensa que abarca uma série de interpretações diferentes. De maneira geral, a noção semântica é trazida a partir da relação que se estabelece entre as orações: a relação entre a oração relativa e o nome relativizado da oração matriz determina a classificação semântica dessa oração.

Como veremos a seguir, há duas classificações tradicionais para a semântica das relativas, a saber, "restritivas" e "apositivas". Minha proposta, neste trabalho, seguindo Grosu \& Landman (1998), Grosu (2002) e Szczegielniak (2012), é a inserção de uma terceira leitura para as relativas, a chamada "relativa maximalizadora", que apresenta uma leitura de quantificação/gradação total com relação ao nome apresentado.

Tradicionalmente, as maximalizadoras são classificadas semanticamente como relativas restritivas, pelo entendimento de que o conjunto denotado pela oração relativa é uma intersecção do conjunto denotado no nome relativizado. Nossa proposta de análise, já feita por Grosu \& Landman (1998) para as degree relatives do inglês, é a de analisar as relativas de grau do português com uma leitura de maximalização, diferente da atual classificação restritiva, atribuída a esse tipo de relativa. A classificação restritiva, que apresenta uma noção de intersecção de dois conjuntos, um denotado pelo nome relativizado e outro pela relativa, não pode, a nosso ver, abarcar as relativas de grau, uma vez que essas têm coincidência de conjuntos entre nome relativizado e relativa, apresentando uma leitura de quantificação máxima.

Para tanto, apresentam-se, neste capítulo, as classificações tradicionais das orações relativas quanto à sua semântica, partindo da classificação restritiva que, como dita anteriormente, é aplicada às relativas de grau; para a apositiva, que apresenta um comentário acerca no nome relativizado, com diferenças de derivação, como veremos no decorrer deste capítulo. Em seguida, contrastam-se as duas classificações para, só então, apresentar a classificação maximalizadora, baseada, principalmente, em Grosu \& Landman (1998), Grosu (2002) e Szczegielniak (2012). 


\subsection{A classificação semântica tradicional}

Tradicionalmente, as orações relativas são separadas em duas classificações: as orações relativas restritivas e as apositivas (ou "explicativas", conforme designação da Gramática Tradicional). As relativas restritivas são aquelas que se conectam diretamente ao nome relativizado, sem pausa prosódica, enquanto as apositivas apresentam-se separadas, na escrita, do nome relativizado por vírgulas - que podem ser duplas, isolando-as, quando encaixadas no meio da oração matriz, ou simples, quando vierem linearizadas no final da matriz. Vale ressaltar que, em português, as orações relativas ocorrem sempre pospostas ao nome relativizado.

De forma geral, a compreensão dessas classificações se dá por meio de uma relação entre conjuntos. Nessa forma de relação, entende-se que a relativa representa um dos conjuntos, enquanto o nome relativizado, inserido na oração matriz, representa o outro e, dependendo da relação que se estabelecerá entre esses dois conjuntos, há a classificação semântica da oração.

\subsubsection{As relativas restritivas}

A relativa restritiva, na visão de Bianchi (2002, p. 197), "é interpretada como um modificador intermediário entre o NP-alvo e a oração, possibilitando a restrição". Ainda para Bianchi (2002), as relativas restritivas denotam um conjunto que se relacionará semanticamente com o nome relativizado por meio de uma intersecção. Em outras palavras, haveria dois conjuntos distintos, como exposto acima, um representado pelo NP-alvo e outro pela relativa, sendo que a intersecção entre esses dois conjuntos determinaria a classificação como restritiva. É o que podemos visualizar no exemplo (1a), a seguir, com (1b) apresentando a derivação da relativa no modelo Raising (Kayne, 1994; Bianchi, 1999; De Vries, 2002), aqui adotado como modelo base.

(1) a. A professora conversou com os colegas que não se saíram bem nas avaliações dos alunos.

b. [DP $\left[\mathrm{D}^{\prime}\right.$ os $\left[\mathrm{CP}\left[\mathrm{DP}-\mathrm{Rel}[\mathrm{NP} \text { colegas }]_{\mathrm{k}}\left[\mathrm{D}^{\prime} \text {-Rel que } t_{k}\right]\right]_{\mathrm{i}}\left[\mathrm{C}^{\prime} t_{i}\right.\right.$ não se saíram bem nas avaliações dos alunos]]]]

No exemplo (1), em derivação fundamentada em De Vries (2002), percebe-se que o DP-relativo, que abarca o nome relativizado e o pronome relativo, é alçado de sua posição de 
base, no interior da oração relativa, para a posição de Spec-CP. Há, ainda, movimento interno a esse DP-Rel, visto que, como o nome desempenhará função sintática no interior da oração matriz, o NP [colegas] será movido para a posição de Spec do DP a que pertence para valorar os traços relativos à função que desempenhará no interior da oração matriz. Seguindo Kayne (1994), Bianchi (1999) e De Vries (2002), percebe-se o CP-relativo em posição de complemento do núcleo do DP.

Além disso, no exemplo (1a), é possível perceber que a restrição seria interpretada da seguinte maneira: no universo do discurso - e isso é extremamente importante de se levar em conta - do conjunto de colegas possíveis, há somente alguns que foram procurados pela professora para conversar. Estes são os que não se saíram bem nas avaliações dos alunos, fato que restringiria o NP-alvo da relativização. A restrição seria causada pela noção de que há, entre os dois conjuntos, uma intersecção. Percebe-se, então, que a compreensão da sentença depende da análise tanto do NP-Alvo quanto da informação trazida pela relativa. Segundo Comrie (1981, apud Alexandre, 2000), the head [of the restricting clause] in itself has a certain potential range of referents, but the restricting clause restricts this set by giving a proposition that must be true of the actual referents of the over-all construction. ${ }^{12}$ Essa ideia reforça a relação semântica que se estabelecerá entre a relativa e o nome a ser relativizado. Seguindo a mesma forma de pensamento, Corrêa et al. (2012, p. 173), entendem que

\begin{abstract}
orações relativas restritivas são instrumentais para a referência específica, uma vez que apresentam um atributo definidor de uma subclasse denotada pelo nome. Inseridas em um DP definido, promovem a integração de informação necessária para a recuperação do referente pretendido pelo falante.
\end{abstract}

Ainda sobre a relação estabelecida entre as restritivas e o nome relativizado, Medeiros Júnior (2014, p. 33) aponta que as

Orações relativas restritivas apresentam uma lacuna em seu interior e a essa lacuna
associa-se o deslocamento de um constituinte wh- (que nesse caso é o pronome
relativo) para uma posição fronteiriça da sentença, de onde esse elemento relativo
pode acessar o nominal (antecedente) na sentença matriz e operar sobre ele
atribuindo-lhe as propriedades semânticas que a relativa contém.

Ainda para o autor, a relação de natureza semântica das restritivas é excludente, visto que são modificadores do nome a que se conectam. Tal conexão pode ser entendida, em (1), como a intersecção entre o conjunto denotado pelos professores e o conjunto denotado pelos

12 "O nome relativizado [da relativa restritiva] tem, em si, uma gama potencial de referentes, mas a oração relativa restringe este conjunto, dando uma proposição que deve ser, sobretudo, verdadeira dos referentes reais da construção" (tradução livre). 
avaliados pelos alunos. Nas palavras de Medeiros Júnior (2014, p. 33), no caso das restritivas temos

as orações relativas atuando no domínio de referência da expressão nominal antecedente. Dizendo de outra maneira, a oração relativa chamada restritiva (em termos semânticos) cria um subconjunto do conjunto denotado pela expressão nominal que lhe serve de antecedente - atuando, portanto, de forma excludente.

A relação estabelecida entre o nome relativizado e a oração relativa é entendida, ainda para Corrêa et al. (2012), como uma relação anafórica que, segundo as autoras, requer a recuperação do evento passado e retomado pela oração.

Semanticamente, é interessante notar que as orações restritivas não são capazes de restringir um único exemplar da espécie, como os nomes próprios. Segundo Medeiros Júnior (2014), outra característica das orações restritivas é o fato de essas orações não poderem modificar quaisquer outros sintagmas, somente os DPs. Em português, para Medeiros Júnior (2014) e Kenedy (2014), as relativas restritivas não são licenciadas a ocorrerem quando o nome a ser relativizado for um nome próprio, sem a presença de um artigo. Portanto, os exemplos (2a) e (2c) são considerados agramaticais em português.
a. *João que trouxe as coisas do supermercado mora no apartamento vizinho.
b. João, que trouxe as coisas do supermercado, mora no apartamento vizinho.
c. *Brasília que todos gostariam de conhecer é uma cidade admirável.
d. Brasília, que todos gostariam de conhecer, é uma cidade admirável.

Nos exemplos anteriores, percebe-se que, em (2a), há agramaticalidade causada pelo uso de uma relativa restritiva ligada a um nome próprio, construção proibitiva em língua portuguesa. Por outro lado, em (2b), com a utilização das vírgulas, pausa prosódica necessária a essa classificação, temos uma construção gramatical que não apresenta problemas de construção. Vale ressaltar, apesar do exposto acima, que a utilização de um artigo definido antes do nome relativizado, ainda que este seja um nome próprio, licencia a utilização da restrição. Nesse caso, a restrição é, inclusive, a construção preferida, como podemos observar em (3).

(3) a. O João que trouxe as coisas do supermercado mora no apartamento vizinho.

b. A Brasília que todos gostariam de conhecer é uma cidade admirável. 
Nos exemplos (3), segundo Kenedy (2014) e Medeiros Júnior (2014), seguindo Bianchi (1999), a utilização do artigo traz, ao invés de uma relação de definição, uma ampliação da significação do nome relativizado, que é modificado e passa a ter uma leitura de existência de mais de uma Brasília e de mais de um João. Em (3a), depreende-se que, no universo do discurso, há mais de uma pessoa chamada João e que a relativa está servindo de especificação para esse nome, dando a ele uma característica própria. O mesmo acontece em (3b), em que temos a possibilidade de existência de mais de uma configuração da cidade de Brasília. O leitor não compreenderia a existência de mais de uma cidade chamada Brasília, mas de mais de uma configuração de cidade na própria cidade.

\subsubsection{Orações relativas apositivas/explicativas}

A relativa apositiva, por sua vez, "modifica todo o NP-alvo, não contribuindo para a restrição" (Bianchi, 2002, p. 197). Nesse caso, há uma coincidência entre os dois conjuntos: o todo do NP-alvo é relativizado, pela mesma totalidade encontrada na relativa. É o que podemos perceber no exemplo (4a), a seguir. Em (4b), temos a derivação da oração relativa apositiva de forma semelhante à apresentada nas restritivas, com a diferença, para Kayne (1994), do movimento, em LF, do IP da relativa que passará a ocupar a posição de Spec-DP, permitindo a leitura de coincidência entre os conjuntos.

(4) a. A professora conversou com os colegas, que não se saíram bem nas avaliações dos alunos.

b. $\left[\mathrm{DP}\left[\mathrm{D}\right.\right.$ ' os $\left[\mathrm{CP}\left[\mathrm{DP}-\mathrm{Rel}[\mathrm{NP} \text { colegas }]_{\mathrm{k}}\left[\mathrm{D}^{\prime} \text {-Rel que } t_{k}\right]\right]_{\mathrm{i}}\left[\mathrm{C}^{\prime}\right.\right.$ [IP $t_{i}$ não se saíram bem nas avaliações dos alunos]]]]]

Em (4b), fundamentada em De Vries (2002), a derivação, como dito anteriormente, ocorre da mesma forma que a derivação das restritivas. Percebe-se, então, que o DP-relativo, em que se encontram o nome relativizado e o pronome relativo, é alçado de sua posição de base, no interior da oração relativa, para a posição de Spec-CP. Em seguida, o NP [colegas] move-se para a posição de Spec do DP a que pertence, para termos a linearização do enunciado. Vale ressaltar que, segundo Kayne (1994), como dito anteriormente, há um movimento adicional, em LF, do IP [não se saíram bem nas avaliações dos alunos], para que possa estabelecer-se a leitura apositiva, marcada, na escrita, pela vírgula. 
Assim, em (4a), os conjuntos denotados, tanto pelo DP-alvo [os colegas] quanto pela relativa [que não se saíram bem nas avaliações dos alunos], seriam os mesmos, ou seja, o conjunto de colegas é exatamente igual ao dos que não se saíram bem nas avaliações. Discursivamente, compreendem-se os dois conjuntos como iguais. Para Grosu \& Landman (1998), haveria, aí, uma relação anafórica, visto que a relativa é correferencial ao NP-Alvo.

O mesmo fato aponta De Vries (2002), para quem ocorre, no caso da leitura apositiva, uma modificação somente no universo do discurso. Para o autor (2002, p. 24) since the relative is anaphorically linked to the antecedent at a discourse level only [...]; hence the semantic relation is indirect. ${ }^{13}$ Segundo Marchesan (2012), seguindo Kayne (1994) e De Vries (2002), no caso das apositivas, o termo mais importante da interpretação é o nome relativizado, visto haver simetria entre os dois conjuntos, o denotado pelo nome relativizado e o denotado pela relativa.

Outra característica bastante discutida com relação às orações relativas apositivas é a possibilidade de que as orações com essa leitura podem ser enumeradas, e isso corresponde a dizer que há a possibilidade de duas ou mais orações estarem relacionadas a um mesmo nome relativizado. Para Grosu \& Landman (1998), esse fato não ocorre com as maximalizadoras, servindo de diferencial na identificação das orações. É o que podemos perceber no exemplo (5), traduzidos de Grosu \& Landman (1998, p. 148), e (6) adaptado de Grosu \& Landman (1998), apresentados a seguir.

*The one sailor that there was on the boat that there had been on the island died in the explosion.

'*O único navegador que havia $e c$ no barco que tinha estado na ilha morreu $e c_{i}$ na explosão'.

(6) O navegador, que estava $e c$ no barco, que tinha estado na ilha, morreu $e c_{i}$ na explosão.

No exemplo (5) temos um exemplo de enumeração de relativas considerado, por Grosu \& Landman (1998), como agramatical. A enumeração do exemplo (5) é agramatical, segundo os autores, porque as relativas [que havia ec no barco] e [que tinha estado na ilha morreu $e c_{i}$ na explosão] relacionam-se com o DP [o único navegador], não sendo gramaticais, em PB, por não conseguirem se relacionar com o nome relativizado. Isso aconteceria, segundo os autores, pela leitura interna à relativa do nome relativizado, fato que será

\footnotetext{
13 "Como a relativa é ligada anaforicamente somente no universo do discurso [...], a relação semântica é indireta"
} (tradução livre). 
explorado ainda neste capítulo. Por outro lado, o exemplo (6) é considerado gramatical, no $\mathrm{PB}$, pois a leitura do nome relativizado é externa ao $\mathrm{CP}$, o que permite a leitura explicativa.

É possível, então, comparar-se a relação existente nessas duas primeiras classificações ao aplicar-se um teste proposto por Grosu (2002), no qual se separam as duas orações e se substitui o elemento-QU por um pronome. No caso das apositivas, percebe-se a igualdade entre os conjuntos proposta pela teoria.

(7) A professora conversou com os colegas. Eles não se saíram bem nas avaliações dos alunos.

Em (7), o pronome (“eles") deve ser interpretado exatamente como referencial de "os colegas", integralmente. Para Grosu (2002), as apositivas formam um constituinte único com todo o DP, enquanto, no caso das restritivas, a relação sintática seria estabelecida apenas com o núcleo nominal constante do DP, não englobando o determinante.

Se o teste proposto por Grosu fosse aplicado ao exemplo (1) - "A professora conversou com os colegas que não se saíram bem nas avaliações dos alunos" -, que apresenta uma relativa restritiva, não haveria correspondência entre o pronome e o DP-Alvo, visto que são dois conjuntos diferentes:

(8) *A professora conversou com os colegas. Eles não se saíram bem nas avaliações dos alunos (na leitura restritiva).

A interpretação, nesse caso, seria obrigatoriamente igual à aplicada à relativa explicativa, uma vez que o pronome "eles" parece retomar todo o conjunto de colegas de tal professora, e não somente a intersecção de professores encontrada na leitura restritiva da oração. Em (8), para o autor, há a comprovação de que há c-comando entre o DP-Alvo e o elemento-QU, em que o segundo é c-comandado pelo primeiro, formando-se uma indexação sintática gerada pelo compartilhamento de traços. É a mesma vinculação que ocorre nas maximalizadoras, com diferenças na relação, como será possível perceber na continuação desta dissertação. 


\subsubsection{Diferença entre as relativas restritivas e as apositivas}

A partir da discussão anterior, envolvendo as duas leituras tradicionalmente atribuídas às relativas, é interessante que estabeleçamos algumas diferenças entre as relativas restritivas e as explicativas. Para Negrão (1992), há diversas diferenças entre as orações restritivas e apositivas, tanto sintáticas quanto semânticas, fato responsável por produzirem condições de verdade distintas e diferentes.

(9) a. Os títulos que foram criados pelos estudantes ficaram muito bons.

b. Os títulos, que foram criados pelos estudantes, ficaram muitos bons.

Seguindo o pensamento de Negrão (1992), as condições de verdade associadas aos exemplos (9a e b) são: em (9a), no universo do discurso, há somente alguns títulos com a propriedade de terem sido criados pelos estudantes; enquanto em (9b) a ideia é diferente, pois, no universo do discurso, há somente os títulos que apresentam a propriedade de terem sido criados pelos estudantes.

Além da noção da relação de conjuntos, explorada anteriormente, Negrão (1992) apresenta outras características que distinguem as duas formas de classificação semântica das relativas. Dentre elas, é possível destacar a possibilidade de alguns sintagmas quantificados, essencialmente com o quantificador universal "todo", funcionarem como pivô externo de sentenças relativas. Para a autora, a aceitabilidade de relativização por orações restritivas é maior do que a aceitação das apositivas. Segundo a autora (1992, p. 85), os exemplos a seguir servem de demonstração dessa forma de análise.

(10) a. Todo aluno que gosta de participar das atividades esportivas tem que trazer seu próprio material.

b. *Todo aluno, que gosta de participar das atividade esportivas, tem que trazer seu próprio material.

Para entender a agramaticalidade de (10b) é preciso comparar sua interpretação nãorestritiva à interpretação restritiva de (10a). Em (10a), o quantificador todo opera sobre o conjunto de alunos interessados em participar das atividades esportivas e diz que todos os membros desse grupo devem trazer seu próprio material. Em (10b), todo opera sobre o conjunto de alunos e diz que o total de elementos desse conjunto tem a propriedade de gostar de participar das atividades esportivas, o que é muito estranho. 
É o mesmo que apresenta De Vries (2002), para quem a diferenciação entre as relativas restritivas e as apositivas também apresentaria algumas particularidades já na relação entre o determinante do DP e a relativa.

(11) O livro $($,$) que foi adotado naquela escola ($,$) é completamente digital. (Restritiva/Apositiva)$ (12) Qualquer livro que seja adotado naquela escola deverá ser digital. (Restritiva)

Percebe-se, nos exemplos (11) e (12), que a utilização de um quantificador só licencia orações restritivas, enquanto o especificador definido licencia classificações restritivas ou explicativas.

Grosu (2002) afirma, apresentando a diferença entre as restritivas e as apositivas, que a principal diferença entre essas duas leituras está situada na forma como o determinante externo e o nome relativizado estabelecem relação com os elementos-QU apresentados. Vale lembrar que, para Grosu (2002), a relação da relativa estabelece-se com DPs. Assim, para o autor, as restritivas, em uma relação semântica, relacionam-se com o núcleo nominal, relativizado, enquanto as apositivas relacionam-se com todo o DP. A informação está relacionada com o DP contendo o determinante e o nome relativizado.

\subsection{As relativas maximalizadoras: a terceira possibilidade de leitura}

A noção de maximalização foi discutida, a fundo, em importante artigo publicado por Grosu \& Landman em 1998. Antes desse artigo, a noção de maximalização já havia sido discutida superficialmente por Carlson (1977) e, dez anos depois, por Heim (1987). Os dois últimos autores apresentam, nas respectivas obras, análises acerca das relativas de quantidade e existenciais, indicando haver uma leitura semântica distinta para elas. Para De Vries (2002), a leitura maximalizadora ocorre sempre que o conteúdo da oração relativa é mais importante que o nome relativizado, visto que este será lido no interior do $\mathrm{CP}$, e não externamente, na posição em que é linearizado.

Para Grosu \& Landman (1998), a classificação semântica em sua visão tradicional não consegue abarcar a variedade de interpretações que são trazidas pelas relativas, visto que, de forma geral, nem sempre há intersecção de conjunto ou simples coincidência de conjuntos, como defendemos nesta pesquisa. É o que acontece no exemplo (13), a seguir, retomado do texto. 
(13) I took with me the three books that there were on the table. Eu trouxe comigo os três livros que havia sobre a mesa. 'Eu trouxe comigo os três livros que havia sobre a mesa'. (G\&L, 1998, p. 128)

Em (13), segundo a leitura dos autores, não há uma intersecção entre os conjuntos denotados pela relativa e pelo nome relativizado livros. Em outras palavras, não é possível entendermos, a partir da leitura do exemplo, que, no universo do discurso, há mais do que os três livros que foram trazidos. A leitura é a de quantificação, de totalidade. No universo do discurso, foram trazidos os três livros que estavam sobre a mesa, em uma noção de que todos os livros que havia sobre a mesa foram trazidos.

Para os autores, a análise feita com relação à leitura das restritivas e apositivas deveria ser repensada a partir da posição em que é interpretado o nome relativizado. Atualmente, na visão dos autores, as relativas restritivas e apositivas são interpretadas de forma igual, ou seja, apresentam interpretação de nome relativizado de forma interna. Na visão de Grosu \& Landman (1998), essa seria uma interpretação errônea, uma vez que ambas são interpretadas externamente ao $\mathrm{CP}$, enquanto as maximalizadoras, que apresentam, como dito anteriormente, leitura de gradação, são interpretadas internamente ao $\mathrm{CP}$, diferenciando-se das demais leituras semânticas.

Assim, para os autores, a diferença de leitura externa ou interna do nome relativizado está relacionada diretamente à importância da informação veiculada. Nas apositivas, o material externo é o elemento mais importante dessa relação, uma vez que a ligação entre o antecedente e a relativa ocorre anaforicamente somente no nível do discurso. Assim, nas apositivas, a construção semântica da relativa é feita externamente ao CP. Para os autores, essa diferença de leitura é apresentada somente por meio de uma noção semântica, sem apresentar diferenças na derivação.

O mesmo ocorre, segundo Grosu \& Landman (1998), com as relativas restritivas. A diferença entre as duas leituras, para os autores, estaria na importância compartilhada entre a relativa e o nome relativizado. O nome relativizado, nesse caso, apresentaria importância em sua posição mais externa, antecedendo a relativa.

Vale ressaltar, neste ponto, que a noção de interpretação interna ou externa do nome relativizado é uma operação sintático-semântica relacionada à posição em que esse nome será compreendido, se na posição linearizada ou na posição de base, ou seja, no local em que foi 
gerada. No caso das relativas maximalizadoras - todas as de grau, em nossa perspectiva -, tem-se a interpretação na posição em que foi gerada, ou seja, no interior da relativa. Assim, em (14), a seguir, temos a interpretação do nome relativizado no interior da relativa.

(14) Os alunos estudaram o conteúdo que estava em seu caderno.

Em (14), um enunciado construído com uma relativa existencial, percebe-se que o nome relativizado, [conteúdo] é compreendido no interior da relativa, com uma noção de que todo o conteúdo que estava no caderno foi estudado pelos alunos. Assim, a relativa apresenta uma leitura interna, diferente da que pode ser encontrada nas relativas restritivas e apositivas, entendidas por Grosu \& Landman (1998), como relativas de leitura externa, sendo as apositivas as mais externas e as restritivas com uma leitura menos externa, mas ainda não interna. Assim, em (15) e (16), uma restritiva e uma apositiva, respectivamente, a leitura/compreensão do nome relativizado se daria fora do CP-relativo, fator que, para os autores, as diferenciaria das relativas maximalizadoras e permitiria a enumeração dessas orações, fato não encontrado nas relativas de grau.

(15) O professor conversou com os estudantes que estavam participando da olimpíada.

(16) O professor parabenizou os estudantes, que estavam na sala durante o exame.

Em (15) e (16), para Grosu \& Landman (1998), a interpretação/leitura dos nomes relativizados se daria fora do domínio do CP-relativo, com compreensão relacionada à posição de linearização, não de geração. Para De Vries (2002), a diferença entre a leitura interna e a externa não está relacionada a um processo sintático, mas sim a um processo semântico. $\mathrm{O}$ autor entende que a leitura se dá pelo grau de importância apresentado pelos conjuntos envolvidos. Assim, nos exemplos (15) e (16) a leitura se dá de forma externa ao CP-relativo, pois o ente mais importante envolvido é o nome relativizado, não a informação trazida pela relativa. Essa, na visão do autor, é a diferença entre as classificações tradicionais e a classificação maximalizadora.

Dessa forma, a proposta dos autores é a separação em interpretações de categoriaexterna, nas quais se encaixariam as tradicionais restritivas e apositivas; e em interpretação de categoria-interna, na qual se encaixam as maximalizadoras. Nas palavras de Grosu \& Landman (1998, p. 126), “essa dicotomia toma como critério se a categoria de construção da 
relativa (que é o nome comum, ou NP, ou construções DP) é semanticamente feita fora ou dentro do CP".

No caso das relativas de grau, tratadas por Grosu \& Landman (1998, p. 127) como relativas com leitura maximalizadora,

We will argue that part of the semantics of these constructions is a CP-internal maximalization operation. Whatever CP-external material is syntactically present is either interpreted $\mathrm{CP}$-internally or by and large predictable from the semantic interpretation of the $\mathrm{CP}$ after maximalization. ${ }^{14}$

Para Grosu \& Landman (1998), no caso dessas orações maximalizadoras, haveria um sintagma de grau - DegP - responsável pela maximalização da leitura. Tal sintagma, representado por uma expressão [d many $x$ ], seria gerado no interior do CP-relativo e, de lá, movido para Spec-CP, de onde o nome relativizado, representado por $x$, seria movido para a posição de Spec-NP, com representação a seguir, adaptada dos autores (1998, p. 131) e com retomada do exemplo (13).

(17) [IP Eu trouxe comigo] [DP [D os três] [NP livros][CP [NP ŁDegp-d many livres] [CP [C que [IP havia [Degp sobre a mesa]]]]]].

Em (17), a expressão de grau - DegP -, entendido pelos autores como o responsável pela leitura de quantificação gradativa, é gerado no interior do $\mathrm{CP}$, como dito anteriormente, e seria apagado foneticamente na posição em que foi gerado, para que não ocorra agramaticalidade em PF. É interessante notar que, após esse movimento, para Spec-CP, há movimento do nome a ser relativizado para a posição do NP que ocupa a posição de complemento do DP que se liga à oração matriz. Para os autores, a expressão [d many livros] é crucial para a leitura maximalizadora, sendo o $d$ a representação do conjunto de todas as gradações, um grau máximo. Além disso, many, na visão dos autores, representa uma soma (quantitativa) e livros, nome relativizado, sobre a mesa.

A derivação, representada em (17), poderia ser explicada da seguinte maneira:

Following Bianchi (1995) and Kayne (1994) (and incorporating elements from earlier literature, including Carlson 1977b), we assume the following movement operation: the position of the gap in the relative clause contains a degree phrase $d$ many books which is moved to the Spec of CP. From this position the head noun books is moved out of the CP to the external head position in the dominating NP.

14 "Temos argumentado que a semântica dessas construções é uma relação de maximalização interna. Seja qual for o material externo ao $\mathrm{CP}$, ele é analisado sintaticamente interno ao $\mathrm{CP}$, após a maximalização" (tradução livre). 
The head noun is phonologically realized; the copies of the degree phrase are phonologically null (Grosu \& Landman, p. 130). ${ }^{15}$

No caso de nossa derivação, percebe-se que o sintagma de grau é movido, inicialmente, para a posição de Spec-CP, de onde somente o nome que será relativizado é extraído para fora do $\mathrm{CP}$, como apontam os autores, para uma posição no domínio do DP. O DegP é apagado foneticamente para evitar a agramaticalidade do enunciado.

Semanticamente, Grosu \& Landman (1998) indicam que a leitura de quantificação trabalha com a verdade de que, se sobre a mesa houvesse os livros $a, b$ e $c$, todos eles foram trazidos, sem que houvesse quaisquer outros livros à disposição para que ocorresse a leitura de restrição, comum nos casos de leitura tradicional. Em outras palavras, para os autores, não há possibilidade de leitura restritiva, uma vez que todos os livros que estavam sobre a mesa foram trazidos. Segundo os autores (1998, p. 130), degree relatives do not combine with the head noun through intersection; rather, the head noun information plays the role of a sortal inside the degree relative. ${ }^{16}$

É o que se pode notar na representação em (18b), que apresenta exemplo criado por mim em (18a). Percebe-se, então, a mesma leitura proposta por Grosu \& Landman.

(18) a. O menino derramou a água que estava no copo do professor.

b. [IP O menino derramou] [DP [D a] [NP água][CP [NP ŁDegP-d many água] [CP [C que [IP [Degp-d many água] estava no copo do professor]]]]]].

No exemplo (18b), encontra-se a derivação, baseada na proposta de Grosu \& Landman (1998), para o enunciado em (18a). A leitura que o exemplo (18), em sua totalidade, permite, é a de que toda a água que havia no copo do professor foi derramada pelo menino, não permitindo uma leitura, a meu ver, que apresente a ideia de que, no universo do discurso, havia mais água que não foi derramada pelo menino, como apresentaria a leitura restritiva que, como dito anteriormente, é onde se encaixam as maximalizadoras em uma classificação tradicional.

\footnotetext{
15 "Seguindo Bianchi (1995) e Kayne (1994) (e incorporando elementos anteriores, incluindo Carlson 1977b), assumimos a seguinte operação de movimento: a posição do gap na oração relativa contem um sintagma de grau $d$ many books que se move para Spec-CP. Dessa posição, o nome cabeça livros é movido para fora do CP, na posição de cabeça externa, no domínio de NP. O nome cabeça é realizado foneticamente; a cópia do sintagma de grau é foneticamente nula" (tradução livre).

16 "Relativas de grau não se combinam com o nome cabeça por meio de uma intersecção; por outro lado, a informação do nome cabeça apresenta uma categoria dentro da relativa de grau" (tradução livre).
} 
Nos exemplos (17) e (18), percebemos que a relação de leitura da relativa permanece a mesma, independente do nome relativizado ser um nome contável ou incontável, parecendo, a mim, não haver diferença de relativização fundamentada nessa característica do nome. A leitura de maximalização é modificada, somente, se não houver determinante ligado ao nome relativizado, como ocorre abaixo, em (19).

(19) a. Eu trouxe comigo livros que havia sobre a mesa.

b. [IP Eu trouxe comigo] [NP [N livros][CP [NP [ $\mathrm{CP}_{\mathrm{CP}}$ que [IP havia sobre a mesa]]]]]].

Em (19), a leitura com a ausência do determinante é diferente da leitura quantificadora que encontramos em (17), visto que a compreensão permitida pelo enunciado é a de que havia livros sobre a mesa e que foram trazidos. Ainda assim, não é possível afirmar que foram trazidos todos os livros que, no universo do discurso, havia sobre a mesa ou se havia outros livros que ali foram deixados.

Neste caso de comparação entre os exemplos (17) e (19), parece haver uma confirmação parcial da teoria de Kayne (1994) e Bianchi (1999), visto que a relativa de grau apresenta essa leitura quando há ocorrência de um D a ser complementado, no caso, pelo CPrelativo. Seria o chamado "efeito de definitude", postulado por Grosu \& Landman (1998), como essencial a essa leitura de maximalização. Para os autores, seguindo Carlson (1977), o efeito de definitude, tido como essencial ao processo de maximalização, é causado pelos nomes que apresentam determinantes definidos ou universais.

Nessa perspectiva, é interessante apresentar, ainda que de maneira rápida, o que é definitude dentro de uma perspectiva linguística. Para Aguiar (2013, p. 25), “definitude é uma noção que está intimamente associada ao uso do artigo definido (ou de um determinante) em línguas como o inglês, húngaro, português e espanhol”. Percebe-se, a partir do exemplo trazido em (19), que a ausência do elemento definido impede a leitura de maximalização que havia com a colocação do definido antes do nome relativizado.

Para Grosu (2002), a noção de definitude é essencial para a leitura que essas orações apresentarão. Assim, as noções semânticas das relativas estariam diretamente relacionadas aos traços apresentados em cada uma delas. Assim, o autor assume que as relativas que apresentam somente o traço [REL] são analisadas e interpretadas como apositivas. Na visão 
do autor, esse traço nasce em $\mathrm{C}$ e caracterizará, quando sozinho, o nome relativizado nas apositivas.

Seguindo essa forma de pensamento, Grosu (2002) postula que a diferença de significação existente entre as relativas, seja em uma leitura tradicional, seja em uma leitura maximalizadora, se dá pela inserção de traços semânticos distintos que, acumulados, modificam a leitura das orações.

Diante disso, o autor apresenta a noção de que, quando se é adicionado o traço semântico [PRED], gera-se uma oração semanticamente entendida como restritiva. Para o autor, esse traço adicional seria gerado juntamente ao traço [REL], também em C. O traço [PRED], indicado acima, garantiria a necessidade de abstração da relativização, fato capaz de gerar a intersecção necessária a essa leitura.

Por fim, o autor indica que, nas maximalizadoras, tal leitura seria garantida, ainda, pela entrada de mais um traço, também em C, aparecendo como um determinante, seja ele um artigo definido, seja um universal, capaz de apresentar a ideia de um indivíduo plural único, responsável pela maximalização da leitura e apresentando-se ligado diretamente à ideia de definitude.

Tal traço, representado pelo autor como [DEF] - como dito anteriormente, um artigo definido ou um universal -, é indicado como capaz de, em relação a um nome relativizado, distingui-lo, quanto à gradação. A relação, então, é estabelecida quase que completamente pela presença do artigo definido. Essa visão é bastante interessante e corrobora o que discutimos anteriormente, quando analisamos a ideia, postulada por Carlson (1977) e Grosu \& Landman (1998), de que as orações relativas de grau, entendidas por nós como maximalizadoras em todas as suas ocorrências, não são capazes de ser geradas sem um elemento que as defina ou quantifique. Assumimos que as relativas de grau do português, entendidas por nós, como discutido anteriormente, como subclasse formada pelas relativas existenciais e de quantidade, ocorrem somente quando acompanhadas de um determinante, representado por um artigo ou um determinante universal.

$\mathrm{O}$ autor ainda argumenta que, nas relativas maximalizadoras, o CP não é interpretado como uma intersecção do nome relativizado, mas como um núcleo maximalizado. Ou seja, com a soma dos três traços indicados por Grosu (2002), obtém-se a leitura de maximalização. $\mathrm{O}$ autor ainda ressalta que, para que a leitura seja aplicada corretamente, a interpretação dos 
traços [DEF] e [PRED] tem de ocorrer simultaneamente, sem que haja a comparação de um set de indivíduos a um único objeto.

A postulação de Grosu (2002), apresentada por meio de uma relação de traços semânticos, carece de apresentação de uma formalização sintática. Esse é um dos objetivos futuros desta pesquisa - formalizar a relação de grau que se estabelece entre a relativa e o nome relativizado, a partir da relação de traços apresentados.

Para Szczegielniak (2012), baseando-se nas relativas de quantidade e as adjetivais do espanhol, as relativas de grau, com leitura maximalizadora, seriam derivadas via movimento manifesto do DegP. Para postular sua teoria, o autor utiliza dois exemplos, reproduzidos abaixo, acerca dos quais apresenta leituras possíveis e impossíveis. Os exemplos, retirados de Szczegielniak (2012, p. 255), estão representados a seguir em (18) e (19).

(20) It would take days to drink some champagne they spilled that evening. EXP iria levar dias beber algum champanhe eles derramaram aquela noite.

'Levaríamos dias para beber um pouco do/todo/o champanhe que eles desperdiçaram naquela noite.'

(21) Juan no entendió lo hermosa que era la novela.

'João não entendeu o quão boa era a novela'

Com relação ao exemplo (20), o autor argumenta que a leitura possível (e única possível), seria uma leitura de quantificação com relação ao nome relativizado. Para o autor, seria vetada a interpretação de que o nome relativizado tratava de uma quantidade de champanhe atual, sem relação com o momento em que houve o desperdício do líquido. Aqui, vale a pena retomar a ideia de que esse mesmo exemplo, retirado de Heim (1987) e analisado por Grosu \& Landman (1998), apresenta, para esses últimos autores, a leitura de grau, com noção expandida de identificação da substância envolvida, como apresentei no capítulo três, ao analisar as diferenças existentes entre as relativas de quantidade e as existenciais.

No exemplo (21), por sua vez, Szczegielniak (2012) aponta como verdade a ideia de que Juan não entendeu a extensão da beleza da novela, não a ideia de que a novela não era bela, postulando que há uma relação de gradação, ainda que não trazida por uma relativa, mas com comportamento semelhante quanto à quantificação da beleza. Para o autor, em (20) e (21), a maximalização se dá pela mesma derivação, com o movimento do DegP, de sua posição de base, para Spec-CP, na sintaxe manifesta e com a configuração de maximalização. 
Ainda para o autor, a relação é semelhante nas comparativas, com a diferença de que, nos exemplos, o sintagma de grau move-se abertamente, enquanto nas comparativas, tal movimento se dá de forma encoberta e não para Spec-CP, pousando fora do domínio do CP.

Para Szczegielniak (2012), o comportamento das existenciais é semelhante ao comportamento apresentado pelas relativas de quantidade, formando, ambas, as relativas de grau. O autor ainda aponta que, no caso da derivação das relativas de grau, há duas principais teorias concorrentes: a derivação correspondente e o alçamento do nome cabeça. Para ele, a diferença entre as duas está na relação que o nome relativizado estabelecerá com o gap no interior do modificador. Essa relação pode se dar por movimento ou via elipse, com a geração de uma cópia idêntica que será apagada no momento do Spell-out.

Tanto Grosu \& Landman (1998) quanto Carlson (1977) adotam a ideia de que há movimento desse nome, com vestígio no local de base de onde foi movido. Grosu \& Landman postulam que o nome cabeça pousa fora do $\mathrm{CP}$, com relação similar à apresentada por Kayne (1994) em seu modelo Raising. Tal modelo postula, como apresentam outros modelos, que o nome cabeça pode e vai ser reconstruído em sua posição de base, visto ser um exemplo de movimento-A'. Szczegielniak (2012, p. 258) apresenta a derivação em (22), baseada na postulação de Grosu \& Landman (1998).

(22) Derivação da relativa encontrada em It will take us the rest of our lives to drink the champagne that they spilled that evening. (Szczegielniak, 2012, p. 258).

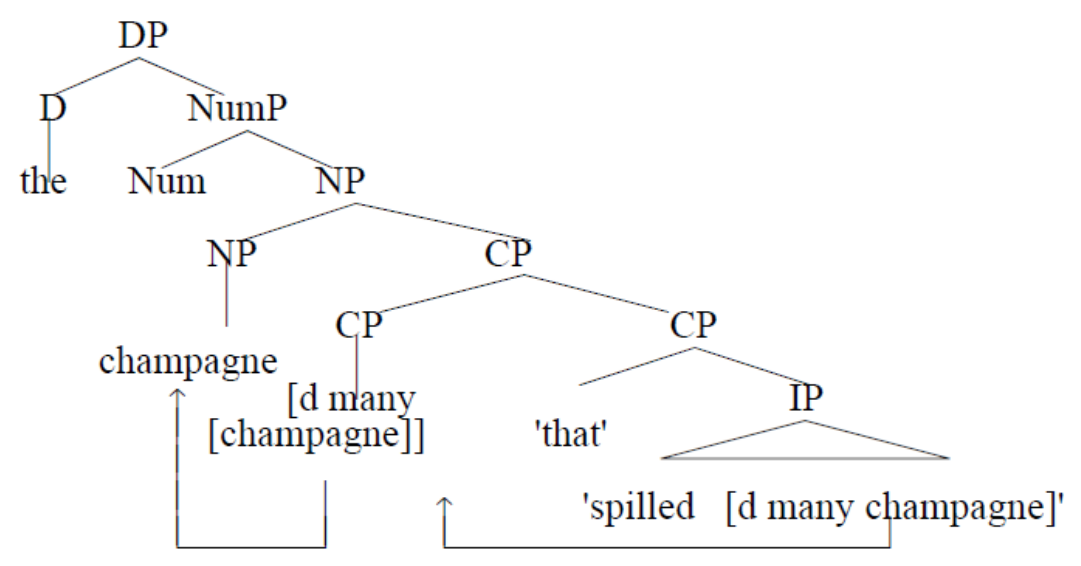

A derivação em (22) aponta que a oração relativa de grau, como ocorre no exemplo (20), também retirado de Szczegielniak (2012), pode estar disponível para interpretação no 
local de reconstrução interna ao CP. Para o autor, a noção de reconstrução relaciona-se diretamente, no caso das relativas, com a leitura podendo ocorrer em seu local de geração, assim, o nome relativizado é linearizado externo ao $\mathrm{CP}$, mas interpretado no interior da relativa, como apresentado. Para o autor, não somente o nome é entendido nessa posição interna ao CP, ocorrendo, também, a percepção da relação de maximalização. Nesse caso, a reconstrução é entendida, seguindo Salzmann (2006), para quem a reconstrução ocorre sempre dentro de uma cadeia de movimento, como uma reconstrução licenciada pela cadeia de movimento do DegP.

Entende-se, então, que o elemento passa de uma posição mais baixa para outra, mais alta, e pode ser interpretada na posição mais baixa, em que deixa um vestígio/cópia. $\mathrm{Na}$ derivação, em (22), isso pode ser entendido pelo fato do nome "champagne" ser interpretado no interior da relativa, fator que causa a maximalização, na visão de Grosu \& Landman (1998).

Para o autor, a teoria do movimento ${ }^{17}$ não consegue abarcar a relação de quantificação apresentada pelas relativas em questão. Szczegielniak (2012), então, postula que a derivação das relativas deve envolver duas relações distintas: a relação de movimento do DegP, como dito anteriormente, em sintaxe aberta; e o nome cabeça sendo movido via matching entendido como a necessidade de compatibilização de traços - com a geração de uma cópia no interior da relativa, permitindo, ainda que após o apagamento, a leitura em sua posição de base, essencial para a geração da leitura maximalizadora.

\footnotetext{
17 A teoria de movimento por vestígio, segundo Nunes (2003), ocorre pela possibilidade de movimento de elementos sintáticos das línguas naturais. Tal operação ocorre, segundo o autor (2003, p. 206), "por meio de uma operação de movimento que procede da seguinte maneira: dada uma configuração estrutural, um objeto sintático se move para uma posição diferente para satisfazer certas condições gramaticais de boa formação de sentenças, deixando em sua posição original um vestígio co-indexado. Um vestígio é uma categoria sintática sem realização fonética que possui as propriedades relevantes para a interpretação apropriada do elemento movido". Ainda segundo Nunes (2003), a teoria do movimento por vestígio é substituída pela teoria de "movimento por cópia", postulada por Chomsky (1993), e apresenta a ideia de que um vestígio é uma cópia de um elemento movido que será apagada do componente fonológico, para evitar a agramaticalidade, mas estará disponível no componente lógico para interpretação. Para Nunes (2003, p. 210), "a operação Mover (por cópia) é composta por quatro suboperações: (i) copiar; (ii) conectar; (iii) formar cadeia; e (iv) apagar vestígio”.
} 
(23) Derivação em Szczegielniak (2012, p. 262).

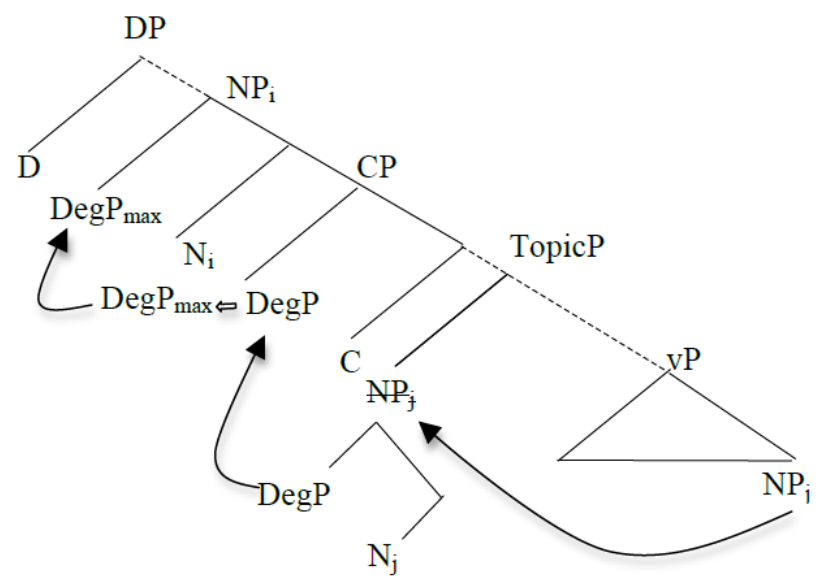

Segundo Szczegielniak (2012, p. 261), the derivation involves DegP being generated in Spec-NPj and raising with the whole NP to a Spec-Topic position in order to license subsequente ellipsis of the inner NP, making NP deletion under identity of form of Topic drop. ${ }^{18}$ Para o autor, a derivação apresentada em (23) demonstra o movimento do NP que contém o DegP para que possa receber a leitura de maximalização. $\mathrm{O}$ autor ainda aponta que o movimento, como representado, é o responsável pela leitura maximalizadora do nome relativizado.

O NP-interno, na visão do autor, não pousa em posição externa ao $\mathrm{CP}$, mas é gerada uma cópia desse NP na posição externa, onde será pronunciado, sendo a cópia interna apagada em PF para evitar a agramaticalidade da sentença. Segundo o autor, esse apagamento se dá sob identidade e permite a leitura de quantificação necessária.

Para Szczegielniak (2012), essa é a principal explicação para a impossibilidade de enumeração das orações de grau, todas maximalizadoras. Para o autor, essa impossibilidade de enumeração é explicada pela possibilidade de merge ocorrer somente entre DegP e nome relativizado. Tal requerimento sintático, na visão do autor, força o $1-1$ matching entre o nome cabeça e seu CP-modificador. Entendemos o 1 - 1 matching como a possibilidade de somente uma relativa de grau poder ligar-se a um único nome.

\footnotetext{
18 “A derivação envolve um DegP gerado em Spec-NPj e alçado, com todo NP, para a posição de Spec-Topic, licenciando elipse subsequente a todo NP, deletando-o em seguida" (tradução livre).
} 


\subsection{Conclusões parciais}

Nesta seção, analisamos as classificações semânticas atribuídas, tradicionalmente, às orações relativas, a saber, a classificação restritiva e a apositiva. De forma geral, a análise da classificação semântica das orações relativas é feita a partir da ideia de denotação de dois conjuntos, como vimos: um conjunto representado pelo nome relativizado, também chamado de nome cabeça; e o conjunto representado pela oração relativa. A forma de relação estabelecida entre esses dois conjuntos resultará na classificação semântica das relativas.

Assim, quando há coincidência entre os conjuntos denotados, ou seja, se os conjuntos apresentam-se como iguais, há a leitura apositiva, entendida como uma explicação dada acerca do nome relativizado, daí o nome relacionado ao aposto, função sintática responsável pela explicação. Por outro lado, quando se estabelece uma relação de intersecção entre os conjuntos, ou seja, o conjunto denotado pela relativa apresenta uma particularização do conjunto maior, representado pelo nome relativizado, há a leitura restritiva.

No caso das relativas de grau, objeto de estudo desta dissertação, a classificação, feita tradicionalmente como restritiva, com leitura de intersecção entre os conjuntos denotados pela relativa e pelo nome cabeça, não nos parece suficiente para demonstrar a relação semântica estabelecida entre os já referidos nome relativizado e relativa, assim, adotamos a ideia de que tais relações são, na realidade, orações com leitura maximalizadora, apresentando uma relação de gradação entre a relativa e o nome relativizado.

De forma geral, as relativas de grau apresentam a leitura maximalizadora, que, segundo Grosu \& Landman (1998), representará um conjunto que indica a leitura máxima do nome relativizado, ou seja, no caso dessas relativas, todas as relativas de grau, há uma leitura de totalidade. Essa leitura de totalidade, a nosso ver, é resultado de uma leitura de grau, gerada a partir da inserção de um sintagma de grau - DegP -, que, ao ser movido durante a derivação, permite a leitura interna à relativa, causando a interpretação de gradação.

Para a identificação de tal leitura, propomos, aqui, a aplicação de um teste no qual o quantificador universal "todos" é acrescido ao nome relativizado, apresentando a leitura de maximalização do nome ao qual se liga. Negrão (1992) utiliza o mesmo teste para discutir a necessidade de determinantes universais na construção de relativas restritivas, com impossibilidade de ocorrência em apositivas, como apresentado nesse capítulo.

Assim, a paráfrase com a aplicação do [todos], quando gera a mesma leitura, permite a comprovação de que há uma leitura quantificadora, visto termos, na oração relativa uma 
relativa existencial, e, consequentemente, de maximalização. Assim, em (24a), temos a relativa de grau, parafraseada em $(24 b)$.

(24) a. Eles levaram consigo as provas que estavam sobre a mesa.

b. Eles levaram consigo todas as provas que estavam sobre a mesa.

Percebe-se, em (24), que a leitura apresentada pelas duas opções de enunciados é exatamente a mesma: nos dois casos, as provas que havia sobre a mesa foram levadas, sem que haja a leitura de que, no universo do discurso, havia outras provas em outros locais que não foram levadas. Na verdade, percebe-se que, neste caso, importam as provas que havia sobre a mesa e que, segundo o enunciado, foram todas levadas.

Além disso, adotamos a ideia de que as relativas, para se realizarem como relativas de grau, precisam apresentar um artigo definido ou um universal, como postulam Grosu \& Landman (1998), Grosu (2002) e De Vries (2002). É o que se pode observar em orações como a encontrada no exemplo (23), retirada de De Vries (2002, p. 25), em que há uma leitura de quantificação máxima.

(25) I looked at the mice that there were [d many mice] in the cage.

'Eu olhei para os ratos que havia/estavam [d many ratos] na gaiola'.

Acerca do exemplo (25), De Vries (2002) postula que, com a ocorrência do artigo definido, não há como a interpretação não ser a de totalidade. Independente do número de ratos que estavam na gaiola, o olhar foi direcionado a todos, com uma contagem máxima. $\mathrm{O}$ nome, com a apresentação do artigo, apresenta-se plural, com valor de todos os ratos que havia na gaiola. Segundo o autor, a leitura de maximalização é possível pela aplicação do sintagma de grau, representado por [d many ratos], apagado foneticamente no momento de Spell-out, para não haver agramaticalidade do enunciado.

Aplicando o teste proposto por nós neste trabalho, o que propõe o acréscimo do quantificador "todos", encontramos a mesma leitura do exemplo (25).

(26) Eu olhei para todos os ratos que havia/estavam na gaiola. 
Dessa maneira, percebe-se que a leitura de maximalização, aqui aplicada às relativas de grau do português, em especial o brasileiro, é uma alternativa mais próxima da necessidade de interpretação desse tipo de enunciado. 


\section{CAPÍtULO 5}

\section{CONSIDERAÇÕES FINAIS E PERSPECTIVAS DE UMA ANÁLISE SINTÁTICA PARA AS RELATIVAS DE GRAU}

Neste trabalho, analisamos a classe formada pelas orações relativas de grau, compostas, a nosso ver, pelas orações relativas de quantidade e pelas relativas existenciais. Ambas, semanticamente, apresentam a mesma leitura, a de quantificação máxima, aqui chamada de "maximalização". Argumentamos, neste trabalho, que, essa conclusão, apresentada por Grosu \& Landman (1998) e Grosu (2002), para as relativas existenciais e de quantidade do inglês, pode também ser aplicada ao PB.

Assim, defendemos que, no português brasileiro, tanto as relativas de quantidade quanto as existenciais apresentam a leitura maximalizadora, que denota o grau máximo do nome relativizado. Até o momento, a maior parte das análises para as relativas de grau tem se concentrado na sua semântica, carecendo de maiores esforços no sentido de se fornecer a formalização de sua sintaxe.

Dessa forma, este trabalho, inicialmente, visa a levantar questionamentos que poderiam direcionar uma análise da sintaxe das relativas de grau, por meio da formalização da derivação apresentada por tais orações. Tal formalização carece de empenho e tempo para ser desenvolvida e, por isso, será ela - a compreensão de como tal formalização pode ser construída - a motivação para a continuidade de nossa pesquisa, que buscará postular tal análise a partir do trabalho aqui iniciado.

Tradicionalmente, as relativas de grau, aqui interpretadas como maximalizadoras, são classificadas semanticamente como relativas restritivas, leitura que apresenta, como visto anteriormente, uma intersecção entre dois conjuntos, um denotado pelo nome relativizado e outro denotado pela oração relativa. A nosso ver, assim como para Grosu \& Landman (1998) e, essa leitura é equivocada, visto que a relação estabelecida entre o nome relativizado e a oração relativa vai além da intersecção entre os conjuntos, por haver uma leitura de maximalização do nome relativizado. É o que se pode perceber no exemplo (1), a seguir.

(1) João organizou os quadros [que havia no escritório]. 
Em (1), percebe-se que a relativa [que havia no escritório] relaciona-se com o DP [os quadros] não por meio de uma intersecção, ou seja, a leitura possível da relação entre eles não pode ser a de que, no universo do discurso, há outros quadros além daqueles que foram organizados por João, típica das relativas restritivas. A leitura possível é a de totalidade; assim, todos os quadros que estavam no escritório foram organizados por João, sem que houvesse outros quadros no universo do discurso. Essa leitura seria proporcionada pelo sintagma de grau - DegP - que nasceria no interior da relativa e de onde o nome relativizado é retirado, chegando, após movimentos cíclicos, à posição de Spec-DP, como representado, em (2), a partir de derivação baseada em Grosu \& Landman (1998) e Szczegielniak (2012). Vale destacar que (2) é a proposta de derivação do exemplo trazido em (1).

(2) [IP João organizou] [DP [D OS] [NP quadros][CP [NP ŁDegP- $d$ many quadros] [CP [C que [IP [Degp d many quadres] havia no escritório]]]]]]

Em (2), acima, percebe-se que o DegP [d many quadros] é gerado no interior do CPrelativo, contendo o nome que será relativizado, no caso, "quadros". De sua posição de base, o DegP é movido para Spec-NP, posição da qual será retirado o nome a ser relativizado, para Spec-DP. Segundo postulação dos autores, esse DegP é foneticamente nulo, para que não haja crash da derivação em PF. Em (2), temos uma relativa existencial, entendida como maximalizadora. No exemplo (3b), a seguir, temos uma relativa de quantidade, derivada da mesma forma que (2), ainda seguindo Grosu \& Landman (1998) e Szczegielniak (2012).

a. $\mathrm{O}$ estudante comprou as apostilas que tinha encomendado.

b. [IP $\mathrm{O}$ estudante comprou] [DP [D as] [NP apostilas][CP [NP EDegP-d many apostilas] [CP [C que [IP [Degpd many apostilas] tinha encomendado]]]]]]

No exemplo (3), acima, encontramos uma relativa de quantidade, que apresenta a quantidade de livros que foram comprados pelo estudante. No caso, a leitura de maximalização pode ser considerada a mesma que a apresentada em (2), apesar de, segundo Móia (2013), não termos, como informação relevante, a identificação da substância envolvida para que tenhamos a leitura quantificadora. Seguindo teste proposto por Móia (2013) para a identificação das relativas de quantidade, (3) pode ser parafraseado com o hiperônimo "a 
quantidade de", inserido antes do nome relativizado, demonstrando tratar-se de uma relativa de quantidade, como em (3').

(3') O estudante comprou a quantidade de apostilas que tinha encomendado.

Vale ressaltar que a leitura, em (3), pode ser referencial, apontando para a ideia de restrição, em que haveria uma intersecção entre o conjunto denotado pelo nome relativizado "apostilas" e as que tinham sido reservadas. Com a paráfrase em (3'), a leitura não pode ser referencial, sendo exclusivamente de quantidade. A nosso ver, tal quantificação indica maximalização do nome "apostilas".

Assim, percebe-se que as relativas de quantidade e as relativas existenciais, apesar da leitura de grau, comum às duas classificações de relativas, apresentam leitura distinta quanto ao nome relativizado. Como dito, argumentamos que o grupo das relativas de grau seria formado por duas subclassificações com diferentes leituras: as relativas de quantidade e as relativas existenciais, apresentadas nos exemplos anteriores. Seguindo Móia (2013) e McNally (2008), e partindo da análise semântica das duas classes de relativas, entendemos que essas duas subcategorias de relativas apresentam características distintas e comuns, permitindo, então, que sejam subclassificações de uma classe maior, as relativas de grau.

Assim, entende-se que as características distintivas dessas duas classes de relativas podem ser assim resumidas: as relativas de quantidade apresentam leitura quantificadora do nome relativizado, enquanto as existenciais apresentam uma estrutura específica, com um verbo que denota a existência do nome relativizado, a substância desse nome e também uma quantificação máxima dele, como é possível observar nos exemplos apresentados a seguir.

(4) Perdemos a batalha porque não tínhamos, nem de perto nem de longe, os soldados que o inimigo tinha. (Móia, 2013, p. 473)

(5) O menino derramou a água que estava no copo do professor. (G\&L, 1998, p. 128)

Em (4), percebe-se a ocorrência de uma relativa de quantidade, seguindo Móia (2013), uma vez que a oração deve ser lida como a quantificação do nome relativizado, apresentando, nas palavras do autor, "a quantidade de soldados que o inimigo tinha", em sua totalidade, claro, mas sem que a identificação da substância do nome relativizado seja a informação mais relevante, não sendo, assim, necessário identificar-se tal substância. A inserção da expressão 
“a quantidade de", como percebe-se em (3'), antes do nome relativizado, é uma das estratégias apresentadas pelo autor para a identificação desse tipo de oração.

Móia (2013) entende que tal expressão está subentendida à esquerda do nome relativizado. Ainda segundo o autor, a predicação envolvida não se relaciona com os indivíduos ou a substância do nome relativizado, denotando, somente a quantidade envolvida. Como dito anteriormente, entendemos essa identificação de quantificação como uma leitura de grau, de quantificação máxima.

Por sua vez, em (5), percebe-se que a relativa é uma oração existencial, visto apresentar, seguindo Foltran (1998), uma estrutura específica. Nesse caso, um verbo existencial dentro do contexto apresentado, o "estar", e um elemento locativo posposto ao verbo. Acerca da leitura dessas relativas, nota-se que elas apresentam a noção de existência do nome relativizado, bem como sua quantificação, também de forma maximalizadora.

Dessa forma, entendemos que há diferenças entre as relativas de quantidade e as relativas existenciais, que apresentam, como ponto de convergência, a leitura de quantificação máxima, fato que as coloca no grupo das relativas de grau. De maneira resumida, é possível entender, então, que as orações relativas de quantidade apresentam entendimento exclusivo da quantidade envolvida na leitura do nome relativizado, enquanto as existenciais apresentam leitura de quantidade, mas, também, identificam a substância do nome relativizado. Por outro lado, reforça-se a ideia de que, ambas, apresentam uma leitura de quantificação máxima do nome relativizado, interessando-nos como problemas surgidos da análise dessas relativas.

Tomando como pressuposto a ideia de que as relativas de grau apresentam uma derivação que confere, ao nome maximalizado, esse valor, surge uma problematização com relação à análise dessas relativas, uma vez que nos interessam, para a análise desse tipo de relativas, as características que as diferem, bem como a característica que as aproxima, carecendo de entendimento os mecanismos sintáticos que permitem esse tipo de leitura ao mesmo tempo distinta e igual.

Como dito anteriormente, seguimos Móia (2013) e McNally (2008) na postulação de que as relativas de quantidade e as relativas existenciais formam dois grupos distintos, ainda que apresentem leitura de quantificação máxima. Assim, intriga-nos a ideia de que as duas relativas apresentem duas possibilidades de leitura. De que maneira essas orações apresentam quantificação máxima com relação ao nome relativizado, ao mesmo tempo em que, em um 
caso, identifica somente sua quantidade, enquanto, em outro, apresenta leitura de quantidade e da substância envolvida?

Partindo da leitura de maximalização, apresentada para as duas relativas, percebe-se um fato interessante na análise apresentada por Grosu (2002). As relativas maximalizadoras, entendidas pelo autor como todas as relativas de grau, são derivadas por meio da adição de uma relação de traços semânticos. Na visão do autor, o traço semântico [DET] é adicionado à relativa, no momento da derivação, fazendo com que essa oração passe a ter valor de quantificação universal. Essa formação carece, a nosso ver, do desenvolvimento de uma formalização de derivação que explique a forma como esses traços são introduzidos e como são interpretados na sintaxe, trazendo, inicialmente, a diferença entre as relativas restritivas e as maximalizadoras que, como entende a linguística tradicional, devem receber leitura de intersecção de conjuntos.

Partindo do pressuposto defendido por Chomsky (1995), os movimentos são motivados pela necessidade de checagem de traços, ainda que tais traços possam ser checados/valorados, no atual estágio do Programa Minimalista, por Agree ou à distância. A necessidade de checagem de traços, então, pode ser uma explicação para a necessidade de movimento do sintagma de grau que aplicará, na visão de Grosu (2002), a atribuição de leitura quantificadora máxima ao nome relativizado, com o qual se relaciona. Assim, na continuação desta pesquisa, buscaremos a postulação de uma formalização de derivação específica para as relativas de grau, levando em conta a checagem de traços como uma possível motivação para o movimento do DegP envolvido no processo de relativização de grau. Além disso, buscaremos analisar a posição em que esse DegP será mergido, podendo ele ser gerado já na posição em que terá escopo sobre uma determinada projeção, na derivação das relativas de grau.

A diferença de posição de merge que tal sintagma de grau pode apresentar influência diretamente na relação de c-comando que estabelecerá com o elemento ao qual será concatenado sintaticamente, influenciando, então, no escopo desse sintagma e, consequentemente, na leitura apresentada pela relativa.

Assim, tanto para Grosu \& Landman (1998) quanto para Szczegielniak (2012), a relação de maximalização das relativas de grau ocorre pela existência, no interior da derivação, de um sintagma de grau - DegP -, que apresenta uma relação de quantificação máxima com relação ao nome relativizado. Grosu \& Landman (1998) identificam essa relação com a postulação de um sintagma $[d$ many $x$ ] sendo gerado no interior da relativa e movido, 
em seguida, para Spec-CP, de onde o nome $x$ será movido para a posição de Spec-DP já na oração matriz. Nessa expressão de grau, os autores indicam que o índice $d$ representa a soma de todas as quantidades, indicando a maximalização da leitura; many indica a quantificação do nome relativizado, que é representado pelo índice $x$. É o que se percebe nos exemplos (6) e (7), a seguir, com a derivação dos exemplos (4) e (5), seguindo Grosu \& Landman (1998).

(6) [IP Perdemos a batalha porque não tínhamos, nem de perto nem de longe, [DP [D Os] [NP soldados][CP [NP ŁDegP- $d$ many soldados] [CP [C que [IP o inimigo tinha [DegP- $d$ many soldados]]]]]]]].

(7) [IP $\mathrm{O}$ menino derramou [DP [D a] [NP água][CP [NP ŁDegp-d many água] [CP [C que [IP [Degp-d many água] estava no copo do professor]]]]]]].

Para Szczegielniak (2012), o DegP, responsável pela quantificação do nome relativizado, também seria gerado no interior da relativa e, em seguida, seria movido como a expressão indicada por Grosu \& Landman (1998), garantindo a leitura de grau do nome relativizado. Assim, percebe-se que a leitura de grau é, para os três autores, resultado da existência desse sintagma de grau, que seria gerado na mesma posição, interna à relativa, para garantir, ali, sua reconstrução de significado. Essa posição de base varia conforme a função desempenhada pelo nome relativizado na relativa, mas, apesar disso, para os autores, o DegP é sempre gerado no interior da relativa, onde será necessariamente interpretado.

Essa postulação, a de que a relação de grau é garantida pelo sintagma de grau, movido para fora do CP-relativo, apresenta uma das possibilidades de entendermos o porquê das duas orações, ainda que diferentes quanto à relação com o nome relativizado, apresentando leitura de quantidade ou de quantidade/substância, poderem apresentar leitura de grau. Ou seja, esse DegP move-se durante o processo de derivação e resulta em uma leitura igual às duas classes de relativas, a leitura de maximalização, ainda que essas relativas tenham, cada oração, uma leitura distinta, as de quantidade, denotando somente a quantidade do nome envolvido na relativização e as existenciais, com a identificação do binômio substância/quantidade.

A partir disso, a leitura diferente apresentada por essas duas subclasses poderia ser explicada pela possibilidade de, para cada uma das subcategorias das relativas, haver um local distinto para o merge do DegP. Assim, nas relativas de quantidade, o DegP seria mergido em uma posição da derivação, enquanto, nas relativas existenciais, essa posição de merge seria diferente, garantindo as leituras diferentes para os nomes, em um caso, exclusiva leitura de 
quantidade e, no outro caso, uma leitura de quantidade somada à substância do nome relativizado.

Dessa forma, se a diferença entre as duas leituras for a posição de merge do DegP, teríamos duas derivações distintas, uma para cada uma dessas relativas. Assim, entenderíamos que o DegP é o mesmo, apresentando-se como responsável pela quantificação máxima do nome relativizado, mas teria posições diferentes de merge. A posição diferente de merge do sintagma de grau seria responsável por relações de c-comando distintas entre as orações que compõem as relativas de grau. Infelizmente, pela brevidade desta pesquisa, não houve possibilidade de postulação das propostas de formalização dessas duas derivações, sendo essas questões a motivação para a continuidade da pesquisa.

A segunda possibilidade de explicação para a existência de duas subclassificações das relativas entendidas como relativas de grau é a relação que se estabeleceria entre o nome relativizado e a predicação do verbo da oração encaixada. Como a leitura de quantidade é comum aos dois tipos de relativa, a diferença de predicação, se houver, seria identificada no comportamento sintático do verbo das relativas existenciais, o qual, por algum motivo, seria capaz de identificar a existência do nome, relacionando-a com a substância do nome.

Os verbos existenciais, para Scherre (2007), apresentam comportamento semelhante ao dos verbos inacusativos, ou seja, os argumentos desses verbos são gerados à direita dos verbos, na posição de argumento interno, recebendo o papel temático de tema. Essa particularidade do verbo existencial, o fato de não gerar um argumento externo, pode ser um fator de influência para a leitura de identidade de substância e de quantidade, visto que a relação estabelecida entre o argumento interno e o verbo é mais complexa e profunda. Assim, se a diferença de leitura não for resultado da posição de merge do sintagma de grau, pode ser resultado de uma relação de predicação diferente entre os verbos utilizados nas relativas de quantidade e existenciais.

Dessa forma, a diferença de leitura entre as relativas de quantidade que, como dito anteriormente, apresentam leitura exclusiva da quantidade do nome relativizado, e as relativas existenciais, que apresentam leitura completa de quantidade e da substância do nome relativizado, seria determinada pela forma como o nome-cabeça, retirado do interior da relativa, estabelece relação com o verbo da relativa.

Entendemos, então, que há um problema na análise das relativas de grau: como é possível explicar, sintaticamente, a relação estabelecida entre as relativas de grau e o nome 
relativizado? Esse problema configura-se a partir da existência de duas leituras atribuídas a um mesmo nome pela relativa de grau: nas relativas de quantidade, há a leitura de grau máximo e a leitura de identificação de quantidade do nome envolvido no processo de relativização; e, nas relativas existenciais, há a leitura de grau máximo e a leitura de identificação de quantidade e de substância do nome relativizado.

Em resumo, essas leituras, a nosso ver, podem apresentar uma de duas explicações. $\mathrm{Na}$ primeira delas, relacionada à derivação das relativas, há posições diferentes para a operação de merge do sintagma de grau - uma para as relativas de quantidade e outra para as relativas existenciais. Na segunda, haveria diferença na predicação dos verbos das duas subclasses das relativas de grau. A leitura de quantidade e substância, nas relativas explicativas, seria fruto de uma característica diferente dos chamados verbos existenciais, ou que ocorrem em contextos existenciais. 


\section{CONCLUSÃO}

Nesta pesquisa, apresentamos uma análise das orações relativas, com ênfase em um subgrupo dessas orações, chamadas "relativas de grau". Tal subgrupo é composto por dois outros tipos de relativas, chamadas relativas de quantidade e relativas existenciais. Nosso objeto de estudo, as relativas, forma um terreno de estudo amplo dentro da linguística, tanto no que diz respeito à sintaxe dessas orações quanto no que tange à sua semântica, ambos explorados no decorrer desta pesquisa. Neste trabalho, analisamos as relativas de grau de uma perspectiva sintático-semântica, uma vez que uma das propostas era a leitura diferenciada desse grupo de orações. A análise do objeto de estudo teve como base os pressupostos da linguística gerativa.

Assim, este trabalho organizou-se buscando apresentar uma visão geral das relativas, não somente as de grau, objeto de estudo desta dissertação. Para tanto, no primeiro capítulo, apresentamos alguns pressupostos gerais da linguística gerativa, bem como um pequeno histórico das fases que essa corrente, surgida na década de 1950, teve até o momento atual, o Programa Minimalista. Neste capítulo, reforçou-se a ideia de que a faculdade da linguagem é um órgão interno ao cérebro/mente do ser humano, formada por características encontradas em todas as línguas, separadas em Princípios e Parâmetros.

No segundo capítulo, por sua vez, foram apresentadas as teorias que analisam essas orações de um ponto de vista puramente sintático, com a análise das propostas Wh-movement, de Chomsky (1977); e Raising, de Kayne (1994). A proposta de Chomsky entende as relativas como orações adjungidas a um DP no interior da matriz, apontando para o movimento do elemento-QU, que teria como posição de base o interior da relativa. A proposta, extremamente importante para a análise das orações relativas, apresentava alguns problemas, como a falta de explicação, pelo modelo, do compartilhamento de traços e o fato desse modelo não abarcar as relativas sem elemento-QU, típicas do inglês.

A segunda proposta apresentada, o modelo Raising, que tem em Kayne seu principal teórico, por sua vez, apresenta a ideia de que a relativa é derivada como complemento do núcleo funcional D, em um DP. Tendo diferenças sintáticas claras com relação ao modelo tradicional, Wh-movement. Dentre as principais diferenças, está a postulação de que o nome relativizado tem seu lugar de base no interior da relativa, sendo alçado, desta posição, para dentro do DP relativizado. 
Percebeu-se, então, que a proposta de Raising atendia de forma mais completa a análise das relativas de grau, uma vez que a leitura maximalizadora está ligada à existência de um determinante, sendo vedada sem que tal determinante ocorra. Assim, se a leitura maximalizadora acontece somente com a ocorrência do determinante, há uma relação mais profunda entre relativa e determinante.

No terceiro capítulo, por sua vez, apresentamos as orações que, a nosso ver, perfazem o grupo das relativas de grau. Tal grupo é formado pelas relativas de quantidade e pelas relativas existenciais. As primeiras, na visão da maior parte dos linguistas, apresenta leitura de identificação de quantidade do nome relativizado. As segundas, existenciais, apresentam uma leitura de quantificação do nome relativizado, bem como, talvez por sua natureza existencial, indica a substância do nome, sendo indissociáveis as informações de quantidade e de substância do nome.

Ainda no terceiro capítulo, foram apresentadas as relativas de grau. Tais relativas têm, em comum, a postulação de uma sintagma de grau - DegP -, responsável por uma leitura de quantificação máxima, universal. É interessante reforçar que, para os teóricos que analisam tais relativas, o DegP seria gerado interno à relativa, de onde o nome relativizado é movido para o domínio do DP que tem o CP-relativo como complemento.

No quarto período, foram analisadas as classificações semânticas tradicionais, a restrição e a explicação, bem como a relação semântica de maximalização, entendida, como dito anteriormente, como a leitura possível das relativas de grau. Assim, percebeu-se que a diferença principal entre as relativas restritivas e apositivas está na disposição dos conjuntos envolvidos no processo de relativização, um denotado pelo nome relativizado e outro pela relativa. Na restrição, como visto, há uma intersecção entre os dois conjuntos, enquanto nas explicativas, os dois conjuntos coincidem, apresentando-se como o mesmo conjunto.

Nas relativas maximalizadoras, classificação das de grau, não há, em jogo, conjuntos a serem comparados, mas sim uma leitura de quantificação com relação ao nome relativizado. Assim, a oração relativa é entendida, em conjunto com o nome relativizado, como uma quantificação máxima do nome, uma leitura de totalidade.

Por fim, no quinto capítulo, apresentamos a problematização que já vinha sendo, ainda que superficialmente, apresentada durante os demais capítulos desta dissertação. Neste último capítulo, apresentamos o problema relacionado à formalização da derivação das relativas de grau que, apesar de apresentarem leitura de quantificação máxima, apresentam, também, 
leituras de quantidade sem identificação da substância envolvida - no caso das relativas de quantidade - e leituras de quantidade com identificação da substância envolvida no nome - no caso das relativas existenciais. Essa diferenças de leitura podem ser resultado de uma posição diferente de merge do DegP, ou de uma relação de escopo diferente em cada uma das relativas, ou, por fim, resultado da predicação dos verbos existenciais, que se comportariam de formas diferentes das outras relativas, as de quantidade.

As respostas aos problemas levantados durante esta dissertação servirão de material de trabalho para a continuidade da pesquisa, que intentará desenvolver uma formalização para a derivação dessas relativas, buscando entender como se dá a leitura diferenciada dessas duas subclasses de relativas. 


\section{Referências Bibliográficas}

AOUN, J. \& LI, A. Essays on the representational and derivational nature of grammar: the diversity of wh-constructions. Disponível na Internet: http://www.usc.edu/dept/LAS/ealc/chinling/aoun_li.htm, 2001.

AUGuSTO, M. R. A., Corrêa, L. M. S \& Marcilese, M. Demandas de processamento distintas na produção de relativas: contribuições para o debate sobre as análises do tipo raising ou matching. Anais do GT da ANPOLL 2010. 2012.

BIANCHI, V. Consequences of Antisymmetry: headed relative clauses. New York: Mouton de Gruyter, 1999.

. Headed relative clauses in generative syntax - Part I. In: Glot International, v. 6, n. 7 , September, 2002, p. 197-204.

Headed relative clauses in generative syntax - Part II. In: Glot International, v. 6, n. 8, September, 2002, p. 197-204.

BORGES NETO, José. O Empreendimento gerativo. In: MUSSALIM, F. \& BENTES, A. C. (Orgs). Introdução à Linguística - Fundamentos Epistemológicos. São Paulo: Cortez, 2005, p. 93-127.

BRAME, M. A new analysis of the relative clause: evidence for an interpretive theory. MIT, Cambridge, Mass, 1968.

BRITO, A. M. \& Duarte, I. Orações relativas e construções aparentadas. In: MATEUS, M. H. et al., Gramática da língua portuguesa (5ª ed.). Lisboa: Caminho, 2003, p. 653-694.

BRITO, A. M. B. de. A sintaxe das orações relativas em Português: estrutura, mecanismos interpretativos e condições sobre a distribuição dos morfemas relativos. Porto: Instituto Nacional de Investigação Científica, 1991.

CARLSON, G. Amount relatives. Language, n. 53, 1977, p. 520-542.

CHOMSKY, Noam. Aspectos da teoria da sintaxe. Coimbra: Arménio Amado, 1965. (Tradução de José Antônio Meireles e Eduardo Paiva Raposo, 1978).

. Remarks on nominalization. In: JACOBS, R. \& ROSENBAUM, P. (org.). Readings in English transformational grammar. Waltham, MA: Blaisdell, 1970, p.184-221.

. Linguística Cartesiana, São Paulo: Edusp, 1972.

. On Wh-Movement. In: CULICOVER, P. WASOW, T. \& AKMAJIAN, A. (eds.).

Formal syntax. NY: Academic Press, 1977.

Lectures on Government and Binding. Dordrecht: Foris, 1981.

Linguagem e mente. Brasília: Ed. UnB, 1998. 
. Derivation by Phase. In Michael Kenstowicz (Ed.). Ken Hale: A Life in Language. Mass.: MIT, 2001, p. 1-54.

. Novos horizontes no estudo da linguagem e da mente. São Paulo: Editora Unesp, 2005.

. Sobre Natureza e Linguagem. São Paulo: Martins Fontes, 2006.

Linguagem e mente. São Paulo: Editora Unesp, 2009.

2014.

CORRÊA, L. M. S.; AUGUSTO, M. R. A.; LONGCHAMPS, J. R.; FORSTER, R. Referência anafórica com relativas restritivas de objeto: custo relativizado na interface gramática-pragmática. Linguística, v. 8, n. 2, 2012, p. 173-196.

FARIA, P. O Axioma da Correspondência Linear e a Estrutura Sintagmática Nua: um levantamento de propostas de compatibilização. Filol. Linguíst. Port., São Paulo, v. 16, n. spe, dez. 2014, p. 261-285.

GROSU, A. \& LANDMAN, F. Strange relatives of the third kind. Natural Language Semantics 6, 1998, p. 125-170.

GROSU, A. Strange relatives at the interface of two millennia. Glot International, v. 6, n. 6, 2002, p. 145-167.

HEIM, I. Where does the definiteness restriction apply? Evidence from the definiteness of variables. In: REULAND, E. \& TER MEULEN, A. G. B. (Eds.) The representation of (in)definiteness. Cambridge, Mass.: MIT Press, 1987, p. 21-42.

KATO, M. Orações relativas: variação universal e variação individual no português. Estudos Linguísticos V, 1981, p. 1-16.

Recontando a história das relativas em uma perspectiva paramétrica. In: I. Roberts; M. Kato (orgs.). Português Brasileiro: uma viagem diacrônica: homenagem a Fernando Tarallo. Campinas, SP: Editora da Unicamp, 1993.

- Teoria sintática: de uma perspectiva de "-ismos" para uma perspectiva de "programas". DELTA [online], vol.13, n. 2, 1997, p. 275-299.

KATO, M. \& NUNES, J. Two Sources for Relative Clause Formation in Brazilian Portuguese. Paper presented at the Eighth Colloquium on Generative Grammar. Universidade de Lisboa, 19-22/4/98, 1998.

KAYNE, R. The antisymmetry of syntax. Cambridge, Mass.: The MIT Press, 1994.

KENEDY, E. Aspectos estruturais da relativização em português: uma análise baseada no modelo raising. RJ: UFRJ, Dissertação de Mestrado, 2003. 
. O modelo raising de descrição de cláusulas relativas: evidências do português. Revista da ABRALIN, Santa Catarina, v. II, 2005, p. 9-22.

A Antinaturalidade de Pied-Piping em Orações Relativas. RJ: UFRJ, Tese de Doutorado, 2007a.

- Raising como uma nova descrição sintática para as orações relativas. Linguística (PPGL/UFRJ), v. 3, 2007b, p. 197-216.

. Gerativismo. In: Martelotta M. E. T. (Org.). Manual de linguística. São Paulo: Contexto, v. 1, 2008, p. 127-140.

. Curso básico de linguística gerativa. São Paulo: Contexto, 2013.

. Estruturas Sintáticas de Orações Relativas. In: BISPO, E. B. \& DE OLIVEIRA, M. R. (Orgs.) Orações relativas no português brasileiro: diferentes perspectivas. Niterói: Editora da UFF, 2014.

LESSA-DE-OLIVEIRA, A. Orações Relativas do Português: questões teóricas e fatos de aquisição. Tese de Doutorado, Unicamp, Campinas-SP, 2008.

MARCHESAN, A. C. As Relativas Livres em Português Brasileiro e os Requerimentos de Compatibilidade. Universidade Federal de Santa Catarina, Florianópolis, Dissertação de Mestrado, 2008.

. As Relativas Livres no Português Brasileiro. Universidade Federal de Santa Catarina, Florianópolis, Tese de Doutorado, 2012.

Da MATTA, S. S. Um estudo sobre a compreensão de orações relativas com crianças em idade escolar. Universidade Federal do Paraná, Curitiba, Dissertação de Mestrado, 1999.

McNALLY, L. DP-Internal only, amount relatives, and relatives our of existentials. Linguistic Inquiry. v. 39, n. 1, 2008, p. 161-169. Disponível em: <http://www.upf.edu/pdi/louisemcnally/_pdf/publications/McNally_amtrels.pdf >. Acesso em: 14 de abril de 2015.

prelo)

Existential Sentences Cross-Linguistically: Variations in Form and Meaning. (No

MEDEIROS JUNIOR, P. Sobre sintagmas-Qu e Relativas Livres no Português. UnB, Brasília-DF, Dissertação de Mestrado, 2005.

. Orações relativas livres do PB: sintaxe, semântica e diacronia. Unicamp, CampinasSP, Tese de doutorado, 2014.

MILSARK, Gary. Existential Sentences in English. PhD. Dissertation. MIT, Cambridge, MA, 1974.

MIOTO, C. As Interrogativas no Português Brasileiro e o Critério WH. Letras de Hoje. Porto Alegre. V. 29, n. 2, 1994, p. 19-33. 
MIOTO, C.; FIGUEIREDO SILVA, M. C.; LOPES, R. Novo manual de sintaxe. $3^{\mathrm{a}}$ ed. Florianópolis: Insular, 2007.

MÓIA, T. Orações relativas de quantidade e quantificadores implícitos. Textos Selecionados, XXVIII Encontro Nacional da Associação Portuguesa de Linguística. Coimbra, APL, 2013, p. 473-492.

NUNES, Jairo. Explorando a Teoria de Movimento por Cópia no Programa Minimalista. In: E. Albano et al. (orgs.): Saudades da Língua. Mercado de Letras: 2003, p. 273-284.

SCHMITT, C. Some consequences of the complement analysis for relative clauses, demonstratives and the wrong adjectives. In: ALEXIADOU et al. The syntax of relative clause. Amsterdam and Philadelphia: John Benjamins, 2000, p. 309-348.

SELLS, P. Restrictive e Non-restrictive modification. Report\#CSLI-85-28. Stanford:Stanford University. 1985.

SMITH,C. Determiners and relative clauses in a Generative Grammar of English. Language 40, 1964.

SZCZEGIELNIAK, A. Degree phrase raising in relative clauses. In: Camacho-Taboada, Victoria, Ángel L. Jiménez-Fernández, Javier Martín-González and Mariano ReyesTejedor (Eds.) Information Structure and Agreement. vi, 376, 2013, p. 255-274.

TARALLO, F. Relativization Strategies in Brazilian Portuguese. University of Pennsylvania, PHD. Dissertation, 1983.

VALER, S. As sentenças relativas com núcleo nominal nos dados de fala (projeto Varsul) de Florianópolis. UFSC, Florianópolis, Dissertação de Mestrado. 2008.

VERGNAUD, J. R. French Relative Clauses. Doctoral Dissertation, MIT, 1974.

DE VRIES, M. The Syntax of Relativization. Utrecht: Lot, 2002.

The syntax of appositive relativization: On specifying coordination, false free relatives, and promotion. Linguistic Inquiry 37: 2006, p. 229-270. 